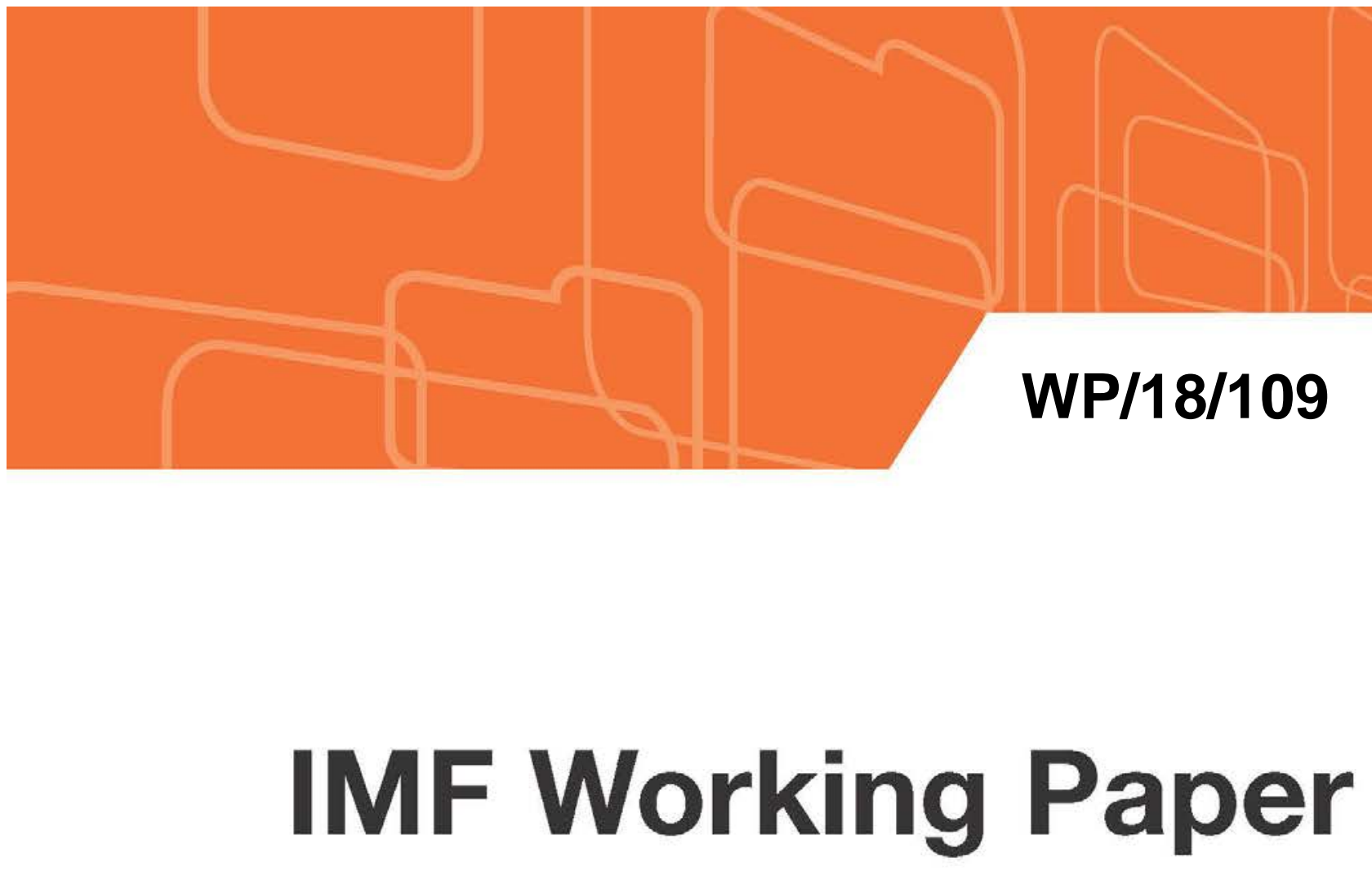

\title{
Peeling Away the Layers: Impacts of Durable Tariff Elimination
}

by Arevik Gnutzmann-Mkrtchyan and Christian Henn

IMF Working Papers describe research in progress by the author(s) and are published to elicit comments and to encourage debate. The views expressed in IMF Working Papers are those of the author(s) and do not necessarily represent the views of the IMF, its Executive Board, or IMF management.

$$
\text { I N T E R N A T I O N A L M O N E T A R Y F U N D }
$$




\title{
IMF Working Paper
}

European Department

\section{Peeling Away the Layers: Impacts of Durable Tariff Elimination Prepared by Arevik Gnutzmann-Mkrtchyan* and Christina Henn ${ }^{1}$}

\author{
Authorized for distribution by Craig Beaumont
}

May 2018

\begin{abstract}
IMF Working Papers describe research in progress by the author(s) and are published to elicit comments and to encourage debate. The views expressed in IMF Working Papers are those of the author(s) and do not necessarily represent the views of the IMF, its Executive Board, or IMF management.
\end{abstract}

\begin{abstract}
We demonstrate that durable MFN tariff elimination affects trade patterns through several layers, which generates non-linear impacts. First, complete tariff elimination results in a large additional trade gains over and above tariff reductions. Second, commitment to durable tariff elimination, through WTO bindings, further boosts both imports and exports of ITA members. The unique setting of the WTO Information Technology Agreement (ITA) allows us to identify these effects of non-discriminatory trade policies because (i) ITA constitutes a quasi-natural experiment as several "passive" signatories joined it as an unavoidable part of pursuing of a larger policy objective, and (ii) ITA's partial coverage of the IT sector provides a natural control group for cross-product identification. Commitments under the ITA spurned development of a downstream IT export sector in "passive” signatories.
\end{abstract}

JEL Classification Numbers: F13, F14, F15, L63

Keywords: Non-discriminatory Trade Policies, MFN Tariff Elimination, World Trade Organization, Information Technology Agreement, Trade Policy Certainty, Global Value Chains, Product-Level Data.

Author’s E-Mail Address: mkrtchyan@mak.uni-hannover.de and chenn@imf.org

\footnotetext{
${ }^{1}$ We thank WTO delegations and secretariat staff, in particular Florian Eberth, Rainer Lanz, and Roy Santana, for assistance with ITA membership and product classification, and Timothy Sturgeon for kindly sharing his intermediate/final goods classification. We also thank Marc Bacchetta, Cosimo Beverelli, Theo S. Eicher, Hinnerk Gnutzmann, Jasmin Groeschl, Paulo Guimaraes, Inmaculada Martinez-Zarzoso, Alberto Osnago, Chris Papageorgiou, Roberta Piermartini, Xiaobing Tang, Robert Teh, Yoto Yotov, and participants at several seminars for suggestions. Early work on this paper was undertaken while both authors were at the WTO. The views expressed in this paper are those of the authors and do not represent the position of the WTO or its Members. Arevik Gnutzmann-Mkrtchyan gratefully acknowledges funding support received from the ITTC Support Programme for Doctoral Studies at the WTO. Any remaining errors are responsibility of the authors.

* Corresponding author: Arevik Gnutzman, Leibniz University of Hanover
} 


\section{Introduction}

When the issue of trade policy comes up, tariffs spring to most people's minds. However, the most wide-ranging and durable elimination of tariffs - on a Most-favoured-nation (MFN) treatment basis through World Trade Organization (WTO) tariff bindings - has been studied comparatively little. Recent empirical trade literature mainly focusses on non-tariff measures and discriminatory trade policies, notably preferential trade agreements. Alongside only few other papers, this one reemphasizes how important tariffs are. ${ }^{1}$ We find that trade increases substantially after permanent non-discriminatory tariff elimination through quite novel nonlinear effects.

We study the WTO Information Technology Agreement (ITA). It is the sole example of an agreement that has instituted MFN tariff elimination on a near-global basis for a substantial number of products. Identification - which is often more challenging for non-discriminatory than discriminatory trade policies - is facilitated through six unique characteristics of the ITA. ${ }^{2}$ A crucial one is that the ITA was limited to about half of all IT products, allowing us to use non-eligible products as a natural control group. A second crucial characteristic is that many countries signed up to ITA as an unavoidable part of pursuing a larger policy objective, such as WTO membership, European Union (EU) accession or a Free Trade Agreement with United States (U.S.); this largely exogenous selection limits any endogeneity concerns. ${ }^{3}$

It is important in our view to reinforce the study of impacts of MFN tariff liberalization in light of important policy implications. First, tariffs remain at moderately high levels in many emerging and developing countries. Second, what's being left on the negotiating table is sizable: MFN tariff elimination has large effects, as shown here. Third, there might be more promise in the WTO to finish the tractable tariff agenda - despite long-standing stalemates - than to make substantial inroads into complex non-tariff measures (NTMs). We therefore agree with Bagwell et al. (2016) that the WTO not at all passé; our results provide more evidence that it is important to revive its negotiating function. The time window to do so could also be closing. Antràs and Staiger (2012) emphasize that multilateral negotiations may become more difficult as offshoring deepens. Ironically, our results imply that offshoring was boosted in the first place by past multilateral negotiation success. Fourth, it is important to contain populist backlash against trade liberalization. Reversing previously achieved tariff elimination could imply that our sizable effects work damagingly in reverse.

Our paper advances the empirical literatures on non-discriminatory trade policy changes, WTO trade effects, and trade policy certainty; it also adds to the literature on international production sharing, and a small literature on the ITA. ${ }^{4}$ Our contribution is threefold.

\footnotetext{
${ }^{1}$ Notable other papers are Caliendo et al. (2015) and Heid et al. (2017); see Section 2.

${ }^{2}$ Section 2 elaborates on the challenges and Section 3.1 on how the ITA manages to address these.

${ }^{3}$ Section 3.1 presents the list of these countries that joined ITA as a consequence of a larger policy objective; Annex I provides evidence for the grouping of a subset of late ITA joiners as exogenous.

${ }^{4}$ Section 2 elaborates.
} 
First, our paper demonstrates that MFN tariff elimination generates deep and nonlinear impacts through four channels, or "layers". MFN tariff reduction itself only has a moderate positive impact on imports, with a percentage point decrease in tariffs raising import value by 0.7 percent. But a second, nonlinear, gain is realized if a tariff is lowered all the way to zero. We estimate this tariff elimination effect to increase imports by 13 percent within a broad machinery control sector, which constitutes one third of world trade. We argue, based on the border administration literature, that this likely results from risk-based systems in customs, which select shipments less frequently for (rigorous) inspection if they are subject to zero MFN tariffs. ${ }^{5}$ This reduces traders' time and administrative costs of customs clearance. ${ }^{6}$ Third, we show that the perceived durability of liberalization through WTO tariff bindings under the ITA fosters "commitment" effects on imports - and fourth - on exports. The latter one for exports illustrates that certainty of import availability can support export sectors. To our knowledge, both the tariff eliminination effect and the commitment effect for exports have not been appreciated in previous gravity literature.

Second, our paper illustrates that durable MFN tariff elimination increases fragmentation of production. There are important differences in how intermediate and final goods trade responded across countries: ITA accession spurred specialization of developed countries in upstream intermediate production while emerging country members integrated downstream. Also, the tariff elimination effect is larger for intermediate goods, as should be expected in global value chains (GVC) wherein these goods often cross borders several times. ${ }^{7}$

Third, the ITA benefited a subgroup of largely developing and emerging countries' exports the most, which joined the ITA after inception as an unavoidable by-product in the pursuit of a larger policy objective. We document that this constitutes a quasi-natural experiment, which can allay endogeneity concerns. Several of these countries, to which we refer as passive signatories, were quite skeptical of the ITA. Nonetheless, they reaped larger trade benefits than other ITA members, to which we refer as active signatories. The commitment effects on the import and export sides, when taken together, show that the ITA helped turn them into downstream IT exporters. ITA accession boosted their final goods exports by some 26-40 percent, as illustrated by the commitment effect on exports. ${ }^{8}$ To facilitate this export expansion, they relied on ITA intermediate goods imports. These rose by 26-60 percent relative to other information and communication technology (ICT) and machinery products

\footnotetext{
${ }^{5}$ Section 5.3 elaborates.

${ }^{6}$ A related "time in trade" literature finds that trade flows decrease considerably if time is lost in transit (e.g., Djankov et al., 2010; Hummels and Schaur, 2013; Martincus et al., 2015).

${ }^{7}$ Figure C.5 in WTO (2014) presents a GVC participation index for 30 economies where the share of goods that cross borders in the production prodcess at least twice was ranging between 37 percent to more than 70 percent.

${ }^{8}$ This large effect comes in addition to increases already implied by lower tariffs in destination countries, including in active signatories, and helps resolve a dispute in earlier literature. Joseph and Parayil (2006) hypothesized that countries joining ITA after its inception would reap lower benefits given that they could not bring their own interests to bear in the negotiations. In contrast, Anderson and Mohs (2010), benefiting from more extended time coverage, argue - in line with our results - that the ITA underpinned the rapid increases observed in developing countries' exports.
} 
after ITA accession, as illustrated by the importer commitment effects.

The remainder of the paper is structured as follows. Section 2 discusses related literature. Section 3 lists the ITA's six favorable characteristics for identification, alongside relevant background on the agreement itself. This section also presents initial graphical analyses of the ITA's trade impact in active and passive signatories. Section 4 describes our dataset and Section 5 the estimation strategy employing a structural gravity model and high-dimensional fixed effects to address unobservable characteristics and several endogeneity concerns. This section also discusses key econometric concerns and how characteristics of the ITA help alleviate endogeneity (and other) concerns. Section 6 presents our baseline results. Section 7 (and the Appendix) present extensions and robustness checks that further address endogeneity and identification concerns. Section 8 concludes.

\section{Relation to previous literature}

Our work contributes to four strands of literature.

First, it contributes to the literature quantifying impacts of non-discriminatory trade policy changes. Reductions in MFN tariffs are likely the most impactful trade policy change to have been implemented since the middle of the 20th century. But studies have been scarce that quantify of their trade effects while fully accounting for multilateral resistance (Anderson and Van Wincoop, 2003, henceforth AvW). Caliendo et al. (2015) and Heid et al. (2017) are notable exceptions and estimate impacts of MFN tariffs on trade to be large. The former authors find that the Uruguay Round's MFN tariff reductions explain 90 percent of subsequent trade gains, partly as they allowed more firms to become exporters. As the lion's share of global trade is transacted under MFN rates, the result seems intuitive. ${ }^{9}$ In our view, product-level data, as used by Caliendo et al. (2015) and here, has been underutilized by expost studies examining impacts of multilateral trade liberalization. ${ }^{10}$ The gravity literature instead gravitated towards evaluating impacts of discriminatory policies, such as regional and preferential trade agreements (RTAs). ${ }^{11}$ The proliferation of RTAs surely incentivized this focus, but the desire to avoid the AvW critique while continuing to study aggregate bilateral trade data surely also played a role. ${ }^{12}$ Finally, several other studies quantify impacts of

\footnotetext{
${ }^{9}$ Also, preferential rates, where they exist, have been found to be underutilized given a fixed cost in using them, for instance from documentation requirements for rules of origin (Augier et al., 2005; Keck and Lendle, 2012).

${ }^{10}$ In contrast, information on product-level trade and tariffs is routinely employed in ex-ante CGE simulation studies, including for WTO agreements. See Harrison et al. (1997) on the Uruguay Round and Hoekman et al. (2010) on a prospective Doha outcome.

${ }^{11}$ Freund and Ornelas (2010) provide a survey.

${ }^{12} \mathrm{Head}$ and Mayer (2014) note that "In the presence of importer and exporter fixed effects [to control for AvW's multilateral resistance] a variety of potentially interesting [non-discriminatory] trade determinants can no longer be identified in a gravity equation." Studies of discriminatory policies, however, are still possible on aggregate bilateral trade data. For identification, studies of RTAs generally compare imports from RTA partners to those from non-RTA partners.
} 
preference erosion. ${ }^{13}$

Second, this paper contributes to literatures on WTO trade effects and trade policy certainty. Earlier empirical literature on trade impacts of WTO membership did not account explicitly for tariff reductions. This again largely resulted from estimations proceeding on aggregate bilateral trade flows, rather than product-level data. Also, estimations typically only included a WTO membership dummy, thereby conflating into a single coefficient impacts of reducing/eliminating tariffs and impacts due to higher trade policy certainty. This literature initially encountered challenges to find significant WTO effects (Rose, 2004), although later research does so for limited groups of members (Subramanian and Wei, 2007; Eicher and Henn, 2011). While our focus is not on all WTO accessions and therefore less broad, we bring more structure to the trade impacts. We distinguish impacts of reducing and eliminating MFN tariffs from those generated via enhanced trade policy certainty. This integrates insights of a more recent literature, which finds that trade policy certainty underpins imports (Groppo and Piermartini, 2014; Osnago et al., 2015) as well as fosters exports through FDI-driven development of domestic export industries (Antràs and Helpman, 2008; Gawande et al., 2011; Handley and Limão, 2013, 2015; Osnago et al., 2016). ${ }^{14}$

Third, our work adds to large literatures on trade agreements and international production sharing (e.g., Antràs and Staiger, 2012). The sizable magnitudes of many of our estimates support the hypotheses of (i) Yi (2003) that effects of trade policy changes on trade should be especially high in GVC sectors and (ii) Ornelas and Turner (2008) who emphasize that tariff liberalization boosts trade more than would be expected in standard models. Reason is that tariffs aggravate the hold-up problem of underinvestment when contract enforcement is imperfect. In line with Yi's (2003) theoretical argument, Bridgman's (2012) simulation analysis emphasizes that declining trade costs are crucial in understanding the rise of trade in intermediates. Our results illustrate that the ITA indeed facilitated deeper GVC integration in the goods that it covers, relative to closely comparable products.

Finally, this paper advances a small literature on the ITA. WTO (2012) provides a comprehensive analysis of the formation, membership and coverage overview of the ITA, on which we build to identify the passive signatory group. Mann and Liu (2009), with Bora and Liu (2010) further developing their work, provide the only econometric analyses of trade impacts of the ITA. They find that ITA signatories imported on average 14 percent more ITA goods after accession than non-members of the WTO. Instead of our detailed product-level data, these studies use a dummy-variable approach on overall ITA trade and only focus on one aggregate impact on the import side. Their short time coverage implies that many important passive signatories are not covered. ${ }^{15}$

\footnotetext{
${ }^{13}$ Frazer and Van Biesebroeck (2010) and Hakobyan (2013) are examples and evaluate how WTO deals erode preferences previously created through GSP schemes. These studies essentially also study discriminatory policies, only in reverse.

${ }^{14}$ Given lack of FDI data specific to the ITA sector, we maintain our focus on trade flows and therefore test this indirectly.

${ }^{15}$ These studies use data through 2003, while this paper covers the period 1996-2012. Another difference is that these studies estimate log-linearized gravity equations by OLS. They therefore eliminate zero trade flows
} 


\section{The Information Technology Agreement (ITA)}

\subsection{Six unique characteristics and the quasi-natural experiment}

Not only is ITA the prime example of near-global MFN tariff elimination, it also provides a uniquely favorable setting in six respects to study the impact thereof.

First, the ITA liberalized tariffs on a broad set of IT products, but did not cover many others; this provides a natural control group. The original ITA lists 190 covered products in a rigid positive listing. These 190 products correspond to 154 HS1996 subheadings, i.e. 6-digit product codes, but many subheadings are only covered partially, as detailed in WTO (2012). This makes the ITA's product coverage complex, adding challenges to the construction of our dataset (Section 4). The positive listing of the ITA implies that new ICT products generally are not covered. ${ }^{16}$ This provides good preconditions for our use of cross-product variation for identification. Our estimations ask whether trade in ITA goods accelerated more rapidly than that in other information and communication technology (ICT) goods after the agreement came into effect. That the ITA is a stark case further facilitates this cross-product comparison: While tariffs on ITA goods were eliminated, there were no large and coordinated changes of tariffs in our control groups of other ICT goods and machinery goods. ${ }^{17}$

Second, the ITA eliminated tariffs completely, thereby allowing us to study tariff elimination effects. This is another advantage of studying the ITA rather than WTO accessions in general, under which complete tariff elimination is much less widespread. After the ITA's inception in mid-1997, founding members implemented zero tariffs by 2000, but some developing countries had longer implementation periods (up to 2005 at the latest). Implementation periods for countries joining after 1997 have been determined in negotiations and therefore varied, but in most cases did not surpass three years.

Third, the ITA did nothing else but eliminate tariffs - this allows us to isolate how much trade policy certainty related to tariff elimination is worth. ITA members committed to adjust their MFN applied and bound tariffs to zero. Thereby liberalization under the ITA is (i) hard to reverse and (ii) enforceable through the WTO dispute settlement system. Because the ITA did not do anything else but eliminate tariffs, it allows us to cleanly quantify a trade policy certainty effect related exclusively to locking in tariff elimination. In contrast, many other

and heteroskedasticity is a concern - unlike in our PPML estimation of a multiplicative gravity equation. For comparability to this previous literature, we provide in Appendix Table A4 a version of our baseline results derived from a sample without zero trade flows. Appendix Table A5 in addition estimates the first stage on a log-linearized gravity equation using OLS.

${ }^{16}$ Trade coverage of the 190 ITA products therefore eroded over time, motivating the 2016 expansion of the ITA, but the positive list strategy was maintained. Resulting complex product coverage therefore remains a point of criticism and has caused a dispute in the WTO (Dreyer and Hindley, 2008).

${ }^{17}$ Note that a cross-product identification strategy could in principle also work to study WTO accessions through which tariffs are reduced more on some products than others. However, identification would be more challenging, because products with differential tariff reductions may be less comparable and subject to very different shocks. 
(especially preferential) trade agreements also cover other areas, including NTMs, thereby making it very difficult to disentangle how important - by itself - tariff certainty is.

Fourth, endogeneity concerns are allayed through our quasi-natural experiment. The context in which latecomers joined the agreement was generally different from that of founding members. Their accession can be considered largely exogenous as it came as a by-product of the pursuit of a larger policy objective, as opposed to being a result of self selection. Thereby these passive signatories constitute a quasi-natural experiment. There were three motivations behind the accessions of these countries. First, for most countries acceding to the WTO after 1997, joining the ITA was made part of their WTO accession protocol. Second, all recent members of the European Union (EU) had to adopt the trade policy of the EU upon accession or in the preparatory process and hence joined the ITA, unless they had already acceded earlier. Third, the U.S. was one of the initiators of the ITA and has actively persuaded potential RTA partners to join the ITA. In contrast, active signatories actively sought out ITA membership and include all founding members as well as late signatories whose accession was not mainly motivated by one of the three broader policy objectives.

Table 1 presents the lists of active and passive signatories as well as accession years for all non-founding members. Passive signatories entered the agreement in various years. Thirteen economies were classified as passive signatories due to WTO accession and another fifteen because their ITA accession was related to EU accession or negotiations of an RTA with the U.S. The classification is based on the detailed discussion of the ITA negotiation process in WTO (2012), which states in Section II.F that "Besides those WTO members that joined the ITA on their own initiative, this section explains the manner in which procedures to join the WTO, bilateral free-trade agreement negotiations by the United States and two EU enlargements have all contributed in this respect." However, we in addition assessed potential passive signatories individually to reconfirm that they indeed joined the ITA for its own merits or as part of a larger policy objective. Annex I summarizes the extensive evidence.

Fifth, the ITA's critical mass agreement nature implies that trade diversion is hardly a concern. As the ITA is a multilateral "critical mass agreement" under the WTO its founding members represented, upon its inception, more than 90 percent of world trade in products covered by the agreement. The ITA requires members to apply agreed tariff concessions on an MFN basis to all WTO members, whether they are ITA signatories or not. ${ }^{18}$ Negotiations among 34 countries were finalized in 1996. Nine more countries signed up by a March 1997 deadline, which made the agreement surpass the 90 percent "critical mass" threshold. The agreement came into force on July 1, 1997. After ITA inception, countries with growing IT export sectors, such as China, joined the agreement. Membership increased to 74 countries by 2012, the end of our sample period, and 82 by 2017.

\footnotetext{
${ }^{18}$ Therefore, trade diversion among WTO members is hardly a concern in our analysis. While there could be some trade diversion away from (the few) non-WTO members, to whose exports the lower ITA tariffs do not apply de jure, in practice importers also apply their MFN tariffs to WTO nonmembers (Rose, 2004).
} 
Table 1: ITA members categorized by motivation driving their ITA accession

\begin{tabular}{lll}
\hline "Active" ITA signatories, including & all founding members & \\
\hline Australia & Hong Kong, China & New Zealand \\
Austria & Iceland & Norway \\
Belgium & India & Philippines \\
Canada & Indonesia & Poland \\
Chinese Taipei ${ }^{2}$ & Ireland & Portugal \\
Costa Rica & Israel & Romania \\
Czech Republic & Italy & Singapore \\
Denmark & Japan & Slovak Republic \\
Egypt (2003) & Korea, Republic of & Spain \\
El Salvador & Kuwait (2010) & Sweden \\
Estonia & Liechtenstein & Switzerland \\
European Union & Luxembourg & Thailand \\
Finland & Macao, China & Turkey \\
France & Malaysia & United Arab Emirates (2007) \\
Germany & Mauritius (1999) & United Kingdom \\
Greece & Netherlands & United States of America \\
& & \\
\hline
\end{tabular}

"Passive" ITA signatories, whose ITA accession was likely significantly motivated by...

\begin{tabular}{lll}
\hline WTO accession & EU accession & US FTA \\
Albania $(1999)^{3}$ & Bulgaria (2002) & Bahrain, Kingdom of (2003) \\
China (2003) & Cyprus (2000) & Colombia (2012) \\
Croatia $(1999)^{3}$ & Hungary (2004) & Dominican Republic (2006) \\
Georgia (1999) & Malta (2004) & Guatemala (2005) \\
Jordan (1999) & Slovenia (2000) & Honduras (2005) \\
Kyrgyz Republic (1999) & & Morocco (2003) \\
Latvia (1999) & & Nicaragua (2005) \\
Lithuania (1999) & & Panama (1998) \\
Moldova, Republic of (2001) & & \\
Oman (2000) & & \\
Saudi Arabia, Kingdom of (2005) & & \\
Ukraine (2008) & & \\
Viet Nam $(2006)^{3}$ & & \\
\hline
\end{tabular}

Sources: Authors' compilation based on WTO (2012) and information obtained through interviews of various WTO Secretariat staff.

1 ITA founding members joined in 1997. Accession year for all non-founding members is given in parentheses.

2 Among ITA founding members, Chinese Taipei and Estonia were the only ones which only joined the WTO subsequently (in 2002 and 1999 , respectively). They had ITA membership as a requirement in their WTO accession protocols, we classify them as active signatories because they were founding members and acceeded before their WTO accession.

3 These countries already joined the ITA during their WTO accession process in the calendar year before WTO accession (only Lithuania acceeded the WTO two calendar years later, in 2001). 
Sixth, reversal of pre-ITA trade diversion is not a large issue. For country pairs with pre-existing RTAs, ITA eliminated their tariff preferences. Therefore, trade with the new ITA partners may increase more as previous RTA-internal trade is reverted to them, and this could bias coefficients on ITA-related effects. ${ }^{19}$ While our estimation strategy explicitly accounts for this, it is also favorable that the ITA came into being only in 1997 - before RTAs truly proliferated. Similarly, it is favorable that developing countries that were covered by pre-existing GSP schemes did not have a large IT sector (Section 3.2; Appendix Figures A1 and A2).

Our analysis focuses exclusively on the original ITA, although our broad conclusions may also of interest in light of the ITA's 2016 expansion to another 201 products among a more limited set of 53 member countries, of which WTO (2017) provides an overview.

\subsection{A first glance at the ITA's impact}

Tariffs on ITA products were generally already low before accession for member countries. This is particularly true for active signatories, whose ITA product tariffs averaged 2.5 percent in the year before accession. Passive signatories had somewhat higher tariffs in the year before accession, averaging 3.9 percent. ${ }^{20}$ However, they had been reducing their tariffs considerably on these goods already before accession (Figure 1). Although ITA goods had somewhat lower tariffs than other ICT goods before accession, the two types of goods followed very similar trends. After accession, ITA goods tariffs follow a steeper downward trajectory toward zero than those of other ICT goods.

Passive signatories' importance in world ITA goods trade has grown immensely over our sample period. These gains have come at the expense of active signatories, which are predominantly developed countries. Although China stands out, Figure 2 illustrates that other passive signatories have recorded remarkable increases in their world market shares as well, albeit from a low base. Over the sample period, China has become a dominant player in IT products and this raises concerns that a large part of our results could be driven by China. We therefore run all our regressions twice: once on the whole sample and on a sample excluding China's exports.

Both for China and other passive signatories, increases in market shares are more impressive for exports than imports. This illustrates that, geographically speaking, import demand for ITA goods remained relatively stable over time, while the origin of products changed significantly in the last two decades, arguably driven in part by location and sourcing decisions of multinational enterprises as described in the GVC literature.

Figure 3 further explores export trends among these country groups over time. Both exports of active signatories and non-members show only moderate growth. Passive signa-

\footnotetext{
${ }^{19}$ We thank an anonymous referee for highlighting this point.

${ }^{20}$ These average tariff figures include preferential tariffs. Average MFN applied tariffs are somewhat higher, 3.8 and 6.3 percent for initial and late signatories, respectively.
} 
Figure 1: Average applied import tariffs on ITA and other ICT goods by active and passive ITA signatories (percent)

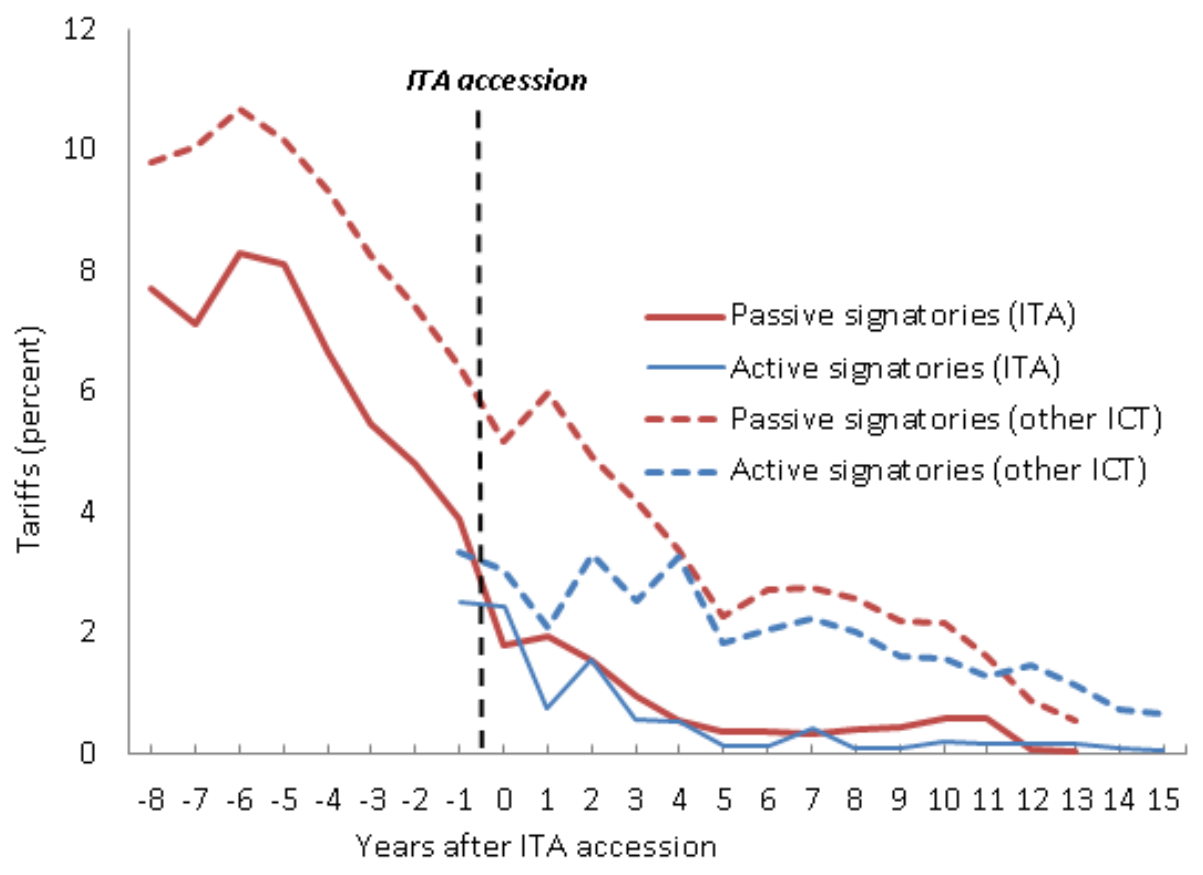


tories instead have a much steeper slope. When the lower initial start value is taken into account, the expansion of their exports almost matches that of China. However, Figure 3 does not provide a good notion of whether ITA accession may have driven growth in passive signatories, because many passive signatories were not yet ITA members at the beginning of the period covered in the figure.

To obtain a notion of whether ITA accession may have boosted exports of passive signatories, we therefore evaluate how their exports have evolved before and after ITA accession. To eliminate influences of global fluctuations in ITA trade, we now look at market shares, which we rescale to 100 in the entry year to allow for simple averaging across countries. To retain a sufficient number of countries in the sample, we focus only on the 7 years before the ITA entry year and 5 years after. Figure 4 presents the results. Twelve passive signatories can be observed during such a 12-year time window ("Constant Country Sample"). To check the robustness of the ITA exports pattern over time across a larger set of passive signatories, we also look at all passive signatories ("Changing Country Sample") during this 12-year period. For both samples, the figure indeed suggests that export market shares of passive signatories start to increase substantially around the time of ITA accession. The figure includes China, but it is insensitive to its exclusion.

Figure 2: World market shares in ITA products by type of accession, 1996 and 2012

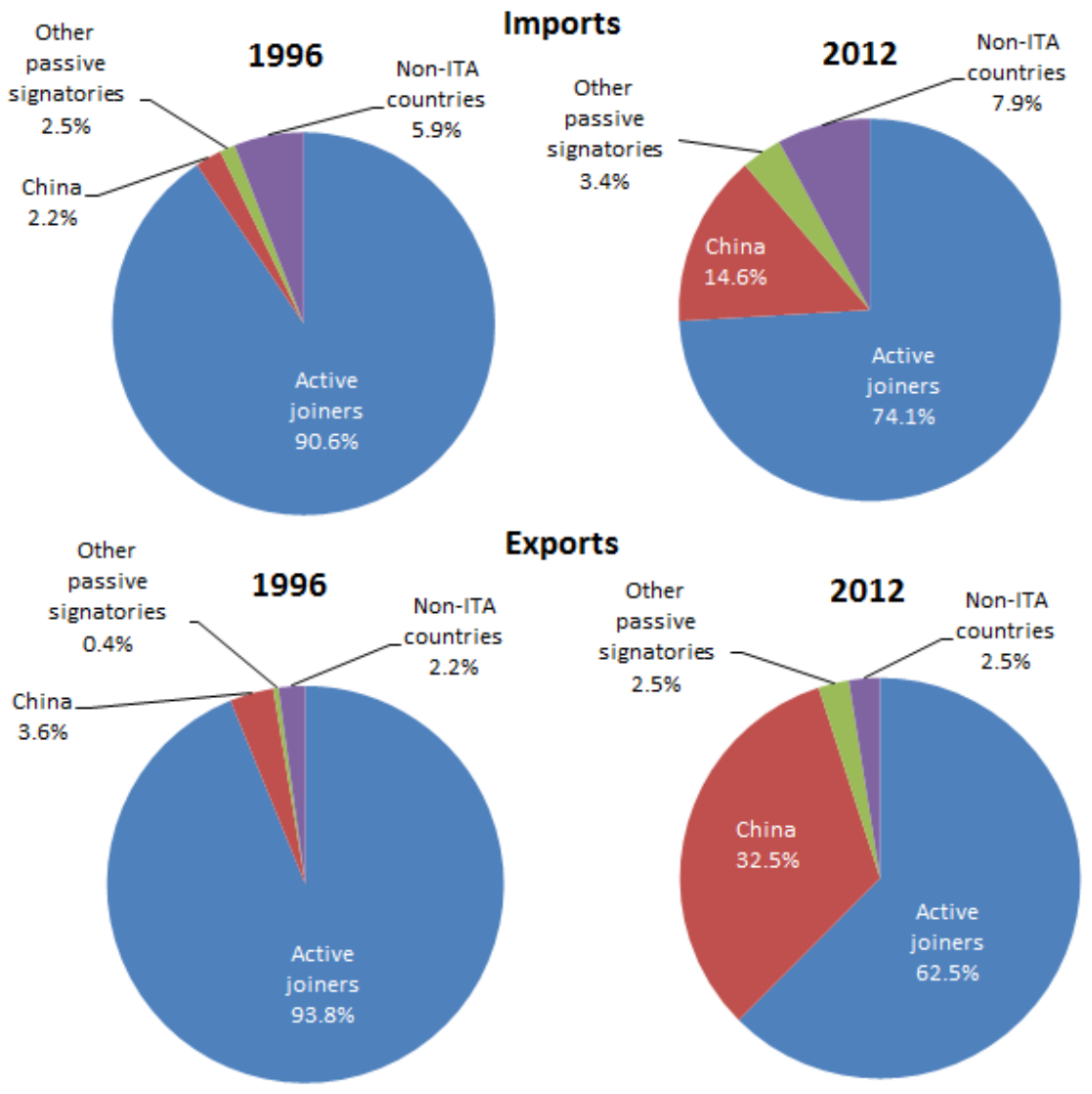


Figure 3: Nominal export value of ITA products

(index, 1996=100)

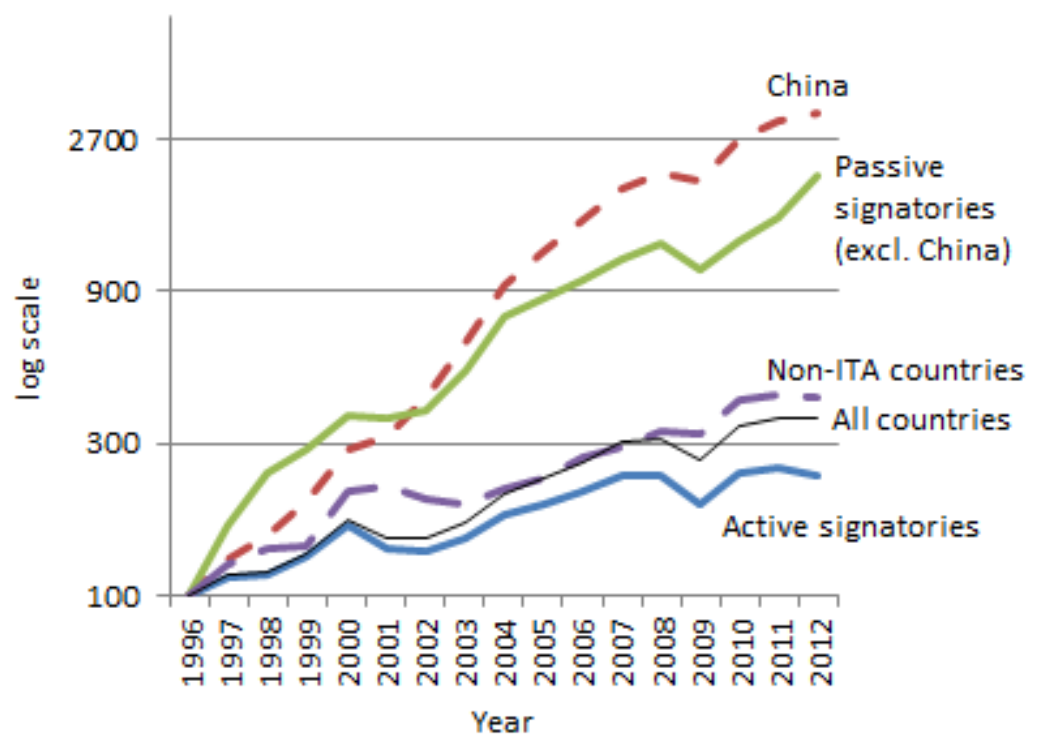

Figure 4: Market share in global ITA product exports of "passive signatories" (index, accession year $=100$ )

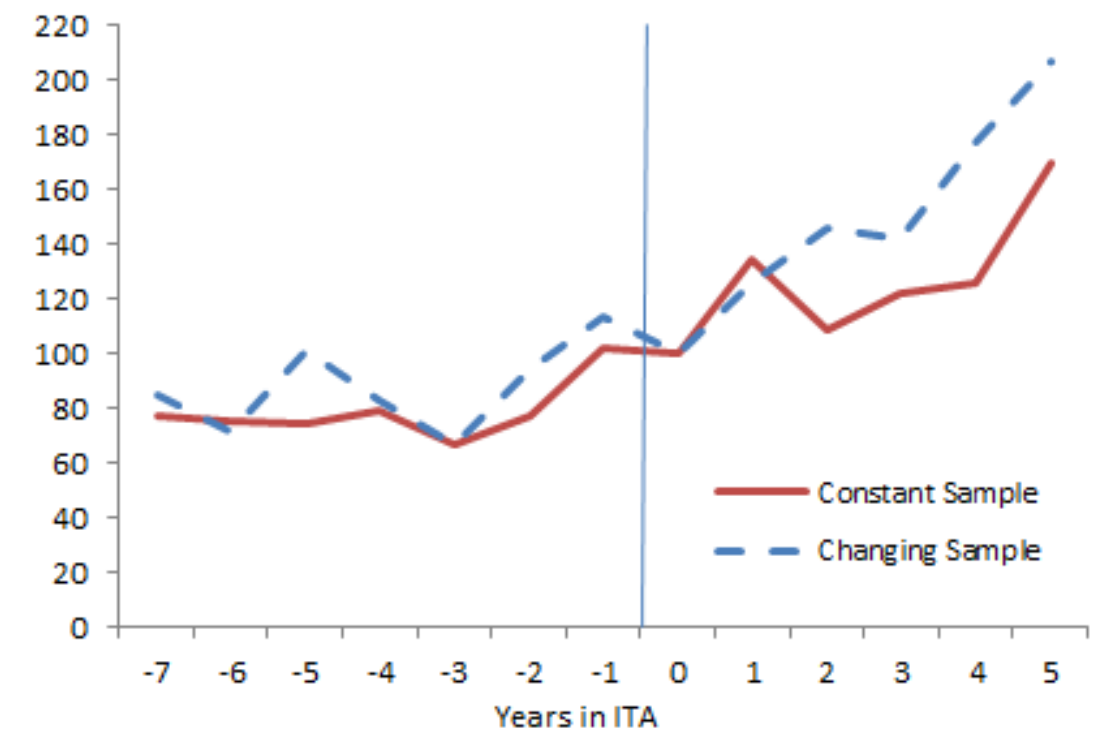


Figure 5: Average ITA product share in total exports by type of ITA accession, 1996-2012 (percent)

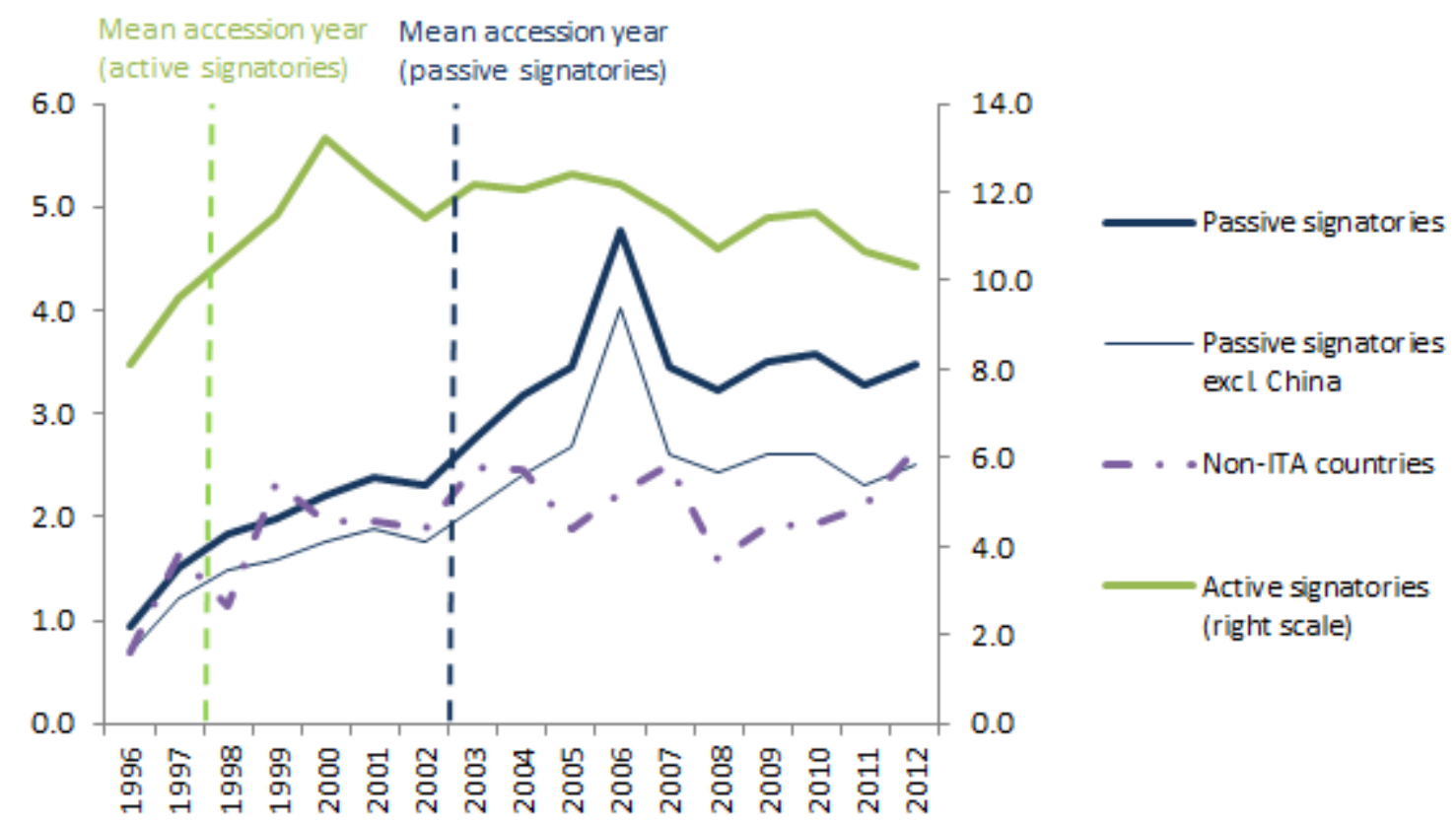

Shares of ITA products in countries' export baskets have also expanded in response to accession (Figure 5). We note that from the mid-1990s until the dot-com bust in 2001, these shares were expanding across all groups. For active signatories, this expansion coincided with the years just after their ITA accession in 1997. But given that IT exports expanded globally, it is hard to attribute this to the ITA. Passive signatories acceded to the ITA in different years, but most did so in 1999 or the early 2000s (Table 1). We calculate a mean accession year for this group of late 2002. Figure 5 suggests that passive signatories experienced growth of their ITA sector after accession. During the mid-2000s, the share of ITA products in their export baskets surged - and stabilized subsequently at a higher level - while those of other countries were stagnant. Thus passive signatories' increasing global ITA export market share of Figure 4 went hand in hand with an increased importance of the sector within their economies.

This suggests that expansion of ITA exports coincided with development of an ITA export sector in passive signatories. Notably, ITA export sectors were small in passive signatories before accession: ITA product exports amounted to only 0.4 percent of passive signatories' GDP on average (median 0.1 percent), while in active signatories they were 2.8 percent of GDP (median 1.0 percent), as depicted in Appendix Figures A1 and A2.

\section{Data}

Our dataset covers 1996-2012 and matches product-level trade data to tariffs, ITA and WTO membership indicators, and common gravity variables. Construction of the dataset 
involves conversions across tariff vintages and translation of the ITA agreement into coverage of tariff lines. ${ }^{21}$

Data on tariffs at the 6-digit level are obtained from UN TRAINS and converted to the HS1996 vintage. WTO and ITA membership data was taken from the WTO website. We collect those gravity variables that vary across time within any country or country-pair from standard sources. ${ }^{22}$

The ITA's list of covered products remained unchanged between its entry into force 1997 and the end of our sample period in 2012. It lists 154 products, which we translate into a coverage of 106 product lines at the 6-digit HS1996 level. ${ }^{23}$ Gross imports data on these product lines is obtained from UN Comtrade. ${ }^{24}$ While use of value-added trade data would be desirable, its granularity is insufficient for identifying an ITA sector and matching detailed tariffs.

To nevertheless add a value chain dimension to our analysis, we classify product lines into those containing mostly intermediate and mostly final goods as in Yeats (2001) and Orefice and Rocha (2014). Sturgeon and Memedovic (2010) provide the needed classification at the HS 6-digit level; it covers 47 of our 106 ITA product lines. ${ }^{25}$ While this leads to a loss of observations in intermediate (final) goods regressions, 680 (825) thousand of a total of 2.5 million ITA observations remain. ${ }^{26}$

Our regressions employ control sectors to assess how ITA trade has performed relative to that of comparable goods. We use two control sectors: other information and communications technology (ICT) goods that are not covered by the ITA, and machinery goods.

For ICT goods, OECD $(2003,2011)$ provide definitions covering 193 product lines at the 6-digit HS1996 classification. Of these 193 lines, 77 overlap with our 106-line ITA definition. Thus non-ITA ICT goods comprise 116 lines. ${ }^{27}$

Finally, we also construct a broad machinery control sector. We select HS sections 84, 85, 87, and 90. These comprise electrical and non-electrical machinery, road vehicles and optical/photographic/precision instruments. They make a good larger comparator group,

\footnotetext{
${ }^{21}$ The Appendix provides further details on these aspects of the construction of our dataset.

${ }^{22}$ Non-time-variant variables such as distance are controlled for by country-pair-product fixed effects in all our specifications.

${ }^{23}$ The 154 products cover 95 of these lines fully and 106 lines almost fully.

${ }^{24}$ Where import data are not available, export data reported by trading partners are filled in.

${ }^{25}$ These authors' classification is congruent, but slightly more detailed, than the correspondence table between BEC Rev. 4 and HS 1996 available at the UN website (which would allow classification of 41 products).

${ }^{26}$ When the ICT (machinery) control sector is added 102 of 202 (165 of 995) 6-digit product lines are covered by the classification.

${ }^{27}$ This implies that 29 ITA lines are not considered ICT goods by the OECD. These 29 lines cover manifold products, mainly printing machinery, electric typewriters and optical photo-copiers; laser discs and magnetic tapes; electric and power capacitators; equipment for measuring liquid or gas; and parts/accessories of aforementioned products.
} 
as they are also highly traded and often integrated in GVCs. This broad machinery sector covers 995 tariff lines, which comprise all those related to ITA and other ICT products. ${ }^{28}$ With its inclusion, our dataset totals 21.8 million usable observations.

\section{Empirical Strategy}

\subsection{Product-level structural gravity}

Our estimation strategy is based on the structural gravity model developed by Anderson and Van Wincoop (2003). We expand their two-dimensional setup (exporter and importer) to include time and product dimensions. Apart from its advantages relating to identification in our application, using product-level data minimizes aggregation bias, because it allows us to account for variations in trade costs and elasticities across products (Clausing, 2001; Anderson and Yotov, 2010a,b).

Our four-dimensional gravity equation is:

$$
x_{i j k t}=\frac{y_{j k t} x_{i k t}}{y_{k t}}\left(\frac{T_{i j k t}}{\prod_{j k t} P_{i k t}}\right)^{1-\sigma}=\frac{x_{i k t}}{P_{i k t}^{1-\sigma}} \cdot \frac{y_{j k t}}{\Pi_{j k t}^{1-\sigma}} \cdot T_{i j k t}^{1-\sigma} \cdot \frac{1}{y_{k t}}
$$

where the $t$ subscript denotes years. The variable $x_{i j k t}$ denotes imports of country $i$ from country $j$ of good $k ; y_{j k t}$ is total production of good $k$ by country $j ; x_{i k t}$ is total expenditure on good $k$ in country $i$; $y_{k t}$ is global production of good $k$; and $T_{i j k t}$ stands for bilateral trade costs. The elasticity of substitution between varieties from different exporters is $1-\sigma$ and would need to be negative, so that we require $\sigma>1$. For simplicity, and given that our analysis is limited to similar IT and machinery products, we constrain $\sigma$ to be the same across all products. ${ }^{29}$ Multilateral resistance, or general equilibrium effects, are represented by $\Pi_{j k t}$, the average outward trade barriers faced by country $j$, and $P_{i k t}$, the average inward trade barriers of country $i$. If a country's multilateral resistance is high, it will be expected to trade more with any bilateral partner at a given bilateral trade cost (than a country with low multilateral resistance). Notably, multilateral resistance varies over time.

In order to quantify the four layers of trade effects generated by ITA's MFN tariff elimination, we employ a two-step estimation strategy. The first-stage PPML estimation proceeds on bilateral product-level data. It quantifies the impact of discriminatory trade policies such as preferential tariffs. But, crucially, it also returns consistent estimates of importer- and exporter-product-time fixed effects. These are then used as dependent variables in two separate second-stage regressions to quantify effects of non-discriminatory trade policies. Both

\footnotetext{
${ }^{28}$ To be exact, two ITA tariff lines (HS 381800: Chemical element/compound wafers doped for electronics; HS 950410: Video games used with the TV receiver) are not covered by the four HS sections, but we retain them in the dataset throughout.

${ }^{29}$ Results containing separate estimates for ITA goods and control sector goods are reported in Table A6 of the Appendix.
} 
second-stage estimations are estimated by OLS. Using the importer-product-time coefficients as the dependent variable, we can estimate three of our layers: the MFN tariff reduction effect, the MFN tariff elimination effect, and the commitment (or trade policy certainty) effect on the importer side. Finally, taking the exporter-product-time coefficients as the dependent variable, we estimate the commitment effect on the exporter side.

To proceed we first specify a functional form for bilateral trade costs. We use the iceberg trade cost specification commonly used in the gravity literature (Yotov et al., 2016), wherein tariffs enter multiplicatively, amplifying the effect of all other trade costs:

$$
T_{i j k t}=\left(1+t_{i j k t}^{\text {Applied }}\right) \cdot \exp \left[\zeta I_{i j t}+\delta_{i j k}\right]=\exp \left[\ln \left(1+t_{i j k t}^{\text {Applied }}\right)+\zeta I_{i j t}+\delta_{i j k}\right]
$$

where $t_{i j k t}^{\text {Applied }}$ is the product-level bilateral applied tariff; i.e. it takes the value of preferential tariffs in country pairs where they exist and the value of the MFN tariff otherwise.

The $I_{i j t}$ matrix includes the few common gravity regressors that vary simultaneously across the importer, exporter, and time dimensions. It comprises dummies for joint currency union membership and for a common preferential or regional trade agreement (RTA). In addition to this overall RTA dummy, another two specific RTA-related variables are included. First, we note that many ITA passive signatories were EU accession countries. With ITA and EU accession often occurring around the same time, it is possible that the ITA commitment effect for passive exporters could erroneously capture EU trade creation if exceeds that of other RTAs. To forestall this possibility, we include a dummy capturing exports to EU partners of countries that joined the EU after 1997. ${ }^{30}$ Second, we add a similar dummy capturing exports to the U.S. of countries that joined an RTA with the U.S. after 1997. Furthermore, the $I_{i j t}$ matrix also contains a "both in WTO" variable to capture any impact of WTO-internal trade creation among its members. ${ }^{31}$

Finally, equation (2) includes a fixed effect term $\delta_{i j k}$ which accounts for all country-pairproduct specific trade determinants that are constant over time - whether observable or unobservable. Given large heterogeneity in bilateral trade relationships, such a fixed effect term has been strongly advocated by various authors and shown to be a better measure of bilateral trade costs than the standard set of gravity variables, including distance, common language, etc. (Baldwin and Taglioni, 2007; Agnosteva et al., 2014; Egger and Nigai, 2015).

\footnotetext{
${ }^{30}$ While some of the EU impact should be picked up by the RTA dummy, some authors have pointed out that trade creation may vary substantially across specific agreements and may be particularly strong for the EU (Eicher et al., 2012).

${ }^{31}$ It captures the idea that WTO members may deviate their trade to each other, given higher the higher trade policy certainty afforded through the WTO.
} 


\subsection{First-stage estimation equation}

Plugging equation (2) into (1), we obtain our first-stage estimation equation. We estimate the first-stage gravity equation in multiplicative form by Poisson Pseudo Maximum Likelihood (PPML), as first proposed by Silva and Tenreyro (2006). As these authors highlighted, PPML estimation allows to avoid heteroskedasticity bias common in OLS estimation of log-linearized gravity equations. PPML also allows us to retain instances of zero trade flows between country pairs: ${ }^{32}$

$$
x_{i j k t}=\exp \left[\alpha_{i k t}+\alpha_{j k t}+\alpha_{i j k}+(1-\sigma) \ln \left(1+t_{i j k t}^{\text {Applied }}\right)+\psi I_{i j t}\right] \cdot \epsilon_{i j k t}
$$

wherein importer-product-time fixed effects $\alpha_{i k t}$ absorb the $x_{i k t} / P_{i k t}^{1-\sigma}$ term, exporterproduct-time fixed effects $\alpha_{j k t}$ absorb the $y_{j k t} / \Pi_{i k t}^{1-\sigma}$ term, ${ }^{33}$ and country pair-product fixed effects $\alpha_{i j k}$ absorb $(1-\sigma) \delta_{i j k} \cdot{ }^{34}$ Also $\psi=(1-\sigma) \zeta$ and $\epsilon_{i j k t}$ is the error term.

Note that the applied tariff term $t_{i j k t}$ will only pick up the impact of preferential tariff margins (over MFN tariffs) in this equation. This is because the MFN tariff - which is constant across all exporters within any importer-product-time combination - will be absorbed by $\alpha_{i k t}$. As a result, the first-stage equation also controls for reversals of trade diversion that occurred as a result of ITA implementation: Consider a country that was profiting from a tariff preference under an RTA or a GSP scheme, which was eliminated through ITA. For this country, the first stage will correctly include a tariff preference in pre-ITA years and a zero tariff preference in post-ITA years. ${ }^{35}$

\subsection{Second-stage importer equation}

Our second-stage regressions provide more structure to AvW's multilateral resistance terms by breaking them down into MFN tariff-related barriers and other multilateral trade costs. We decompose inward multilateral resistance as follows:

$$
P_{i k t}=\exp \left[\gamma_{1} \ln \left(1+t_{i k t}^{M F N}\right)+\gamma_{2} t 0_{i k t}^{M F N}+\gamma_{3} i m i t a_{i k t}\right] \cdot p_{i k t}
$$

\footnotetext{
${ }^{32}$ Elimination of zero trade flows in log-linearized gravity equations has been shown to induce selection bias (Helpman et al., 2008; Head and Mayer, 2014).

${ }^{33}$ The importer- and exporter-product-time effects also absorb $1 / y_{k t}$. In the second stage regressions below, it is then picked up by product-time fixed effects $\delta_{k t}$.

${ }^{34}$ Estimation is computationally challenging given three sets of high dimensional fixed effects in each estimation. We rely on the Stata command $p p m l_{-}$panel_sg for our first-stage PPML estimations and command reghdfe for both second-stage OLS estimations (discussed below). We cluster standard errors by countrypair-product combinations in stage 1 and by importer- and exporter-product-time fixed effects, respectively, in the importer and exporter regressions in stage 2. We thank an anonymous referee for suggesting the two-stage estimation approach.

${ }^{35}$ To reinsure that preference erosion indeed does not get picked up by our coefficients of interest, we repeat our analysis starting from a restricted sample in stage 1 that excludes country pairs with an RTA in place by 1996 . Results are virtually unchanged and reported in Appendix Table A8.
} 
The equation explains a part of inward multilateral resistance $P_{i k t}$ through three effects of non-discriminatory trade policy: the tariff elimination effect associated with $\ln \left(1+t_{i k t}^{M F N}\right)$, and the tariff elimination and importer ITA commitment effects associated with the dummy variables $t 0_{i k t}^{M F N}$ and $i m i t a_{i k t}$, respectively. We elaborate on these further below. The unexplained remainder of inward multilateral resistance is $p_{i k t}$.

Noting that in the first stage $\alpha_{i k t}$ had absorbed $\ln \left(x_{i k t}\right)-(1-\sigma) \ln \left(P_{i k t}\right)$, we can then use the first-stage estimates of $\alpha_{i k t}$ as the dependent variable in our second-stage OLS estimation equation for importers: ${ }^{36}$

$$
\alpha_{i k t}=\delta_{i t}+\delta_{i k}+\delta_{k t}+\beta_{1} \ln \left(1+t_{i k t}^{M F N}\right)+\beta_{2} t 0_{i k t}^{M F N}+\beta_{3} i m i t a_{i k t}+\xi_{i k t}
$$

where $\beta_{l}=(1-\sigma) \gamma_{l}$ for $l=1,2,3$. Importer-time $\delta_{i t}$, importer-product $\delta_{i k}$, and producttime fixed effects $\delta_{k t}$ are used to proxy for the unobservable remainder of inward multilateral resistance $p_{i k t}$ and the unobservable total product-level expenditure in any country, $x_{i k t}$.

The $\delta_{i t}$ effects control for country-time specific heterogeneity, such as national business cycles; ${ }^{37} \delta_{k t}$ proxies for global product-specific shifts over time, such as changes in global demand, product life cycles, or differential productivity changes across products; and $\delta_{i k}$ controls for the time-constant part of country-product specific heterogeneity, such as expenditure patterns, which may also be affected by pre-existing local industry structure to the extent that it drives IT imports. Any variation of $p_{i k t}$ and $x_{i k t}$ that is not absorbed by the fixed effects goes into the error term $\xi_{i k t}$.

It is worthwhile to emphasize that our identification strategy relies on cross-product variation. To determine the importer commitment effect of ITA denoted by $\beta_{3}$, it asks: How have ITA imports performed compared to those of ICT products in any given year after importers joined the ITA (after global product cycles and national business cycles are controlled for)? Similarly, for the other two effects $\beta_{1}$ and $\beta_{2}$, it asks: How have imports performed that were subject to tariff reductions (or elimination) relative to those that were not?

We now briefly discuss the three effects of non-discriminatory trade policy quantified by the second-stage importer equation.

The first is the MFN tariff reduction effect $\beta_{1}$. It provides a straightforward import demand elasticity in response to MFN tariff changes, given that preferential tariff reduction and RTA commitment effects have been cleansed in the first stage when we obtained our dependent variable $\alpha_{i k t}$.

The second is the tariff elimination effect and quite novel. It posits that there are ad-

\footnotetext{
${ }^{36}$ Note that $\alpha_{i k t}$ is the natural $\log$ of the first-stage fixed effect coefficients.

${ }^{37}$ Countries acceeding to the WTO during the last couple of decades were generally required to undertake more onerous reforms (Tang and Wei, 2009). These importer-time effects would also largely capture that effect, given that such reforms were generally broad in scope.
} 
ditional gains above and beyond tariff reduction that arise if MFN tariffs are eliminated completely. To identify those, we include a dummy variable $t 0_{i k t}^{M F N}$ which takes the value of 1 if the MFN tariff is zero. The intuition is akin to that of Rose et al.'s (2000) currency union dummy, which picked up any trade benefits of a currency union going above and beyond reduced FX volatility. Rose's intuition was that a single currency would also reduce other transaction cost, besides reducing FX risk, and thereby create more trade. Our reading of the border administration literature suggests that the same is the case for zero MFN tariffs.

The intuition for our tariff elimination effect is that customs practices result in lower customs clearance costs for, and thereby increased trade of, products subject to zero MFN tariffs. This is because such products are subject to reduced inspection frequency and scrutiny. To see this, note that modern customs administration is risk based, using computer systems to classify the risk of each import declaration, including based on characteristics of the shipment (and those of importer and exporter and their past track record) (De Wulf, 2005). Declarations identified as low risk enjoy faster clearance with no or only simple additional checks in most cases (Hintsa et al., 2011). In case the system advises officials to perform an inspection, it also recommends whether only documents should be checked, but not the load (yellow category); or both documents and the load (red category). Especially the latter can result in more lenghty customs clearance times, which have been shown to substantially decrease trade by the "time in trade" literature (e.g., Djankov et al., 2010; Freund and Pierola, 2015). Risk-based computerized customs systems have not only been adopted in high-income countries but also in most developing countries. ${ }^{38}$

In making their determination which shipments to select for inspection, risk-based systems take into account that traders could misdeclare along three dimensions: (i) by under-valuing the shipment, (ii) by declaring an HS category that is subject to a lower tariff, and (iii) by misrepresenting the country of origin to utilize preferential tariffs, where they exist. Zero MFN tariffs eliminate incentives for cheating under both (i) and (iii), leading to lower inspection probability and rigor, as Moffatt (2016) emphasizes. ${ }^{39}$ Moffatt consequently calls for tariff elimination except of tariffs of strategic value, because it would dramatically reduce the firms' regulatory burden. Point (ii) is the main reason why some administrative burden needs to be maintained even for tariff-free products as it is necessary to curb traders' incentives to misdeclare nonexempt shipments as duty free (Wiese et al., 2014). However, tariff elimination across many similar products, as instituted under the ITA, nonetheless eases customs red tape partially with regards to point (ii). Zero tariffs across broad product categories often lighten the need for traders to prove which HS code best fits the shipment, because in many cases all relevant codes would have zero tariffs. ${ }^{40}$ Finally, zero tariffs reduce the gravity of consequences (e.g., amount of fines), when traders accidentally misrepresent a

\footnotetext{
${ }^{38}$ The Automated System for Customs Data (ASYCUDA), designed by UNCTAD, has been adopted by over 90 primarily developing countries (ASYCUDA, 2017).

${ }^{39}$ In the case that a shipment had been eligible for RTA or GSP preferences, moving to a zero MFN tariff eliminates traders' compliance costs with restrictive rules of origin. Compliance costs, which can be as high as 5 percent of the final good value, often drive low RTA preference utilization rates (Tapp, 2007).

${ }^{40}$ These gains would be present also in case of non-zero tariffs that are constant within a broad product category.
} 
shipment.

The last one of our three effects of non-discriminatory trade policy in this second-stage equation is picked up by the importer ITA membership dummy imita ${ }_{i k t} .{ }^{41}$ When an importer undertakes tariff elimination under the ITA, it is harder to reverse than if undertaken unilaterally. Associated reduction of WTO bound tariffs to zero gives trade partners recourse to the WTO dispute settlement mechanism if tariffs were to be instituted again. This higher trade policy certainty can incentivize investment into starting or expanding a trade relationship with this importer. ${ }^{42}$ In our estimations, we split this importer ITA membership dummy into one for active and one for passive signatories (as defined in Section 2). This allows us to capture differential effects among these two heterogeneous groups.

\subsection{Second-stage exporter equation}

The derivation of our second-stage exporter equation closely follows the importer analogue. We first decompose outward multilateral resistance as follows:

$$
\Pi_{j k t}=\exp \left(\gamma_{4} \operatorname{exita}_{j k t}\right) \cdot \pi_{j k t}
$$

The equation explains a part of outward multilateral resistance $\Pi_{j k t}$ through our fourth and final effect of non-discriminatory trade policy exita ${ }_{j k t}$, which is a dummy equaling one when the exporter is an ITA member. The intuition for exita $a_{k t}$ is that location and sourcing decisions of firms, and thereby also FDI flows and related technology transfer, increasingly depend on import availability in light of global production sharing. Anecdotal evidence suggests for instance that, in short-listing potential production locations, multinational enterprises may only consider such locations that are part of certain international agreements or feature institutions ensuring low risk of disruption of business operations, including importing and exporting. Finally, the unexplained remainder of outward multilateral resistance is $\pi_{j k t}$.

Noting that in the first stage $\alpha_{j k t}$ had absorbed $\ln \left(y_{j k t}\right)-(1-\sigma) \ln \left(\Pi_{j k t}\right)$, we use the exporter-product-time fixed effect estimates as the dependent variable in our second-stage OLS estimation equation for exporters: ${ }^{43}$

$$
\alpha_{j k t}=\delta_{j t}+\delta_{j k}+\delta_{k t}+y_{j k t}+\beta_{4} e x i t a_{j k t}+\eta_{j k t}
$$

where $\beta_{4}=(1-\sigma) \gamma_{4}$. As in the importer analogue (equation 5), this equation contains three sets of fixed effects in $\delta_{j t}, \delta_{j k}$, and $\delta_{k t}$ to proxy for the unobservable remainder of outward

\footnotetext{
${ }^{41}$ Formally, ITA concessions are only guaranteed to WTO members, but in practice it is very common for WTO members to also apply MFN tariffs to non-WTO exporters (Rose, 2004). Therefore our importer commitment effect dummy does not feature variation across exporters, i.e. only varies in the $i k t$ dimensions, and partly explains inward multilateral resistance.

${ }^{42} \mathrm{~A}$ growing literature suggests that trade policy certainty can boost trade, including through investment and entry/location decisions of firms (Handley and Limão, 2013, 2015).

${ }^{43}$ Note that $\alpha_{j k t}$ is the natural $\log$ of the first-stage fixed effect coefficients.
} 
multilateral resistance $\pi_{i k t}$ and the unobservable total production of product $k$ in country $j$, $y_{j k t}{ }^{44}$ The $\delta_{j k}$ effects absorb country-product specific determinants such pre-existing strength of a certain industry, e.g., due to country-specific industrial structure, resources, regulations, or knowledge/human capital. The interpretation of $\delta_{j t}$ and $\delta_{k t}$ is analog to their counterparts importer equation. Any variation of $\pi_{i k t}$ and $y_{j k t}$ that is not absorbed by the fixed effects goes into the error term $\eta_{j k t}$.

\subsection{Concerns: Omitted variables and endogeneity}

Concerns regarding omitted variable bias are alleviated considerably by the extensiveness of our fixed effect controls in both stages. Nonetheless, in the first-stage regression, omitted variable bias could result if there are omitted country-pair-specific determinants that vary over time and are correlated with our regressors. Given the several pair-specific controls already included, we judge this risk to be low. Estimates of the importer- and exporterproduct-time effects, which are our primary interest in stage 1, would likely be least affected. ${ }^{45}$

A possibly larger concern could be omitted variable bias in the second-stage regressions. For such bias to arise in the importer regression for instance, there would need to be variables with $i k t$ specific variation that are correlated with our three layers of effects. If other traderelated policies were adopted around the same time as the changes implemented under the ITA, then our estimates of the latter could be biased. A case in point are non-tariff measures (NTMs), whose adoption may increase after tariff reductions (Kuenzel, 2018). ${ }^{46}$ To generate serious concern for our ITA commitment effect estimates, NTMs would need to be targeted at ITA goods exclusively while omitting similar ICT goods. While such a narrow targeting for NTMs seems unlikely, we also take comfort in the fact that, if NTMs were indeed targeted that narrowly, our coefficients would be biased toward zero. Yet, most our effects turn out to be statistically significant, suggesting that our effects proper tend to outweigh any such NTM effect.

Endogeneity is another potential source of bias and important to consider. There is ample empirical evidence that sectors characterized by higher levels of import penetration receive greater protection (e.g. Trefler, 1993; Lee and Swagel, 1997), which is in line with the predictions of political economy models of trade protection. ${ }^{47}$ It is likely that high import penetration would cause import flows to also be high. We thus need to suspect that high imports would cause higher tariff levels or reduce the likelihood of zero tariffs as well as

\footnotetext{
${ }^{44}$ The latter is unobservable, because we do not have data on domestic consumption at our detailed HS product level.

${ }^{45}$ Because they are determined by all observations for one importer (or exporter) and product in a given year, the influence of an omitted pair-specific determinant would likely be low.

${ }^{46}$ We thank an anonymous referee for pointing this out.

${ }^{47}$ While the seminal model of Grossman and Helpman (1994) predicts that higher import penetration would actually lead to lower levels of protection, Maggi and Rodriguez-Clare (2000) show that this prediction is reversed when the assumptions are relaxed that (i) trade taxes are the government's only policy instrument and that (ii) government has access to non-distortionary taxation.
} 
that of joining the ITA. These import patterns would also likely affect negotiators' decisions regarding which products to include in the ITA agreement.

In absence of appropriate instrumental variables, the standard in the literature - which we follow - has become to rely on detailed sets of fixed effects (Baier and Bergstrand, 2007). Baier and Bergstrand (2004) show that those countries tend to select into trade agreements, which are e.g. more proximate to each other and have similar income levels, but these characteristics also determine trade flows. The importer-exporter-product fixed effects in our analysis can account for most of these largely time-invariant bilateral characteristics, which were likely instrumental in determining countries' selection into the set of ITA founding members, late joiners, and non-participants. The importer- and exporter-product-time fixed effects help control for endogenous selection of products into the agreement during ITA negotiations. These fixed effects' time variation also controls for any changes over time, e.g., in import penetration, that may have swayed countries' decisions to join or decisions which products to include in the ITA. While we are confident that these fixed effects control for endogeneity quite comprehensively, it is worthwhile emphasizing that, again in this case, any remaining endogeneity would bias our estimates toward zero. Thus, to the extent that some endogeneity remained, our estimates would need to be interpreted as lower bounds.

Finally, we can limit the estimation sample to only passive signatories and exploit the quasi-natural experiment. Passive signatories' accessions to the ITA came about largely exogenously in the pursuit of a larger policy objective, as discussed above, and they could not influence the list of products covered by the ITA. We therefore compare results from this specification largely devoid of endogeneity concerns to those obtained from the full sample. This comparison suggests that our estimation strategy addresses endogeneity well also in the full sample.

\section{Results}

This section presents the results obtained from the full sample, which we take as our baseline (Table 2). The results from a sample including only passive signatories and nonmembers - presented in Section 7.2 below - closely mirror the baseline. We opt to present the full sample results as our baseline, because they allow for a more comprehensive discussion, including of ITA's impacts on active signatories. 
Table 2: The layers of ITA trade effects

\begin{tabular}{|c|c|c|c|c|c|c|}
\hline \multirow{2}{*}{$\begin{array}{l}\text { Type of goods } \\
\text { Sample } \\
\text { Regression Set }\end{array}$} & \multicolumn{2}{|c|}{ All goods } & \multicolumn{2}{|c|}{ Intermediate } & \multicolumn{2}{|c|}{ Final } \\
\hline & $\begin{array}{l}\mathrm{ICT} \\
(1)\end{array}$ & $\begin{array}{l}\text { Machinery } \\
\quad(2)\end{array}$ & $\begin{array}{c}\mathrm{ICT} \\
(3)\end{array}$ & $\begin{array}{l}\text { Machinery } \\
\text { (4) }\end{array}$ & $\begin{array}{l}\mathrm{ICT} \\
(5)\end{array}$ & $\begin{array}{l}\text { Machinery } \\
\quad(6)\end{array}$ \\
\hline \multicolumn{7}{|c|}{ Stage 1 (PPML). ${ }^{1}$ Dependent variable: bilateral product-level imports } \\
\hline $\begin{array}{l}\text { Preferential tariff reduction } \\
\ln (1+\text { tariff })\end{array}$ & $\begin{array}{c}-1.150^{* * *} \\
(-3.66)\end{array}$ & $\begin{array}{l}-0.472^{*} \\
(-2.03)\end{array}$ & $\begin{array}{l}-1.608^{*} \\
(-2.37)\end{array}$ & $\begin{array}{r}-0.582^{+} \\
(-1.66)\end{array}$ & $\begin{array}{l}-0.601 \\
(-1.57)\end{array}$ & $\begin{array}{l}-0.533 \\
(-1.15)\end{array}$ \\
\hline $\begin{array}{l}\text { Observations } \\
R^{2}\end{array}$ & $\begin{array}{c}8,120,335 \\
0.9837\end{array}$ & $\begin{array}{c}32,162,466 \\
0.9867\end{array}$ & $\begin{array}{c}1,583,430 \\
0.9730\end{array}$ & $\begin{array}{c}3,329,109 \\
0.9784\end{array}$ & $\begin{array}{c}2,466,917 \\
0.9926\end{array}$ & $\begin{array}{c}3,069,076 \\
0.9914\end{array}$ \\
\hline \multicolumn{7}{|c|}{ Stage 2 for importers $(\mathrm{OLS}) .^{2}$ Dependent variable: importer-product-time FEs } \\
\hline MFN tariff reduction & $\begin{array}{l}-0.265 \\
(-1.47)\end{array}$ & $\begin{array}{c}-0.687^{* * *} \\
(-8.81)\end{array}$ & $\begin{array}{l}-0.652 \\
(-1.22)\end{array}$ & $\begin{array}{c}-0.847^{* *} \\
(-3.17)\end{array}$ & $\begin{array}{l}-0.548^{+} \\
(-1.72)\end{array}$ & $\begin{array}{l}-0.090 \\
(-0.45)\end{array}$ \\
\hline Tariff elimination effect & $\begin{array}{c}0.063^{* * *} \\
(4.04)\end{array}$ & $\begin{array}{l}0.121^{* * *} \\
(14.75)\end{array}$ & $\begin{array}{c}0.169^{* * *} \\
(4.20)\end{array}$ & $\begin{array}{c}0.131^{* * *} \\
(4.15)\end{array}$ & $\begin{array}{l}-0.029 \\
(-1.14)\end{array}$ & $\begin{array}{c}0.046^{+} \\
(1.86)\end{array}$ \\
\hline $\begin{array}{l}\text { Commitment effect: } \\
\text { active ITA importers }\end{array}$ & $\begin{array}{l}-0.024 \\
(-0.50)\end{array}$ & $\begin{array}{l}0.019 \\
(0.50)\end{array}$ & $\begin{array}{l}0.038 \\
(0.33)\end{array}$ & $\begin{array}{l}0.116 \\
(1.36)\end{array}$ & $\begin{array}{l}0.183^{*} \\
(2.10)\end{array}$ & $\begin{array}{l}0.090 \\
(1.08)\end{array}$ \\
\hline $\begin{array}{l}\text { Commitment effect: } \\
\text { passive ITA importers }\end{array}$ & $\begin{array}{c}0.131^{* * *} \\
(3.38)\end{array}$ & $\begin{array}{c}0.0689^{*} \\
(2.23)\end{array}$ & $\begin{array}{c}0.470^{* * *} \\
(4.77)\end{array}$ & $\begin{array}{c}0.235^{* *} \\
(3.24)\end{array}$ & $\begin{array}{l}0.065 \\
(1.02)\end{array}$ & $\begin{array}{l}0.094 \\
(1.54)\end{array}$ \\
\hline Observations & 367,521 & $1,729,821$ & 75,069 & 151,923 & 105,377 & 148,161 \\
\hline Adjusted $R^{2}$ & 0.8333 & 0.8333 & 0.8266 & 0.8507 & 0.8548 & 0.8306 \\
\hline \multicolumn{7}{|c|}{ Stage 2 for exporters (OLS). ${ }^{3}$ Dependent variable: exporter-product-time FEs } \\
\hline $\begin{array}{l}\text { Commitment effect: } \\
\text { active ITA exporters }\end{array}$ & $\begin{array}{l}0.003 \\
(0.05)\end{array}$ & $\begin{array}{l}-0.049 \\
(-0.98)\end{array}$ & $\begin{array}{l}-0.006 \\
(-0.03)\end{array}$ & $\begin{array}{l}0.087 \\
(0.60)\end{array}$ & $\begin{array}{l}-0.157 \\
(-1.45)\end{array}$ & $\begin{array}{l}-0.032 \\
(-0.33)\end{array}$ \\
\hline $\begin{array}{l}\text { Commitment effect: } \\
\text { passive ITA exporters }\end{array}$ & $\begin{array}{c}0.157^{* *} \\
(2.70)\end{array}$ & $\begin{array}{c}0.210^{* * *} \\
(4.95)\end{array}$ & $\begin{array}{l}0.203 \\
(1.39)\end{array}$ & $\begin{array}{r}0.188^{+} \\
(1.90)\end{array}$ & $\begin{array}{l}0.230^{*} \\
(2.19)\end{array}$ & $\begin{array}{c}0.334^{* * *} \\
(3.55)\end{array}$ \\
\hline $\begin{array}{l}\text { Commitment effect } \\
\text { other than China }{ }^{4}\end{array}$ & $\begin{array}{l}0.126^{*} \\
(2.06)\end{array}$ & $\begin{array}{c}0.216^{* * *} \\
(4.82)\end{array}$ & $\begin{array}{l}0.173 \\
(1.13)\end{array}$ & $\begin{array}{r}0.202^{+} \\
(1.94)\end{array}$ & $\begin{array}{c}0.198^{+} \\
(1.80)\end{array}$ & $\begin{array}{c}0.303^{* *} \\
(3.15)\end{array}$ \\
\hline Obser & 335,896 & $1,389,361$ & 63,661 & 133,096 & 97,005 & 130,472 \\
\hline Adjusted $R^{2}$ & 0.7336 & 0.7012 & 0.7508 & 0.7405 & 0.7237 & 0.7234 \\
\hline
\end{tabular}

Notes: $+{ }^{*},{ }^{* *}, * * *$ denote 10, 5, 1, 0.1 per cent significance levels, based on robust standard errors clustered by country-pairproduct combinations in the first-stage regressions and by importer-product or exporterr-product combinations, respectively, in the second-stage regressions.

${ }^{1}$ Regression includes importer-exporter-product, import-product-time and exporter-product-time fixed effects.

Additionally, all first-stage regressions include a "Both in WTO" dummy, separate dummies for exports of late joiners of the EU and US FTAs covered under these agreements, and regional trade agreement and common currency dummies. Given the extensive fixed effect controls, the coefficients of these controls are insignificant; these results are in Appendix Table A1.

2 Regression includes importer-time, importer-product and product-time fixed effects.

${ }^{3}$ Regression includes exporter-time, exporter-product and product-time fixed effects.

4 These coefficients are obtained from an exact analog regression that excludes China's exports from the sample. The commitment effect for passive ITA exporters is the only one to substantially vary as a result of such a sample modification. The full regression results from this restricted sample are in Appendix Table A7. 
The rows of Table 2 distinguish between the different layers of impact, alongside which we will structure our discussion. For the export commitment effect, we also report estimates from analogue regressions excluding China's exports from the sample (gray shading). While impacts at the other layers are insensitive to China, export commitment effects experience some limited variation in response to China's exclusion. ${ }^{48}$ Table 2's columns cover two dimensions. First, they compare the effects in the "all goods sample" with those in intermediate and final goods. As not all product lines can be classified into intermediate and final goods, sample selection effects imply that the "all goods" estimates do not necessarily lie between the former two. Second, it presents estimates based on two product group samples: a narrower one covering only ITA and other ICT goods (Regressions 1, 3, 5), and a broader one covering the entire machinery sector (Regressions 2, 4, 6), which in addition also covers other non-IT machinery.

Our preferred specification varies depending on the effect we would like to judge. For the tariff reduction and elimination effects, our preferred estimates are based on the machinery sample. The reason is that for those effects, we compare for identification these products subject to tariff reduction/elimination to those not subject to tariff reduction/elimination, and a larger estimation sample is helpful to achieve precise estimation. In contrast, the case is less clear cut for the ITA commitment effects. With these effects, we directly contrast ITA goods to control sector goods. Therefore, ICT goods would seem the preferable control group, just because they are more similar to ITA goods. On the other hand, their trade may also increase as ITA goods are traded more, if there are strong complementarities and both types of goods are intermediate components of larger final goods. This would suppress the magnitude of the ITA effects. ${ }^{49}$ Given these opposing arguments, we refer to the coefficients of both the ICT and machinery samples when discussing the ITA commitment effects.

\subsection{Preferential and MFN tariff reduction effects}

Our stage 1 coefficient on the applied tariff variable quantifies how much exporters increase trade with an importer after the importer starts granting them RTA or GSP tariff preferences. ${ }^{50}$ The coefficient quantifies the implied tariff elasticity $1-\sigma$. Obtained estimates imply that the requirement of $\sigma>1$ is fulfilled and suggest that a one percent reduction of tariffs on ITA products would cause a 0.5 to 1.6 percent increase in imports. The effects are stronger for intermediate than for final goods. This is intuitive in light of global value chains, as firms would cluster more production steps in one country if tariffs

\footnotetext{
${ }^{48}$ Full results from regressions on a sample excluding China's exports are available in Appendix Table A7. We also explored whether results change further when Chinese imports are excluded; this is not the case.

${ }^{49}$ If attenuation bias in case of such production complementarity were particularly strong for intermediate goods, and we would expect see larger coefficients for final goods. However, our results are particularly strong for intermediate goods; therefore, we judge that production complementarity effect would seem to be rather small.

${ }^{50}$ Note that, in the first stage, the MFN tariff is absorbed into the importer-product-time fixed effect, leaving the tariff variable to absorb only preferential effects.
} 
are higher, thereby reducing intermediate goods flows (Yi, 2003). ${ }^{51}$ Finally, the coefficient estimates vary somewhat between the ICT and machinery samples, with those derived from the preferred latter sample being lower in absolute value.

That our estimates are lower than those reported in many other studies is likely due to high concentration in the IT sector. For instance Head and Mayer (2014) in their meta study find average elasticity estimates of $-5 .{ }^{52}$ However, they also emphasize that sectoral estimates vary widely. Bas et al. (2017) report small and statistically insignificant elasticity estimates for the electrical machinery sector, which contains most ITA products and suggests high concentration in the sector. For cases of high concentration, Head and Mayer (2014, Section 5.3.2) caution that estimated elasticities of substitution can be noisy proxies of price elasticities. ${ }^{53}$ High concentration in the IT sector is also confirmed by anecdotal evidence: Both the United States and the European Commission fined a series of firms producing dynamic random access memory semiconductors (DRAMs) for cartel formation during 1999 to 2002 (Connor, 2014).

Moving on to the second-stage regression for importers, we find that MFN tariff reductions likely drive additional trade increases. Our preferred estimate suggests that imports increase by 0.7 percent in response to a 1 percentage point reduction of MFN tariffs. Again, the impact is larger on the intermediate goods sample, in line with the intuition that low trade costs are particularly important within GVCs, because goods are often shipped several times across borders, either as small components or part of larger intermediates. Estimates obtained from the ICT goods sample are less precisely estimated and smaller in magnitude.

\subsection{Tariff elimination effect}

Our estimates highlight a quite novel and large non-linear trade effect of tariff reductions. To our knowledge, zero tariff dummies to capture tariff elimination effects have not been included in the gravity literature. In fact, much of the literature does not even include tariffs as an explanatory variable, partly for data availability reasons. Our estimates of the tariff elimination effect suggest that reducing MFN tariffs all the way to zero has a large additional impact on imports - above and beyond those of tariff reductions. As described in Section 5.3, an additional impact of eliminating tariffs seems intuitive, because zero MFN tariffs reduce frequency and rigor of border inspections, thereby expediting customs clearance and reducing

\footnotetext{
${ }^{51}$ Coefficients of other first-stage control variables, including RTA dummies, are reported in Table A1. Their statistical insignificance seems to suggest that RTA impacts in our sectors operate mainly through tariff reductions, with no significant additional effects resulting from tariff elimination or increased trade policy certainty.

${ }^{52}$ Other studies providing such estimates include Baier and Bergstrand (2001), Broda and Weinstein (2006), Kee et al. (2008) and Tokarick (2014). The latter two obtain estimates lower than ours in absolute value.

${ }^{53}$ Head and Mayer (2014) point out that the two align when exporters are marginal players without market power. Meanwhile, they note that an extreme case of high market power would be that of only one exporting country and use the narrow product category of Scottish whiskey as an example. With Scotland being its only producer, the elasticity of substitution across exporters would be zero, unlike the price elasticity of imports.
} 
goods' time spent in transit.

Our estimates suggest that tariff elimination - whether implemented because of ITA accession or unilaterally - will boost eligible imports by about 6-13 percent, with our preferred estimate from the machinery sample constituting the higher end of the range. ${ }^{54}$ Thus, making the final effort to reduce small tariffs, say from 1 to 0 percent, will achieve a much higher impact than reducing a high tariff by several percentage points without reaching zero.

Like tariff reduction, tariff elimination is especially important for intermediate goods. For intermediates, the impact of tariff elimination is estimated in the 14-18 percent range. For final goods, in contrast, our estimates suggest only up to a 5 percent trade increase in the preferred regression on the machinery sample; coefficients are smaller and insignificant on the ICT sample.

Strong policy implications arise from our confirmation of the existence of tariff elimination impacts. It generates a strong case for eliminating tariffs that are already low: Losing related tariff revenues would not have large fiscal implications, while trade gains could be substantial. To the extent that sectoral tariff elimination agreements at the WTO provide a credibility mechanism that allows governments to achieve such tariff elimination, they should be worthwhile pursuing. In particular, we would suspect the recently implemented ITA expansion to also have substantial impact. Tariff elimination in other sectors, such as machinery or chemicals - which have been proposed by some WTO members in the past - would likely also have trade expansion benefits beyond those of tariff reduction. Interpreted in reverse, our results suggest that reintroducing even moderate tariffs on products currently benefiting from zero tariffs could disproportionately hurt trade. Therefore, any studies exploring "trade war" scenarios would do well in paying attention to these non-linearities in tariff impacts.

Non-linearity of tariff impacts can help resolve some puzzles raised in previous literature. First, Feenstra (2008) examines, specifically for IT products, a question related to ours. He focuses on the tariff to import price pass-through and finds that tariff reductions for ITA goods have a highly magnified effect - of up to a factor of $22(!)$ - on their import prices. He suggests that the huge magnitude of this effect may result because ITA members' tariffs were already in the low single digits before accession, and thereby absolute price changes would nonetheless be moderate. Our results meanwhile indicate that these high estimates may rather be a result of non-linearity in the impact of tariff reductions. Elimination seems to have a distinctive additional impact in lowering trade costs, which could be passed on in the form of lower prices.

Second, Yi's (2003) model of value chain trade underscores that tariff reductions will have an especially high trade impact once fragmentation of production kicks in. To provide

\footnotetext{
${ }^{54}$ Regression coefficients on dummy variables, such as the zero tariff dummy and our ITA membership variables, express impacts in log units. These are very similar to percentage changes for values close to zero. The exact percentage change implied by any coefficient $b$ can be calculated as $\exp (b)-1$. The 6-13 percent range mentioned here is obtained from the estimates of the tariff elimination effect in Regressions 1 and 2 : $\exp (0.063)-1=6.5 \% ; \exp (0.121)-1=13 \%$.
} 
intuition for his model, Yi argues that tariff reductions in the 1980s and '90s were much more potent than those in 1960s and '70s. Our results suggest that the higher potency of tariff reduction in the 1980s and '90s could have partly been driven by higher incidence of tariffs elimination during this period.

\subsection{Commitment effect for importers}

The final layer on the import side quantifies whether tariff elimination brought larger benefits if implemented through hard-to-reverse WTO bindings under the ITA as compared to unilateral liberalization. For intermediate goods, this can spur additional trade integration, if higher trade policy certainty leads to stronger fragmentation via GVCs and therefore higher import flows. For final goods, higher trade policy certainty makes investments by exporters in distribution networks in ITA destinations less risky. As a result, exporters may have an incentive to redirect their exports toward ITA members and final goods imports of the latter may rise.

We find that ITA commitment effects had the largest impact on imports in passive signatories. This seems intuitive, because these countries did not have well-developed IT sectors before joining the ITA, unlike active signatories (Section 3). Our estimates suggest that ITA commitment effects boosted their intermediate imports by 26-60 percent, with our preferred estimate from the ICT sample forming the higher end of the range. As passive signatories integrated in a downstream position, their final goods imports did not respond strongly. The 7-14 percent impact in the all goods sample is thereby largely driven by intermediates.

A GVC narrative suggests that final ITA goods imports should have increased among active signatories after they moved downstream production stages to passive signatories. The importer commitment effect for active signatories indeed suggests that final goods imports increased more in active ITA signatories. The coefficient from the ICT sample indicates that exporters increased their ITA goods shipments to active signatories by 20 percent more than those of ICT goods. ${ }^{55}$ Evidence is weaker on the machinery sample. However, this composition effect is only a small part of the export benefits reaped by passive signatories, because it only quantifies relative shifts in trade between destinations. Trade increases across destinations are picked up by the exporter commitment effect.

\subsection{Commitment effects for exporters}

Exporter commitment effects reflect that ITA membership bolstered development of downstream ITA export sectors in passive signatories. Coefficients imply that passive signatories' ITA exports overall increased by 17-23 percent more than those of other ICT or machinery goods after ITA accession. This overall effect is largely driven by final goods

\footnotetext{
${ }^{55}$ To be exact, the coefficient measures this relative to the shares of shipments to ITA nonmembers. Thus, this statement would be correct if ITA and other ICT goods' imports had grown at the same rate in nonmember countries.
} 
wherein ITA exports outperformed the control groups by 26-40 percent. The effects remain significant, with broadly similar magnitude, even if Chinese exports are eliminated from the estimation sample. These findings resound with the literature on value chains, which emphasizes that initial GVC entrants most commonly join in downstream activities, because capabilities needed to perform downstream tasks, such as assembly, can be acquired most easily. ${ }^{56}$ Intermediate goods exports, which would signal an upstream value chain position, did not expand as strongly among passive signatories, as expected. Estimates are positive also for intermediate goods exports, but with low levels of statistical significance.

For active signatories' exports, ITA commitment effects are not very strong. Coefficients are statistically insignificant, suggesting that ITA exports evolved broadly in line with those of the control product groups. A likely reason seems that active signatories' IT export industries were already large and mature when these countries joined the agreement. While the ITA likely lowered costs for firms in active signatories (and thereby possibly motivated the sector to lobby for ITA), it did not spur their total export value. Indeed, there is weak evidence of a contraction in active signatories' final ITA exports, which again fits the narrative that expansions in production capacity centered in passive signatories.

\section{Extensions and Robustness}

This section presents four extensions and robustness checks. First, it explores to which extent the trade gains facilitated by the ITA were driven by the extensive margin. Second, it confirms that results based on our quasi-natural experiment sample mirror those of the baseline. Third, it demonstrates that results are robust to different ways of introducing the tariff reduction and elimination effects. Finally, it illustrates that country characteristics influenced how much passive signatories managed to benefit from the ITA.

\subsection{Extensive margin}

We follow Martincus et al. (2010) and Silva et al. (2014) and define the extensive margin as the share of tariff lines registering positive trade flows. This allows us to see whether the ITA induced exporters to broaden their product offering to any given destination country. Specifically, we calculate the number of tariff lines that are positively traded for each importer-exporter-year combination for ITA goods on the one hand, and for each of our two control sectors on the other hand. The share is then obtained by dividing the number of positively traded ITA goods by the total number of ITA goods, and likewise for the control sectors. As before, we again explore two estimation samples, ICT goods and machinery goods. Each of these estimation samples features two observations - one for ITA and one for the control sector - for each importer-exporter-year combination. We also calculate, in analog fashion, shares of positively traded intermediate and final goods for ITA and control sectors. Appendix Table A11 presents the sample means for various subsamples. Shares of

\footnotetext{
${ }^{56}$ Section II.C in WTO (2014) reviews this literature.
} 
Table 3: Extensive margin results

\begin{tabular}{|c|c|c|c|c|c|c|}
\hline \multirow{2}{*}{$\begin{array}{l}\text { Type of goods } \\
\text { Sample } \\
\text { Regression Set }\end{array}$} & \multicolumn{2}{|c|}{ All goods } & \multicolumn{2}{|c|}{ Intermediate } & \multicolumn{2}{|c|}{ Final } \\
\hline & $\begin{array}{l}\mathrm{ICT} \\
(1)\end{array}$ & $\begin{array}{c}\text { Machinery } \\
(2)\end{array}$ & $\begin{array}{l}\mathrm{ICT} \\
(3)\end{array}$ & $\begin{array}{l}\text { Machinery } \\
(4)\end{array}$ & $\begin{array}{l}\mathrm{ICT} \\
(5)\end{array}$ & $\begin{array}{l}\text { Machinery } \\
\quad(6)\end{array}$ \\
\hline \multicolumn{7}{|c|}{$\begin{array}{l}\text { Stage } 1 \text { (OLS). }{ }^{1} \text { Dependent variable: bilateral share of products with positive imports in a sector } \\
\text { See Appendix Table A2 for Stage } 1 \text { results. }\end{array}$} \\
\hline \multicolumn{7}{|c|}{ Stage 2 for importers (OLS). ${ }^{2}$ Dependent variable: importer-product-time FEs } \\
\hline $\begin{array}{l}\text { Commitment effect: } \\
\text { active ITA importers }\end{array}$ & $\begin{array}{c}0.010^{* * *} \\
(3.93)\end{array}$ & $\begin{array}{c}0.012^{* *} \\
(3.06)\end{array}$ & $\begin{array}{c}0.037^{* * *} \\
(3.96)\end{array}$ & $\begin{array}{c}0.049^{* * *} \\
(5.06)\end{array}$ & $\begin{array}{r}-0.014^{*} \\
(-2.01)\end{array}$ & $\begin{array}{l}-0.014^{*} \\
(-2.27)\end{array}$ \\
\hline $\begin{array}{l}\text { Commitment effect: } \\
\text { passive ITA importers }\end{array}$ & $\begin{array}{l}0.006^{+} \\
(1.80)\end{array}$ & $\begin{array}{c}0.014^{* *} \\
(2.61)\end{array}$ & $\begin{array}{c}0.035^{* * *} \\
(4.46)\end{array}$ & $\begin{array}{c}0.039^{* * *} \\
(3.68)\end{array}$ & $\begin{array}{l}-0.010 \\
(-1.38)\end{array}$ & $\begin{array}{l}0.003 \\
(0.44)\end{array}$ \\
\hline Observations & 7,558 & 7,616 & 7,090 & 7,428 & 7,350 & 7,420 \\
\hline Adjusted $R^{2}$ & 0.9349 & 0.8300 & 0.7568 & 0.6628 & 0.8641 & 0.8411 \\
\hline \multicolumn{7}{|c|}{ Stage 2 for exporters (OLS). ${ }^{3}$ Dependent variable: exporter-product-time FEs } \\
\hline $\begin{array}{l}\text { Commitment effect: } \\
\text { active ITA exporters }\end{array}$ & $\begin{array}{c}0.016^{* * *} \\
(6.19)\end{array}$ & $\begin{array}{c}0.027^{* * *} \\
(6.23)\end{array}$ & $\begin{array}{c}0.054^{* * *} \\
(5.26)\end{array}$ & $\begin{array}{c}0.061^{* * *} \\
(5.97)\end{array}$ & $\begin{array}{l}-0.009 \\
(-1.40)\end{array}$ & $\begin{array}{l}0.010^{*} \\
(2.03)\end{array}$ \\
\hline $\begin{array}{l}\text { Commitment effect: } \\
\text { passive ITA exporters }\end{array}$ & $\begin{array}{c}0.009^{* *} \\
(2.97)\end{array}$ & $\begin{array}{c}0.015^{* *} \\
(2.99)\end{array}$ & $\begin{array}{l}0.017^{*} \\
(2.29)\end{array}$ & $\begin{array}{l}0.014 \\
(1.56)\end{array}$ & $\begin{array}{c}0.007^{+} \\
(1.93)\end{array}$ & $\begin{array}{l}0.012^{*} \\
(2.43)\end{array}$ \\
\hline $\begin{array}{l}\text { Commitment effect } \\
\text { other than China }{ }^{4}\end{array}$ & $\begin{array}{c}0.009^{* *} \\
(2.94)\end{array}$ & $\begin{array}{c}0.015^{* *} \\
(2.96)\end{array}$ & $\begin{array}{l}0.016^{*} \\
(2.09)\end{array}$ & $\begin{array}{l}0.010 \\
(1.21)\end{array}$ & $\begin{array}{l}0.009^{*} \\
(2.45)\end{array}$ & $\begin{array}{l}0.013^{* *} \\
(2.59)\end{array}$ \\
\hline Observations & 7,602 & 7,716 & 6,358 & 7,444 & 7,164 & 7,296 \\
\hline Adjusted $R^{2}$ & 0.9253 & 0.7874 & 0.7306 & 0.5654 & 0.8870 & 0.8530 \\
\hline
\end{tabular}

Notes: $+,{ }^{*}, * *, * * *$ denote $10,5,1,0.1$ per cent significance levels, based on robust standard errors clustered by country-pairproduct combinations in the first-stage regressions and by importer-product or exporter-product combinations, respectively, in the second-stage regressions.

1 Given the change in dependent variable, there is no meaningful way here - in contrast to Table 2 - to control for the impact of preferential tariff reductions in stage 1. Stage 1 includes the other controls as before in Table 2: importer-exporter-product, import-product-time and exporter-product-time fixed effects, a "Both in WTO" dummy, separate dummies for exports of late joiners of the EU and US FTAs covered under these agreements, and regional trade agreement and common currency dummies. These results are in Appendix Table A2.

Additionally, unlike other tables, the extensive margin Stage 1 regressions are estimated by OLS. Note that Stage 1 regressions in other tables are estimated by Poisson estimation.

2 Regression includes importer-time, importer-product and product-time fixed effects.

3 Regression includes exporter-time, exporter-product and product-time fixed effects.

4 These coefficients are obtained from an exact analog regression that excludes China's exports from the sample. The commitment effect for passive ITA exporters is the only one to substantially vary as a result of such a sample modification. The full regression results from this restricted sample are available upon request.

5 The sectors are ITA goods, on the one hand, and other ICT or other Machinery goods, on the other hand. Thus there are two observations per country pair in a given year. 
tariff lines with positive trade flows vary between 0.10 to 0.40 depending on the subsample; they are typically larger for active signatories and increased over time within most subsamples.

We again apply our two-stage estimation technique. However, we eliminate tariff reduction and elimination effects from the regressions, because they lose meaning in light of the dependent variable now being the share of traded goods. ${ }^{57}$ In addition, we now estimate also the first-stage regression using OLS. ${ }^{58}$ Silva et al. (2014) present a simulations-based comparison of six estimation methods for fractional response data applied to the extensive margin of trade. They find that OLS performs better than log-linear, Poisson and negative binomial estimation. ${ }^{59}$

The results of our extensive margin regressions suggest that ITA facilitated a broadening of global trade relations along the lines of GVCs (Table 3). Active signatories integrated more in value chains both on the sourcing and the sales side. On the sourcing side, their importer commitment effect illustrates that they increased the share of ITA products imported from an average trade partner by around 1 percentage point. Again, we rely on cross-product variation for identification. Therefore, the coefficient depicts a relative change: it shows that the trade share of ITA increased by 1 percentage point more than that of control sectors. This is non-negligible, given a 0.15 average share for import activity of active signatories in 1996 (Appendix Table A11). Effects are driven by larger diversity among suppliers in intermediate good sourcing with an increase of around 4 percentage points relative to a 1996 share of 0.21. On the sales side, active signatories' exporter commitment effects likewise illustrate that ITA helped them boost the share of products exported by around 2 percentage points more than those in the control group. Again, this is driven by intermediates, which registered a relative increase of about 6 percentage points.

Passive signatories also diversified their trade patterns relatively more for ITA inputs. The effects on sourcing are similar to those found in active signatories. The share of goods imported rose by about 1 percentage point in ITA goods relative to control sectors, driven by a increase in the share of intermediates imported of close to 4 percentage points. Again, these increases are considerable compared to the initial shares traded in 1996. On the export side, passive signatories also broadened trade relationships in ITA goods more after ITA accession than those in other goods, by about 1 percentage point. In contrast with active signatories, this increase was driven more strongly by final goods in light of passive signatories' downstream position.

\footnotetext{
${ }^{57}$ Inclusion of tariffs in such a setting would require some measure of an average bilateral tariff. However, it is unclear whether one would include an average across traded or also non-traded lines, and how any trade weighing of such an average would be undertaken. Therefore, we rely in the extensive margin estimations we rely on our extensive set ofthese fixed effect controlss that take care of MFN tariffs and an rta RTA dummy that shouldto take care of average tariff preferences.

${ }^{58}$ Appendix Table A2 presents the complete first stage regression.

${ }^{59}$ They also find that OLS is outperformed by a Flex estimator proposed by them and the Papke-Wooldridge estimator (Papke and Wooldridge, 1996). However, those estimators cannot be implemented for our regression with three sets of high-dimensional fixed effects.
} 


\subsection{Quasi-natural experiment sample}

In Table 4, we present the results from our quasi-natural experiment of passive signatories. As these countries joined ITA "exogenously" to achieve a larger policy objective, this is an important robustness check to confirm that our baseline results are not suffering from endogeneity bias. The setup is analogue to the baseline, only that we eliminate from the second-stage sample all active signatories' observations. ${ }^{60}$

The results closely mirror those of the baseline, suggesting that our estimation strategy indeed forestalls endogeneity concerns. Among the importer-side effects, MFN tariff reduction and elimination effects both remain statistically significant, and for intermediate goods flows now suggest that impacts could be stronger. ITA importer commitment effects for passive signatories are also not much changed. On the exporter side, the commitment effects on the all goods sample are now slightly stronger. They seem to be driven also more by intermediate goods now, while final goods predominated more strongly in the baseline. However, these regressions also feature our lowest number of observations in light of the unavailable intermediate/final classification for many goods in addition to the limitation of the sample across exporters introduced here. Therefore some caution seems warranted in their interpretation.

\subsection{Lagged tariffs and interaction of tariff reduction and tariff elimination effects}

In this subsection, we summarize two further sensitivity analyses relating to tariff reduction and elimination effects. The first investigates the dynamic impacts of tariff reductions by gradually adding lagged tariff levels (Table 5). ${ }^{61}$ As Figure 1 illustrated, ITA signatories had already reduced their tariffs rapidly in the run up to accession. If these tariff reductions only had an impact on trade with a lag due to firms requiring time to adjust their export patterns, then their impact could be falsely attributed to our other effects. We present results from the sample covering all goods.

The results overall suggest that firms do not take much longer than a year to react to tariff reductions. For MFN tariff reductions, trade's response seems to be quite immediate, with contemporaneous coefficients virtually unchanged and the first lag statistically insignificant throughout. For the preferential tariff reduction effect, its first lag is significant statistically and close in magnitude to the contemporaneous tariff regressor. This suggests that for preferential tariff reductions somewhat more time may be needed for adjustment, as firms have to study eligibility and documentation requirements for new RTA preferences. These adjustments, however, seem to be complete by the second year, as coefficients on a second lag carry a counterintuitive positive sign.

\footnotetext{
${ }^{60}$ Results from two unreported versions, which depart from a first-stage regression on a sample excluding active signatories' imports (exports) and then estimate the second-stage importer (exporter) regression based thereon, are very similar.

${ }^{61}$ Appendix Table A3 presents the complete first stage regression.
} 
Table 4: Robustness: Quasi-natural experiment

(Restricted sample excluding active ITA signatories in the second stage)

\begin{tabular}{|c|c|c|c|c|c|c|}
\hline \multirow{2}{*}{$\begin{array}{l}\text { Type of goods } \\
\text { Sample } \\
\text { Regression Set }\end{array}$} & \multicolumn{2}{|c|}{ All goods } & \multicolumn{2}{|c|}{ Intermediate } & \multicolumn{2}{|c|}{ Final } \\
\hline & $\begin{array}{l}\mathrm{ICT} \\
(1)\end{array}$ & $\begin{array}{l}\text { Machinery } \\
\quad(2)\end{array}$ & $\begin{array}{c}\mathrm{ICT} \\
(3)\end{array}$ & $\begin{array}{c}\text { Machinery } \\
(4)\end{array}$ & $\begin{array}{c}\mathrm{ICT} \\
(5)\end{array}$ & $\begin{array}{c}\text { Machinery } \\
\text { (6) }\end{array}$ \\
\hline \multicolumn{7}{|c|}{ Stage 1 (PPML). ${ }^{1}$ Dependent variable: bilateral product-level imports } \\
\hline \multicolumn{7}{|c|}{ Stage 1 regressions are the same as in Table 2.} \\
\hline \multicolumn{7}{|c|}{ Stage 2 for importers (OLS). ${ }^{2}$ Dependent variable: importer-product-time FEs } \\
\hline MFN tariff reduction & $\begin{array}{l}-0.212 \\
(-0.98)\end{array}$ & $\begin{array}{c}-0.747^{* * *} \\
(-7.82)\end{array}$ & $\begin{array}{l}-0.214 \\
(-0.32)\end{array}$ & $\begin{array}{c}-1.034^{* *} \\
(-2.96)\end{array}$ & $\begin{array}{c}-0.687^{+} \\
(-1.79)\end{array}$ & $\begin{array}{l}-0.255 \\
(-1.03)\end{array}$ \\
\hline Tariff elimination effect & $\begin{array}{c}0.102^{* * *} \\
(4.16)\end{array}$ & $\begin{array}{c}0.160^{* * *} \\
(14.16)\end{array}$ & $\begin{array}{c}0.312^{* * *} \\
(4.67)\end{array}$ & $\begin{array}{c}0.243^{* * *} \\
(5.17)\end{array}$ & $\begin{array}{c}-0.0240 \\
(-0.64)\end{array}$ & $\begin{array}{c}0.0799^{*} \\
(2.29)\end{array}$ \\
\hline $\begin{array}{l}\text { Commitment effect: } \\
\text { passive ITA importers }\end{array}$ & $\begin{array}{c}0.0904^{*} \\
(2.26)\end{array}$ & $\begin{array}{c}0.0133 \\
(0.42)\end{array}$ & $\begin{array}{c}0.411^{* * *} \\
(4.07)\end{array}$ & $\begin{array}{c}0.221^{* *} \\
(2.96)\end{array}$ & $\begin{array}{c}0.0161 \\
(0.24)\end{array}$ & $\begin{array}{c}0.0286 \\
(0.45)\end{array}$ \\
\hline Observations & 238,930 & $1,130,605$ & 47,297 & 99,525 & 70,792 & 98,968 \\
\hline Adjusted $R^{2}$ & 0.7434 & 0.7217 & 0.7277 & 0.7673 & 0.7568 & 0.7343 \\
\hline \multicolumn{7}{|c|}{ Stage 2 for exporters (OLS). ${ }^{3}$ Dependent variable: exporter-product-time FEs } \\
\hline $\begin{array}{l}\text { Commitment effect: } \\
\text { passive ITA exporters }\end{array}$ & $\begin{array}{c}0.173^{* *} \\
(2.82)\end{array}$ & $\begin{array}{l}0.284^{* * *} \\
(6.34)\end{array}$ & $\begin{array}{l}0.312^{*} \\
(2.01)\end{array}$ & $\begin{array}{l}0.324^{* *} \\
(3.08)\end{array}$ & $\begin{array}{l}0.136 \\
(1.24)\end{array}$ & $\begin{array}{c}0.330^{* * *} \\
(3.37)\end{array}$ \\
\hline $\begin{array}{l}\text { Commitment effect } \\
\text { other than China }{ }^{4}\end{array}$ & $\begin{array}{l}0.144^{*} \\
(2.27)\end{array}$ & $\begin{array}{c}0.281^{* * *} \\
(6.02)\end{array}$ & $\begin{array}{l}0.289^{+} \\
(1.80)\end{array}$ & $\begin{array}{c}0.334^{* *} \\
(3.04)\end{array}$ & $\begin{array}{c}0.0968 \\
(0.85)\end{array}$ & $\begin{array}{c}0.291^{* *} \\
(2.93)\end{array}$ \\
\hline Observations & 194,665 & 760,091 & 34,548 & 77,512 & 59,277 & 77,708 \\
\hline Adjusted $R^{2}$ & 0.6759 & 0.6427 & 0.6987 & 0.6879 & 0.6571 & 0.6629 \\
\hline
\end{tabular}

Notes: $+,{ }^{*}, * *, * * *$ denote $10,5,1,0.1$ per cent significance levels, based on robust standard errors clustered by country-pairproduct combinations in the first-stage regressions and by importer-product or exporter-product combinations, respectively, in the second-stage regressions.

1 Regression includes importer-exporter-product, import-product-time and exporter-product-time fixed effects.

Additionally, all first-stage regressions include a "Both in WTO" dummy, separate dummies for exports of late joiners of the EU and US FTAs covered under these agreements, and regional trade agreement and common currency dummies. Given the extensive fixed effect controls, the coefficients of these controls are insignificant; these results are Appendix Table A1.

2 Regression includes importer-time, importer-product and product-time fixed effects.

3 Regression includes exporter-time, exporter-product and product-time fixed effects.

4 These coefficients are obtained from an exact analog regression that excludes China's exports from the sample. The commitment effect for passive ITA exporters is the only one to substantially vary as a result of such a sample modification. The full regression results from this restricted sample are available upon request. 
Table 5: Robustness: Lagged tariff reduction effects

\begin{tabular}{|c|c|c|c|c|c|c|}
\hline \multirow{2}{*}{$\begin{array}{l}\text { Type of goods } \\
\text { Regression Set }\end{array}$} & \multicolumn{6}{|c|}{ All goods } \\
\hline & $(1)$ & $(2)$ & $(3)$ & $(4)$ & $(5)$ & (6) \\
\hline \multicolumn{7}{|c|}{ Stage 1 (PPML). ${ }^{1}$ Dependent variable: bilateral product-level imports } \\
\hline Preferential tariff reduction & $\begin{array}{c}-1.150^{* * *} \\
(-3.66)\end{array}$ & $\begin{array}{c}-0.472^{*} \\
(-2.03)\end{array}$ & $\begin{array}{l}-0.808^{* *} \\
(-2.85)\end{array}$ & $\begin{array}{c}-0.288^{+} \\
(-1.76)\end{array}$ & $\begin{array}{c}-0.841^{* *} \\
(-2.92)\end{array}$ & $\begin{array}{l}-0.308^{*} \\
(-2.04)\end{array}$ \\
\hline Preferential tariff reduction,t-1 & & & $\begin{array}{l}-0.676^{*} \\
(-2.15)\end{array}$ & $\begin{array}{l}-0.294 \\
(-1.43)\end{array}$ & $\begin{array}{c}-1.058^{* * *} \\
(-3.78)\end{array}$ & $\begin{array}{c}-0.398^{* *} \\
(-2.63)\end{array}$ \\
\hline Preferential tariff reduction,t-2 & & & & & $\begin{array}{c}0.822^{* *} \\
(2.88)\end{array}$ & $\begin{array}{l}0.240 \\
(1.02)\end{array}$ \\
\hline Sum t to t-2 & $\begin{array}{c}-1.150^{* * *} \\
(-3.66)\end{array}$ & $\begin{array}{l}-0.472^{*} \\
(-2.03)\end{array}$ & $\begin{array}{c}-1.484^{* *} \\
(-2.91)\end{array}$ & $\begin{array}{c}-0.582+ \\
(-1.74)\end{array}$ & $\begin{array}{r}-1.077+ \\
(-1.66)\end{array}$ & $\begin{array}{l}-0.466 \\
(-1.05)\end{array}$ \\
\hline Observations & $8,120,335$ & $32,162,466$ & $7,232,615$ & $28,414,441$ & $6,697,866$ & $26,269,922$ \\
\hline$R^{2}$ & 0.9837 & 0.9867 & 0.9840 & 0.9870 & 0.9842 & 0.9872 \\
\hline \multicolumn{7}{|c|}{ Stage 2 for importers $(\mathrm{OLS}) .^{2}$ Dependent variable: importer-product-time FEs } \\
\hline MFN tariff reduction & $\begin{array}{l}-0.265 \\
(-1.47)\end{array}$ & $\begin{array}{c}-0.687^{* * *} \\
(-8.81)\end{array}$ & $\begin{array}{l}-0.189 \\
(-0.67)\end{array}$ & $\begin{array}{c}-0.666^{* * *} \\
(-5.78)\end{array}$ & $\begin{array}{l}-0.227 \\
(-0.71)\end{array}$ & $\begin{array}{c}-0.638^{* * *} \\
(-4.86)\end{array}$ \\
\hline MFN tariff reduction,t-1 & & & $\begin{array}{l}0.094 \\
(0.36)\end{array}$ & $\begin{array}{l}0.119 \\
(1.10)\end{array}$ & $\begin{array}{l}0.272 \\
(0.75)\end{array}$ & $\begin{array}{l}0.099 \\
(0.69)\end{array}$ \\
\hline MFN tariff reduction,t-2 & & & & & $\begin{array}{c}-0.847^{* *} \\
(-3.24)\end{array}$ & $\begin{array}{r}-0.211^{+} \\
(-1.93)\end{array}$ \\
\hline Sum t to t-2 & $\begin{array}{l}-0.265 \\
(-1.47)\end{array}$ & $\begin{array}{c}-0.687^{* * *} \\
(-8.81)\end{array}$ & $\begin{array}{l}-0.095 \\
(-0.46)\end{array}$ & $\begin{array}{c}-0.547^{* * *} \\
(-6.10)\end{array}$ & $\begin{array}{c}-0.801^{* * *} \\
(-3.41)\end{array}$ & $\begin{array}{c}-0.750^{* * *} \\
(-7.30)\end{array}$ \\
\hline Tariff elimination effect & $\begin{array}{c}0.063^{* * *} \\
(4.04)\end{array}$ & $\begin{array}{c}0.121^{* * *} \\
(14.75)\end{array}$ & $\begin{array}{c}0.049^{* *} \\
(3.16)\end{array}$ & $\begin{array}{c}0.092^{* * *} \\
(11.09)\end{array}$ & $\begin{array}{c}0.045^{* *} \\
(2.87)\end{array}$ & $\begin{array}{c}0.086^{* * *} \\
(10.27)\end{array}$ \\
\hline $\begin{array}{l}\text { Commitment effect: } \\
\text { active ITA importers }\end{array}$ & $\begin{array}{l}-0.024 \\
(-0.50)\end{array}$ & $\begin{array}{l}0.019 \\
(0.50)\end{array}$ & $\begin{array}{l}-0.046 \\
(-0.88)\end{array}$ & $\begin{array}{l}0.022 \\
(0.54)\end{array}$ & $\begin{array}{l}-0.079 \\
(-1.51)\end{array}$ & $\begin{array}{l}-0.005 \\
(-0.12)\end{array}$ \\
\hline $\begin{array}{l}\text { Commitment effect: } \\
\text { passive ITA importers }\end{array}$ & $\begin{array}{c}0.131^{* * *} \\
(3.38)\end{array}$ & $\begin{array}{c}0.0689^{*} \\
(2.23)\end{array}$ & $\begin{array}{c}0.116^{* *} \\
(2.95)\end{array}$ & $\begin{array}{c}0.083^{* *} \\
(2.62)\end{array}$ & $\begin{array}{c}0.112^{* *} \\
(2.75)\end{array}$ & $\begin{array}{c}0.093^{* *} \\
(2.80)\end{array}$ \\
\hline Observations & 367,521 & $1,729,821$ & 337,450 & $1,587,718$ & 316,462 & $1,491,014$ \\
\hline Adjusted $R^{2}$ & 0.8333 & 0.7999 & 0.8571 & 0.8247 & 0.8631 & 0.8309 \\
\hline \multicolumn{7}{|c|}{ Stage 2 for exporters (OLS). ${ }^{3}$ Dependent variable: exporter-product-time FEs } \\
\hline $\begin{array}{l}\text { Commitment effect: } \\
\text { active ITA exporters }\end{array}$ & $\begin{array}{l}0.003 \\
(0.05)\end{array}$ & $\begin{array}{l}-0.049 \\
(-0.98)\end{array}$ & $\begin{array}{l}0.019 \\
(0.31)\end{array}$ & $\begin{array}{l}-0.015 \\
(-0.30)\end{array}$ & $\begin{array}{l}0.022 \\
(0.37)\end{array}$ & $\begin{array}{l}-0.003 \\
(-0.06)\end{array}$ \\
\hline $\begin{array}{l}\text { Commitment effect: } \\
\text { passive ITA exporters }\end{array}$ & $\begin{array}{c}0.157^{* *} \\
(2.70)\end{array}$ & $\begin{array}{c}0.210^{* * *} \\
(4.95)\end{array}$ & $\begin{array}{l}0.124^{*} \\
(2.04)\end{array}$ & $\begin{array}{c}0.193^{* * *} \\
(4.36)\end{array}$ & $\begin{array}{r}0.118^{+} \\
(1.92)\end{array}$ & $\begin{array}{c}0.184^{* * *} \\
(4.07)\end{array}$ \\
\hline $\begin{array}{l}\text { Commitment effect } \\
\text { other than China }\end{array}$ & $\begin{array}{l}0.126^{*} \\
(2.06)\end{array}$ & $\begin{array}{c}0.216^{* * *} \\
(4.82)\end{array}$ & $\begin{array}{l}0.092 \\
(1.42)\end{array}$ & $\begin{array}{c}0.209^{* * *} \\
(4.42)\end{array}$ & $\begin{array}{l}0.078 \\
(1.18)\end{array}$ & $\begin{array}{c}0.199^{* * *} \\
(4.11)\end{array}$ \\
\hline Observations & 335,896 & $1,389,361$ & 287,440 & $1,172,376$ & 275,873 & $1,122,420$ \\
\hline Adjusted $R^{2}$ & 0.7336 & 0.7012 & 0.7981 & 0.7619 & 0.8123 & 0.7738 \\
\hline
\end{tabular}

Notes of Table 2 apply, including for ${ }^{1}$ through ${ }^{4}$. Stage 1 results with all controls are in Appendix Table A3. 
Estimates of tariff elimination and ITA commitment effects are not much affected by introducing lagged tariff reduction effects. This is unsurprising, because we obtain an overall magnitude of the tariff reduction effect closely comparable to the baseline when we add coefficients across lags. Tariff elimination effects are slightly reduced to a 5-10 percent range, with our preferred estimate again constituting the top end of the range. Passive signatories' ITA commitment effects are virtually unchanged on the import side. On the export side, the same holds true amid a slight reduction in magnitude.

The second sensitivity analysis explores how tariff reduction and tariff elimination effects may interact. ${ }^{62}$ The notion here is that the benefits of completely eliminating tariffs may be higher when this is done starting from a low tariff rather than a high tariff level (after tariff reduction effects are accounted for). To test this, we add an interaction of the tariff elimination dummy with the country's average tariff for the good in question across all years in our sample before the tariff became zero. The interaction coefficient is negative, though generally statistically insignificant (Appendix Table A10). Thus, there is weak evidence that the tariff elimination effect may indeed be higher for countries starting from low "nuissance" tariffs.

\subsection{Heterogeneity of ITA export commitment effects alongside country characteristics}

This section explores whether countries with certain characteristics reaped more trade benefits from ITA than others in fostering an IT export sector. We focus the discussion on the group of passive signatories. To quantify country circumstances we consider four determinants that are often mentioned in the global value chain literature as important for achieving GVC participation. They are geographical remoteness, education levels, the general business environment, and institutions. For remoteness, we devise a custom ITAspecific measure quantifying the distance from large ITA importers; this measure attributes greater weight to distances from those importers that import large quantities of ITA goods. For landlocked countries, we refine this measure further by including a multiplicative penalty obtained by dividing the countries' export costs per container by that of the most proximate coastal country. Education is proxied by secondary school completion rates (Prati et al., 2013). We use control of corruption (from the World Bank's World Governance Indicators) as a proxy for the overall business environment; Breen and Gillanders (2012) have shown these two variables to be highly correlated. Finally, institutions are proxied by the rule of law, taken from the same source.

We interact these determinants with the ITA export commitment effects for both active and passive exporters and add these interactions to Regression 1 in Table 2. We then combine the regression results and percentile values of the determinants for passive signatories in the year 2010 to compute Table 6 presented here. ${ }^{63}$

ITA's trade benefits for passive signatories do vary with country characteristics, but

\footnotetext{
${ }^{62}$ We thank an anonymous referee for the suggestion.

${ }^{63}$ The regression coefficients underlying Table 6 are reported Appendix Table A9.
} 
Table 6: Heterogeneity of ITA export commitment effects for passive signatories

\begin{tabular}{ccccc}
\hline \multicolumn{2}{l}{ Stage 2 for exporters $(\mathrm{OLS}){ }^{1}{ }^{1}$ Dependent variable: $^{2}$ exporter-product-time FEs } & \\
\hline Interaction Variable & Remoteness $^{2}$ & Education & Business environment & Rule of law \\
10th percentile & $0.181^{* *}$ & $0.157^{+}$ & 0.118 & 0.134 \\
25th percentile & $0.176^{* *}$ & $0.156^{+}$ & $0.124^{+}$ & $0.136^{+}$ \\
Median & $0.162^{* *}$ & $0.124^{*}$ & $0.136^{*}$ & $0.139^{*}$ \\
75th percentile & 0.092 & 0.092 & $0.161^{*}$ & $0.146^{*}$ \\
90th percentile & 0.084 & 0.078 & $0.186^{+}$ & 0.151 \\
\hline
\end{tabular}

Notes: Appendix Table A9 contains the underlying regression coefficients. Stage 1 regression is the same as in Regression 1 in Table 2.

$+, *, * *, * * *$ denote 10, 5, 1, 0.1 per cent significance levels, based on robust standard errors clustered by country-pair-product combinations in the first-stage regressions and by importer-product or exporter-product combinations, respectively, in the second-stage regressions. The figures in the tables are computed from percentile-specific interaction variable values in year 2010 and coefficients for passive signatories. See Appendix Table A9 for more details.

${ }^{1}$ Regression includes exporter-time, exporter-product and product-time fixed effects.

${ }^{2}$ Remoteness to world ITA goods import markets; see main text and Appendix Table A9 for further explanation.

maybe less than one would expect. Geographical remoteness seems to be the strongest impediment to leveraging ITA membership to develop IT exports. For the upper quartile of most remote countries, the ITA exporter commitment effect roughly halves and becomes statistically insignificant. Among policy variables, improvements in the business environment seem to go some way toward leveraging ITA, while better rule of law has a quite subdued impact. Regarding education, we find that passive signatories with lower education levels saw their ITA exports rise more strongly. This result is likely related to initial GVC integration in downward stages requiring large amounts of unskilled labor for assembly. However, higher education would likely be required later to achieve quality upgrading within GVCs. Hence, we interpret these results as being broadly consistent with the GVC literature surveyed in WTO (2014), which suggests that broad reforms are needed to create a favorable environment in which GVC participation can be achieved and deepened.

\section{Conclusion}

We show that tariff elimination under the ITA had large trade effects because it was instituted in a non-discriminatory and durable fashion. Non-discriminatory trade policies have been studied less than discriminatory policies, partly because identifying trade effects of non-discriminatory policies is more challenging if one wants to comprehensively control for multilateral resistance (Anderson and Van Wincoop, 2003) and endogeneity concerns. The WTO Information Technology Agreement (ITA) provides a unique setting to overcome these challenges. A quasi-natural experiment of a subset of "passive" signatories can allay endogeneity concerns, becaue these countries joined the agreement as an unavoidable by product of pursuing a larger policy objective. Use of product-level data, and the ITA's partial coverage of the IT sector, gives us a control group of very comparable ICT products 
for identification.

Notably we find that impacts of tariff changes are non-linear. There is a sizable bonus to a complete elimination of tariffs, as it makes customs inspections less frequent and burdensome, reducing traders' costs. In addition, certainty of trade policies, as achieved through WTO tariff bindings, results in another layer of benefits. This commitment effect also affects exports, with investment and firm location/sourcing decisions likely playing an important role. Import tariff elimination can thereby help in developing export industries - an angle which gravity literature has thus far neglected. Commitment effects for exports are found to be most important for a subset of largely developing countries (our passive signatory group). These countries were able to leverage ITA membership to develop downstream export activities. Whether similar impacts can be found for sectors other than the IT and machinery sectors is a question for future research. But it would not seem unreasonable to believe so, as long as tariffs are durably eliminated in a non-discriminatory fashion.

Our paper has implications, on the one hand, for gravity methodologies aiming to quantify trade agreements' impacts and, and on the other hand, for policy.

With regards to gravity methodology, tariff data should be integrated directly into the analysis. Doing so produces a wealth of new policy-relevant information by returning several layers of impacts. It shows that there is a premium to complete tariff elimination, especially for goods with high value chain integration potential, as suggested by the border administration and time in trade literatures. Our layered structure also allows dummy variables of trade agreement membership to be interpreted as commitment effects. This is an important advantage compared to many traditional gravity studies of trade agreements, in which a single membership dummy is introduced and captures the impact of a host of policy changes.

With regards to policy, we show that tariff elimination can cause considerable trade expansion, particularly if backed by strong commitments convincing agents of its durability. In instances where tariffs are already low, their elimination could return large trade benefits with only small fiscal revenue losses. Policymakers should bear in mind that there seem to be synergies between the overall business environment and the gains from durable tariff elimination. Therefore, complementary reforms are often necessary to fully reap the benefits of durable tariff elimination. Finally, it is important to safeguard zero tariffs wherever they have been achieved. 


\section{References}

Advisory Committee for Trade Policy and Negotiations (ACTPN), 2004. U.S.-Central America Free Trade Agreement: Report of the Advisory Committee for Trade Policy Negotiations. https://ustr.gov/archive/assets/Trade_Agreements/Regional/CAFTA/DR_ Reports/asset_upload_file6_3318.pdf.

Agnosteva, D. E., Anderson, J. E., Yotov, Y. V., 2014. Intra-national trade costs: Measurement and aggregation. Working Paper No. 19872, National Bureau of Economic Research.

Anderson, J. E., Van Wincoop, E., 2003. Gravity with Gravitas: A Solution to the Border Puzzle. The American Economic Review 93 (1), 170-192.

Anderson, J. E., Yotov, Y. V., 2010a. Specialization: Pro- and Anti-globalizing, 1990-2002. Working Paper No. 16301, National Bureau of Economic Research.

Anderson, J. E., Yotov, Y. V., 2010b. The Changing Incidence of Geography. American Economic Review 100 (5), 2157-86.

Anderson, M., Mohs, J., 2010. The Information Technology Agreement: An Assessment of World Trade in Information Technology Products. Journal of International Commerce and Economics 3, 109-154.

Antràs, P., Helpman, E., 2008. Contractual Frictions and Global Sourcing. In: Helpman, E., Verdier, T., Marin, D. (Eds.), The Organization of Firms in a Global Economy. Harvard University Press, Cambridge, MA.

Antràs, P., Staiger, R. W., 2012. Offshoring and the role of trade agreements. The American Economic Review 102 (7), 3140-3183.

ASYCUDA, 2017. Asycuda user countries, territories and regions. http://new. asycuda. org/asycuda-user-countries.html, accessed: 2018-02-12.

Augier, P., Gasiorek, M., Lai Tong, C., 2005. The impact of rules of origin on trade flows. Economic Policy 20 (43), 568-624.

Bagwell, K., Bown, C. P., Staiger, R. W., 2016. Is the WTO passé? Journal of Economic Literature 54 (4), 1125-1231.

Baier, S. L., Bergstrand, J. H., 2001. The growth of world trade: tariffs, transport costs, and income similarity. Journal of International Economics 53 (1), 1-27.

Baier, S. L., Bergstrand, J. H., 2004. Economic determinants of free trade agreements. Journal of International Economics 64 (1), 29-63.

Baier, S. L., Bergstrand, J. H., 2007. Do free trade agreements actually increase members' international trade? Journal of International Economics 71 (1), 72-95.

Baldwin, R., Taglioni, D., 2007. Trade effects of the euro: A comparison of estimators. Journal of Economic Integration 22 (4), 780-818. 
Bas, M., Mayer, T., Thoenig, M., 2017. From micro to macro: demand, supply, and heterogeneity in the trade elasticity. Journal of International Economics 108, 1-19.

Bora, B., Liu, X., 2010. Evaluating the Impact of the WTO Information Agreement. In: Findlay, C., Pangestu, M., Parsons, D. (Eds.), Light the Lamp: Papers on World Trade and Investment in Memory of Bijit Bora. World Scientific. Hackensack, NJ.

Breen, M., Gillanders, R., 2012. Corruption, institutions and regulation. Economics of Governance 13 (3), 263-285.

Bridgman, B., 2012. The rise of vertical specialization trade. Journal of International Economics 86 (1), 133-140.

Broda, C., Weinstein, D. E., 2006. Globalization and the Gains from Variety. The Quarterly Journal of Economics 121 (2), 541-585.

Caliendo, L., Feenstra, R. C., Romalis, J., Taylor, A. M., December 2015. Tariff reductions, entry, and welfare: Theory and evidence for the last two decades. Working Paper No. 21768, National Bureau of Economic Research.

Clausing, K. A., 2001. Trade creation and trade diversion in the Canada-United States Free Trade Agreement. Canadian Journal of Economics/Revue canadienne d'économique 34 (3), 677-696.

Commission of the European Communities, November 2001. Regular Report on Bulgaria's Progress Towards Accession. https://ec.europa.eu/neighbourhood-enlargement/ sites/near/files/archives/pdf/key_documents/2001/bu_en.pdf, retrieved 01February-2018.

Connor, J., 2014. Price-fixing overcharges: Revised 3rd edition. Mimeo, Purdue University.

De Wulf, L., 2005. Strategy for customs modernization. In: De Wulf, L., Sokol, J. B. (Eds.), Customs Modernization Handbook. World Bank Publications. Washington, D.C.

Djankov, S., Freund, C., Pham, C. S., 2010. Trading on time. The Review of Economics and Statistics 92 (1), 166-173.

Dreyer, I., Hindley, B., 2008. Trade in Information Technology Goods: Adapting the ITA to 21st Century Technological Change. Working Paper No. 06/2008, European Centre for International Political Economy.

Egger, P. H., Nigai, S., 2015. Structural gravity with dummies only: Constrained ANOVAtype estimation of gravity models. Journal of International Economics 97 (1), 86-99.

Eicher, T. S., Henn, C., 2011. In search of WTO trade effects: Preferential trade agreements promote trade strongly, but unevenly. Journal of International Economics 83 (2), 137-153.

Eicher, T. S., Henn, C., Papageorgiou, C., 2012. Trade creation and diversion revisited: Accounting for model uncertainty and natural trading partner effects. Journal of Applied Econometrics 27 (2), 296-321. 
Feenstra, R. C., 2008. Offshoring in the global economy. Ohlin Lecture at the Stockholm School of Economics, September 17-18.

Frazer, G., Van Biesebroeck, J., 2010. Trade Growth under the African Growth and Opportunity Act. The Review of Economics and Statistics 92 (1), 128-144.

Freund, C., Ornelas, E., 2010. Regional trade agreements. Annual Review of Economics 2 (1), $139-166$.

Freund, C., Pierola, M. D., 2015. Export superstars. Review of Economics and Statistics 97 (5), 1023-1032.

Gawande, K., Hoekman, B., Cui, Y., 2011. Determinants of trade policy responses to the 2008 financial crisis. World Bank Policy Research Working Paper No. 5862.

Groppo, V., Piermartini, R., 2014. Trade policy uncertainty and the WTO. Working Paper No. ERSD-2014-23, World Trade Organization.

Grossman, G. M., Helpman, E., 1994. Protection for Sale. American Economic Review 84 (4), $833-850$.

Hakobyan, S., 2013. GSP expiration and declining exports from developing countries. Mimeo.

Handley, K., Limão, N., 2013. Policy Uncertainty, Trade and Welfare: Theory and Evidence for China and the US. Working Paper No. 19376, National Bureau of Economic Research.

Handley, K., Limão, N., 2015. Trade and investment under policy uncertainty: theory and firm evidence. American Economic Journal: Economic Policy 7 (4), 189-222.

Harrison, G., Rutherford, T., Tarr, D., 1997. Quantifying the Uruguay Round. The Economic Journal 107 (444), 1405-1430.

Head, K., Mayer, T., 2014. Chapter 3 - Gravity Equations: Workhorse, Toolkit, and Cookbook. Vol. 4 of Handbook of International Economics. Elsevier, pp. 131-195.

Heid, B., Larch, M., Yotov, Y. V., 2017. Estimating the Effects of Non-discriminatory Trade Policies within Structural Gravity Models. Working Paper No. 6735, CESifo Working Paper.

Helpman, E., Melitz, M., Rubinstein, Y., 2008. Estimating trade flows: Trading partners and trading volumes. The Quarterly Journal of Economics 123 (2), 441-487.

Hintsa, J., Männistö, T., Hameri, A.-P., Thibedeau, C., Sahlstedt, J., Tsikolenko, V., Finger, M., Granqvist, M., 2011. Customs risk management (crim): A survey of 24 WCO member administrations. Study for World Customs Organization (WCO). Lausanne, Switzerland on 28 .

Hoekman, B., Martin, W., Mattoo, A., 2010. Conclude Doha: It matters! World Trade Review 9 (3), 505-530. 
Hummels, D. L., Schaur, G., 2013. Time as a trade barrier. The American Economic Review 103 (7), 2935-2959.

International Trade Administration, November 2004. U.S.-Morocco Free Trade Agreement Key Market Access Results and Benefits. https://www.trade.gov/mas/ian/build/ groups/public/@tg_ian/documents/webcontent/tg_ian_002534.pdf, Retrieved 01February-2018.

Joseph, K., Parayil, G., 2006. Trade liberalization and digital divide: An analysis of the Information Technology Agreement of WTO.

Keck, A., Lendle, A., 2012. New evidence on preference utilization. World Trade Organization Staff Working Paper No. ERSD-2012-12.

Kee, H. L., Nicita, A., Olarreaga, M., 2008. Import demand elasticities and trade distortions. The Review of Economics and Statistics 90 (4), 666-682.

Kuenzel, D. J., 2018. WTO Tariff Commitments and Temporary Protection: Complements or Substitutes? Working Paper No. 2018-001, Wesleyan University, Department of Economics.

Lee, J.-W., Swagel, P., 1997. Trade barriers and trade flows across countries and industries. Review of Economics and Statistics 79 (3), 372-382.

Liang, W., 2007. China's WTO commitment compliance. A case study of the US-China semiconductor trade dispute. In: Zeng, K. (Ed.), China's foreign trade policy: the new constituencies. Routledge, Ch. 7, pp. 101-117.

Maggi, G., Rodriguez-Clare, A., 2000. Import penetration and the politics of trade protection. Journal of International Economics 51 (2), 287-304.

Mann, C., Liu, X., 2009. The information technology agreement: sui generis or model stepping stone? In: Baldwin, R., Low, P. (Eds.), Multilateralizing Regionalism: Challenges for the Global Trading System. Cambridge University Press, Cambridge, pp. 182-216.

Martincus, C. V., Carballo, J., Graziano, A., 2015. Customs. Journal of International Economics, 119-137.

Martincus, C. V., Estevadeordal, A., Gallo, A., Luna, J., 2010. Information barriers, export promotion institutions, and the extensive margin of trade. Review of World Economics 146 (1), 91-111.

Moffatt, M., 2016. Making it Simple: Boosting Canadian Competitiveness through Selective Tariff Elimination. Mowat Centre.

Orefice, G., Rocha, N., 2014. Deep integration and production networks: An empirical analysis. The World Economy 37 (1), 106-136. 
Organisation for Economic Co-operation and Development, 2003. A proposed classification of ICT goods. OECD Working Party on Indicators for the Information Society, OECD, Paris.

Organisation for Economic Co-operation and Development, 2011. OECD Guide to Measuring the Information Society 2011. Paris: OECD Publishing.

Ornelas, E., Turner, J. L., 2008. Trade liberalization, outsourcing, and the hold-up problem. Journal of International Economics 74 (1), 225-241.

Osnago, A., Piermartini, R., Rocha, N., 2015. Trade policy uncertainty as barrier to trade. Working Paper No. 2015-05, World Trade Organization.

Osnago, A., Rocha, N., Ruta, M., 2016. Do Deep Trade Agreements Boost Vertical FDI? The World Bank Economic Review.

Papke, L. E., Wooldridge, J. M., 1996. Econometric Methods for Fractional Response Variables With an Application to 401(k) Plan Participation Rates. Journal of Applied Econometrics, 619-632.

Prati, A., Onorato, M. G., Papageorgiou, C., 2013. Which Reforms Work and under What Institutional Environment? Evidence from a New Data Set on Structural Reforms. Review of Economics and Statistics 95 (3), 946-968.

Rose, A. K., 2004. Do WTO members have more liberal trade policy? Journal of International Economics 63 (2), 209-235.

Rose, A. K., Lockwood, B., Quah, D., 2000. One money, one market: The effect of common currencies on trade. Economic Policy, 9-45.

Silva, J. S., Tenreyro, S., 2006. The log of gravity. The Review of Economics and Statistics 88 (4), 641-658.

Silva, J. S., Tenreyro, S., Wei, K., 2014. Estimating the extensive margin of trade. Journal of International Economics 93 (1), 67-75.

Sturgeon, T. J., Memedovic, O., 2010. Mapping global value chains: Intermediate goods trade and structural change in the world economy. Working Paper No. 05/2010, United Nations Industrial Development Organization.

Subramanian, A., Wei, S.-J., 2007. The WTO promotes trade, strongly but unevenly. Journal of International Economics 72 (1), 151-175.

Tang, M.-K., Wei, S.-J., 2009. The value of making commitments externally: Evidence from WTO accessions. Journal of International Economics 78 (2), 216-229.

Tapp, S., 2007. Understanding Rules of Origin: A Critical Review of the Literature. Department of Finance, Economic and Fiscal Policy Branch. 
Tokarick, S., 2014. A method for calculating export supply and import demand elasticities. The Journal of International Trade \& Economic Development 23 (7), 1059-1087.

Trefler, D., 1993. Trade liberalization and the theory of endogenous protection: an econometric study of US import policy. Journal of Political Economy, 138-160.

United States International Trade Commission, 2004. US-Central America-Dominican Republic Free Trade Agreement: Potential Economywide and Selected Sectoral Effects. https://www.usitc.gov/publications/332/pub3717.pdf.

United States International Trade Commission, 2006. US-Peru Trade Promotion Agreement: Potential Economy-wide and Selected Sectoral Effects.

United States Trade Representative (USTR), March 2004. Zoellick Joins Launching of U.S.-Bahrain FTA Congressional Caucus. https://ustr.gov/archive/Document_ Library/Press_Releases/2004/March/Zoellick_Joins_Launching_of_US-Bahrain_ FTA_Congressional_Caucus.html, retrieved 01-February-2018.

United States Trade Representative (USTR), May 2009. United States-Panama Trade Promotion Agreement, Statement of Everett Eissenstat (Assistant United States Trade Representative for the Americas) before the Committee on Finance, United States Senate. https: //www.finance. senate.gov/imo/media/doc/052109eetest.pdf, retrieved 01-February2018.

Villarreal, A. M., February 2014. The U.S.-Colombia Free Trade Agreement: Background and Issues. CRS Report for Congress. Congressional Research Service. https://fas . org/ sgp/crs/row/RL34470.pdf, retrieved 01-February-2018.

Wiese, R., Grant, L., Smyth, F., 2014. Zero duty does not equal zero risk. http://www. hunthunt.com.au/SiteMedia/W3SVC1265/Uploads/Documents/CGT\%2014-09-16.pdf, accessed on 16/11/2016.

World Trade Organization (WTO), 2012. 15 Years of the Information Technology Agreement. Report, World Trade Organization.

World Trade Organization (WTO), 2014. World Trade Report 2014 - Trade and Development: Recent Trends and the Role of the WTO. Report, World Trade Organization.

World Trade Organization (WTO), 2017. 20 Years of the Information Technology Agreement. Report, World Trade Organization.

Yeats, A. J., 2001. Just how big is global production sharing. In: in S. Arndt and H. Kierzkowski (eds), Fragmentation: New Production Patterns in the World.

Yi, K.-M., 2003. Can vertical specialization explain the growth of world trade? Journal of Political Economy 111 (1), 52-102.

Yotov, Y. V., Piermartini, R., Monteiro, J.-A., Larch, M., 2016. An advanced guide to trade policy analysis: The structural gravity model. World Trade Organization. 


\section{Annex I: Evidence on the quasi-natural experiment nature of "passive" signato- ries' ITA accessions}

This annex provides evidence to support our claim that a series of ITA late signatories primarily joined the ITA as a price for achieving a larger policy objective, and thereby constitute a quasi-natural experiment. We present the evidence grouped by each of the larger policy objectives (WTO accession, EU accession, and accession to a free trade agreement with the U.S.).

First, we identify countries that joined the ITA primarily as a prerequisite of WTO accession. Note that in WTO accession negotiations trade-related demands of all current WTO members have to be met by a candidate country. This gives existing members the power to insist on ITA membership as a precondition for WTO membership. As a result, all 15 countries that acceded to the WTO since ITA came into force had ITA commitments added to their Protocols of Accession. Likewise, all 15 countries were given the option to join the ITA already during but before conclusion of their WTO accession negotiations, as reported in WTO (2012). Since all these 15 countries were in WTO accession negotiations in 1996, they could therefore have become founding members of the ITA, but only Estonia and Chinese Taipei used this opportunity. ${ }^{64}$ The remaining 13 countries joined the ITA between 1999 and 2006, around the time of their WTO accession. For these, WTO (2012) highlights that becoming ITA signatories for the countries has been "mostly the result of a process where [ITA] participants have encouraged those in the process of acceding [to the WTO] to join the ITA as a part of their accession package". Thus we deem that for these 13 countries the main motivation to join the ITA was WTO accession rather than the ITA in its own right. ${ }^{65}$ We also looked for further country-specific evidence to reconfirm. For instance, for China, Liang (2007) argues that industry in the country was skeptical about ITA membership when President Jiang Zemin made an unexpected announcement at the 1997 APEC summit with President Clinton that China would join the ITA. The announcement served to improve trade relations with the United States and other trading partners and effectively accelerated China's WTO membership. China ultimately joined the ITA only in 2003 upon its accession to the WTO as required by the accession protocols.

Second, ITA membership includes the 12 countries that joined the EU in 2004 and 2007. We list five of these as active signatories: In addition to the above-mentioned Estonia, four chose to become ITA founding members long before EU membership (the Czech Republic, Poland, Romania, and the Slovak Republic). We classified the remaining seven countries as passive signatories. Two - Latvia and Lithuania - joined the ITA due to commitments in their WTO Accession Protocols in 1999. For the other five (Bulgaria, Cyprus, Hungary, Malta, and Slovenia), ITA accession was driven by the requirement to harmonize their trade policy with that of the EU as part of the EU accession process. Indeed, Hungary and Malta joined

\footnotetext{
${ }^{64}$ Both are ITA founding signatories (March 1997), but their accession to the WTO took place only in 1999 and 2001, respectively.

${ }^{65}$ In contrast, Estonia and Chinese Taipei enter our data as active signatories.
} 
the ITA in 2004 and Bulgaria in 2007, upon their EU accession. ${ }^{66}$ Slovenia and Cyprus joined the ITA in 2000, four years before the EU enlargement. To determine their motivation for joining the ITA, we conducted interviews with the WTO Secretariat staff as well as mission representatives in Geneva. A representative of the Permanent Mission of Cyprus wrote: "Indeed, in as far as Cyprus is concerned, accession to the ITA was definitely related to its accession process to the EU. During this process, Cyprus had to fully harmonise with the 'acquis communautaire', just like all the other candidate countries. Thus, becoming an ITA member was strongly encouraged and supported by the EU, both during the preparation of the tables/lists and the last stages of the accession itself in the WTO context."

Third, we identify a group of countries that joined the ITA in order to obtain a preferential trade agreement with the United States, as suggested by WTO (2012): "Several WTO members have also joined the ITA, which can partly be explained by a US policy that has systematically encouraged partners negotiating a free-trade agreement with the United States to also join the ITA. These include, for example, the Dominican Republic, Guatemala, Honduras, Nicaragua and Panama." There is indeed evidence that these five countries, but also Bahrain, Colombia, Morocco and Peru, joined the ITA as a precondition for a free trade agreement with the United States. For example, USITC (2006) states: "As a result of the TPA [Trade Promotion Agreement with the United States], Peru will become a signatory to the WTO ITA, which removes tariff and nontariff barriers to information technology (IT) products". Similarly, the Dominican Republic joined the ITA as part of the Dominican Republic-Central America-United States Free Trade Agreement (CAFTA-DR), as suggested for instance by the report of the United States Advisory Committee for Trade Policy and Negotiations (ACTPN, 2004): "The ACTPN is particularly pleased that the Dominican Republic, as part of these negotiations, will become a member of the WTO Information Technology Agreement, which provides for duty-free treatment of information technology products. This has been a key objective of U.S. high-tech industries." Similarly, Guatemala, Honduras and Nicaragua committed to join the ITA under the CAFTA-DR (USITC, 2004, p. 133), and Colombia agreed to join the ITA under the U.S.-Colombia RTA provisions (Villarreal, 2014). Negotiations of the free trade agreement between the U.S. and Bahrain had ITA membership of Bahrain as an early negotiation outcome (USTR, 2004). For Morrocco, the International Trade Administration of the U.S. Department of Commerce lists the country's commitment to join the ITA under the U.S.-Morocco FTA as one of the key opportunities coming from the agreement (International Trade Administration, 2004). Regarding Panama, the Assistant USTR for the Americas stated before the U.S. Senate Committee on Finance that Panama's agreement to join the ITA during free trade agreement negotiations benefits the IT products sector of the U.S. (USTR, 2009). Panama joined the ITA in June 1998 while it signed its FTA with the U.S. in June 2007; ITA membership was one of the first conditions to advance FTA negotiations.

\footnotetext{
${ }^{66}$ This process is outlined, for example, in the Commission of the European Communities (2001) report on Bulgaria's progress towards EU accession: "In February 2001 Bulgaria submitted its list of commitments concerning tariff reductions on IT products and the list was approved by the WTO. At present the formal decision by the committee on the accession of Bulgaria to the ITA is expected."
} 


\section{Appendix}

\section{Appendix Tables}

Table A1: Complete first-stage regression of Tables 2 and 4

\begin{tabular}{|c|c|c|c|c|c|c|}
\hline \multirow{2}{*}{$\begin{array}{l}\text { Type of goods } \\
\text { Sample } \\
\text { Regression Set }\end{array}$} & \multicolumn{2}{|c|}{ All goods } & \multicolumn{2}{|c|}{ Intermediate } & \multicolumn{2}{|c|}{ Final } \\
\hline & $\begin{array}{l}\text { ICT } \\
(1)\end{array}$ & $\begin{array}{c}\text { Machinery } \\
\text { (2) }\end{array}$ & $\begin{array}{l}\text { ICT } \\
(3)\end{array}$ & $\begin{array}{c}\text { Machinery } \\
\text { (4) }\end{array}$ & $\begin{array}{l}\text { ICT } \\
(5)\end{array}$ & $\begin{array}{c}\text { Machinery } \\
\text { (6) }\end{array}$ \\
\hline \multicolumn{7}{|c|}{ Stage 1 (PPML). ${ }^{1}$ Dependent variable: bilateral product-level imports } \\
\hline $\begin{array}{l}\text { Preferential tariff reduction } \\
\ln (1+\text { tariff })\end{array}$ & $\begin{array}{c}-1.150^{* * *} \\
(-3.66)\end{array}$ & $\begin{array}{l}-0.472^{*} \\
(-2.03)\end{array}$ & $\begin{array}{l}-1.608^{*} \\
(-2.37)\end{array}$ & $\begin{array}{c}-0.582^{+} \\
(-1.66)\end{array}$ & $\begin{array}{l}-0.601 \\
(-1.57)\end{array}$ & $\begin{array}{l}-0.533 \\
(-1.15)\end{array}$ \\
\hline Exporter late EU signatory ${ }^{2}$ & $\begin{array}{l}0.081 \\
(0.83)\end{array}$ & $\begin{array}{l}0.068 \\
(1.09)\end{array}$ & $\begin{array}{l}0.059 \\
(0.30)\end{array}$ & $\begin{array}{l}0.163 \\
(1.50)\end{array}$ & $\begin{array}{l}0.166 \\
(1.33)\end{array}$ & $\begin{array}{c}0.353^{* *} \\
(2.58)\end{array}$ \\
\hline Exporter late US-FTA signatory ${ }^{2}$ & $\begin{array}{l}-0.002 \\
(-0.03)\end{array}$ & $\begin{array}{l}-0.018 \\
(-0.38)\end{array}$ & $\begin{array}{l}-0.144 \\
(-1.12)\end{array}$ & $\begin{array}{l}-0.025 \\
(-0.21)\end{array}$ & $\begin{array}{l}-0.000 \\
(-0.00)\end{array}$ & $\begin{array}{l}-0.111 \\
(-1.64)\end{array}$ \\
\hline RTA & $\begin{array}{l}0.022 \\
(0.39)\end{array}$ & $\begin{array}{l}0.022 \\
(0.50)\end{array}$ & $\begin{array}{l}-0.029 \\
(-0.41)\end{array}$ & $\begin{array}{l}-0.007 \\
(-0.10)\end{array}$ & $\begin{array}{l}0.050 \\
(0.97)\end{array}$ & $\begin{array}{l}0.054 \\
(1.13)\end{array}$ \\
\hline Common currency & $\begin{array}{l}0.067 \\
(1.49)\end{array}$ & $\begin{array}{l}0.044 \\
(1.43)\end{array}$ & $\begin{array}{l}0.092 \\
(1.21)\end{array}$ & $\begin{array}{l}0.074 \\
(1.35)\end{array}$ & $\begin{array}{c}0.114^{+} \\
(1.66)\end{array}$ & $\begin{array}{c}0.124^{+} \\
(1.81)\end{array}$ \\
\hline Both in WTO & $\begin{array}{l}-0.096 \\
(-0.71)\end{array}$ & $\begin{array}{l}0.004 \\
(0.03)\end{array}$ & $\begin{array}{l}-0.040 \\
(-0.22)\end{array}$ & $\begin{array}{l}0.024 \\
(0.14)\end{array}$ & $\begin{array}{l}-0.154 \\
(-0.54)\end{array}$ & $\begin{array}{l}-0.129 \\
(-0.56)\end{array}$ \\
\hline Observations & $8,120,335$ & $32,162,466$ & $1,583,430$ & $3,329,109$ & $2,466,917$ & $3,069,076$ \\
\hline$R^{2}$ & 0.9837 & 0.9867 & 0.9730 & 0.9784 & 0.9926 & 0.9914 \\
\hline
\end{tabular}

Notes: $+{ }^{*},{ }^{* *}, * * *$ denote $10,5,1,0.1$ per cent significance levels, based on robust standard errors clustered by countrypair-product combinations.

${ }_{1}^{1}$ Regression includes importer-exporter-product, importer-product-time and exporter-product-time fixed effects.

2 Takes the value of "1" for intra-EU trade (after accession) of all countries that joined the EU after 1997. Analogously for US FTA. 
Table A2: Complete first-stage regression of Table 3

\begin{tabular}{|c|c|c|c|c|c|c|}
\hline \multirow{2}{*}{$\begin{array}{l}\text { Type of goods } \\
\text { Sample } \\
\text { Regression Set }\end{array}$} & \multicolumn{2}{|c|}{ All goods } & \multicolumn{2}{|c|}{ Intermediate } & \multicolumn{2}{|c|}{ Final } \\
\hline & $\begin{array}{l}\text { ICT } \\
(1)\end{array}$ & $\begin{array}{c}\text { Machinery } \\
\text { (2) }\end{array}$ & $\begin{array}{c}\text { ICT } \\
(3)\end{array}$ & $\begin{array}{l}\text { Machinery } \\
\text { (4) }\end{array}$ & $\begin{array}{l}\text { ICT } \\
(5)\end{array}$ & $\begin{array}{c}\text { Machinery } \\
\text { (6) }\end{array}$ \\
\hline \multicolumn{7}{|c|}{ Stage 1 (OLS). ${ }^{1}$ Dependent variable: bilateral share of products with positive imports in a sector } \\
\hline Exporter late EU signatory ${ }^{2}$ & $\begin{array}{c}0.020^{* * *} \\
(5.74)\end{array}$ & $\begin{array}{c}0.009^{* *} \\
(3.02)\end{array}$ & $\begin{array}{c}0.016^{* *} \\
(2.94)\end{array}$ & $\begin{array}{l}0.007 \\
(1.45)\end{array}$ & $\begin{array}{c}0.014^{* *} \\
(2.69)\end{array}$ & $\begin{array}{l}0.011^{*} \\
(2.38)\end{array}$ \\
\hline Exporter late US-FTA signatory ${ }^{2}$ & $\begin{array}{c}0.004 \\
(0.40)\end{array}$ & $\begin{array}{c}0.003 \\
(0.29)\end{array}$ & $\begin{array}{c}0.003 \\
(0.23)\end{array}$ & $\begin{array}{c}0.007 \\
(0.67)\end{array}$ & $\begin{array}{c}0.012 \\
(0.99)\end{array}$ & $\begin{array}{c}0.010 \\
(0.94)\end{array}$ \\
\hline RTA & $\begin{array}{c}0.009^{* * *} \\
(7.41)\end{array}$ & $\begin{array}{c}0.010^{* * *} \\
(8.82)\end{array}$ & $\begin{array}{c}-0.0002 \\
(-0.08)\end{array}$ & $\begin{array}{l}0.003 \\
(1.48)\end{array}$ & $\begin{array}{c}0.011^{* * *} \\
(5.95)\end{array}$ & $\begin{array}{c}0.011^{* * *} \\
(6.55)\end{array}$ \\
\hline Common currency & $\begin{array}{c}0.016^{* *} \\
(2.99)\end{array}$ & $\begin{array}{l}0.011^{*} \\
(2.12)\end{array}$ & $\begin{array}{c}0.021^{* * *} \\
(3.35)\end{array}$ & $\begin{array}{l}0.014^{*} \\
(2.19)\end{array}$ & $\begin{array}{c}0.029^{* * *} \\
(4.48)\end{array}$ & $\begin{array}{c}0.028^{* * *} \\
(4.61)\end{array}$ \\
\hline Both in WTO & $\begin{array}{l}0.003 \\
(1.00)\end{array}$ & $\begin{array}{c}0.007^{* *} \\
(3.03)\end{array}$ & $\begin{array}{l}0.001 \\
(0.23)\end{array}$ & $\begin{array}{c}0.007^{+} \\
(1.71)\end{array}$ & $\begin{array}{l}-0.005 \\
(-1.03)\end{array}$ & $\begin{array}{l}-0.004 \\
(-0.93)\end{array}$ \\
\hline Observations & 527,823 & 623,089 & 366,864 & 452,240 & 416,251 & 435,742 \\
\hline Adjusted $R^{2}$ & 0.9432 & 0.9487 & 0.9219 & 0.9241 & 0.9206 & 0.9232 \\
\hline
\end{tabular}

Notes: $+{ }^{*}, * *, * * *$ denote $10,5,1,0.1$ per cent significance levels, based on robust standard errors clustered by countrypair-product combinations.

1 Given the change in dependent variable, there is no meaningful way here - in contrast to Table 2 - to control for the impact of preferential tariff reductions in stage 1. Stage 1 includes importer-exporter-product, import-product-time and exporterproduct-time fixed effects.

2 Takes the value of "1" for intra-EU trade (after accession) of all countries that joined the EU after 1997 . Analogously for US FTA. 
Table A3: Complete first-stage regression of Table 5

\begin{tabular}{lcccccc}
\hline Type of goods & \multicolumn{7}{c}{ All goods } \\
\cline { 2 - 7 } Regression Set & $(1)$ & $(2)$ & $(3)$ & $(4)$ & $(5)$ & $(6)$ \\
\hline Stage 1 (PPML). ${ }^{1}$ Dependent variable: bilateral & product-level imports \\
\hline Preferential tariff reduction & $-1.150^{* * *}$ & $-0.472^{*}$ & $-0.808^{* *}$ & $-0.288^{+}$ & $-0.841^{* *}$ & $-0.308^{*}$ \\
& $(-3.66)$ & $(-2.03)$ & $(-2.85)$ & $(-1.76)$ & $(-2.92)$ & $(-2.04)$ \\
Preferential tariff reduction,t-1 & & & $-0.676^{*}$ & -0.294 & $-1.058^{* * *}$ & $-0.398^{* *}$ \\
& & & $(-2.15)$ & $(-1.43)$ & $(-3.78)$ & $(-2.63)$ \\
Preferential tariff reduction,t-2 & & & & & $0.822^{* *}$ & 0.240 \\
& & & & & $(2.88)$ & $(1.02)$ \\
Sum t to t-2 & $-1.150^{* * *}$ & $-0.472^{*}$ & $-1.484^{* *}$ & $-0.582+$ & $-1.077+$ & -0.466 \\
& $(-3.66)$ & $(-2.03)$ & $(-2.91)$ & $(-1.74)$ & $(-1.66)$ & $(-1.05)$ \\
Exporter late EU signatory ${ }^{2}$ & 0.081 & 0.068 & 0.065 & 0.057 & 0.089 & 0.065 \\
& $(0.83)$ & $(1.09)$ & $(0.65)$ & $(0.94)$ & $(0.88)$ & $(1.05)$ \\
Exporter late US-FTA signatory ${ }^{2}$ & -0.002 & -0.018 & 0.001 & -0.011 & -0.008 & -0.011 \\
& $(-0.03)$ & $(-0.38)$ & $(0.02)$ & $(-0.23)$ & $(-0.14)$ & $(-0.23)$ \\
RTA & 0.022 & 0.022 & 0.023 & 0.020 & 0.043 & 0.027 \\
& $(0.39)$ & $(0.50)$ & $(0.43)$ & $(0.49)$ & $(0.90)$ & $(0.71)$ \\
Common currency & 0.067 & 0.044 & 0.047 & 0.031 & 0.075 & 0.041 \\
Both in WTO & $(1.49)$ & $(1.43)$ & $(1.07)$ & $(1.03)$ & $(1.66)$ & $(1.33)$ \\
& -0.096 & 0.004 & -0.115 & -0.007 & -0.153 & -0.011 \\
$R^{2}$ & $(-0.71)$ & $(0.03)$ & $(-0.89)$ & $(-0.06)$ & $(-1.28)$ & $(-0.10)$ \\
& $8,120,335$ & $32,162,466$ & $7,232,615$ & $28,414,441$ & $6,697,866$ & $26,269,922$ \\
& 0.9837 & 0.9867 & 0.9840 & 0.9870 & 0.9842 & 0.9872 \\
\hline
\end{tabular}

Notes: $+{ }^{*},{ }^{* *}, * * *$ denote $10,5,1,0.1$ per cent significance levels, based on robust standard errors clustered by countrypair-product combinations.

${ }_{1}^{1}$ Regression includes importer-exporter-product, importer-product-time and exporter-product-time fixed effects.

2 Takes the value of "1" for intra-EU trade (after accession) of all countries that joined the EU after 1997. Analogously for US FTA. 
Table A4: Robustness: Analogue to Table 2 with positive trade values only

\begin{tabular}{|c|c|c|c|c|c|c|}
\hline \multirow{2}{*}{$\begin{array}{l}\text { Type of goods } \\
\text { Sample } \\
\text { Regression Set }\end{array}$} & \multicolumn{2}{|c|}{ All goods } & \multicolumn{2}{|c|}{ Intermediate } & \multicolumn{2}{|c|}{ Final } \\
\hline & $\begin{array}{c}\mathrm{ICT} \\
(1)\end{array}$ & $\begin{array}{l}\text { Machinery } \\
(2)\end{array}$ & $\begin{array}{c}\mathrm{ICT} \\
(3)\end{array}$ & $\begin{array}{c}\text { Machinery } \\
\text { (4) }\end{array}$ & $\begin{array}{c}\mathrm{ICT} \\
(5)\end{array}$ & $\begin{array}{l}\text { Machinery } \\
\text { (6) }\end{array}$ \\
\hline \multicolumn{7}{|c|}{ Stage 1 (PPML). ${ }^{1}$ Dependent variable: bilateral product-level imports } \\
\hline $\begin{array}{l}\text { Preferential tariff reduction } \\
\ln (1+\text { tariff })\end{array}$ & $\begin{array}{c}-1.083^{* * *} \\
(-3.40)\end{array}$ & $\begin{array}{r}-0.444^{+} \\
(-1.91)\end{array}$ & $\begin{array}{l}-1.614^{*} \\
(-2.34)\end{array}$ & $\begin{array}{l}-0.568 \\
(-1.62)\end{array}$ & $\begin{array}{l}-0.566 \\
(-1.45)\end{array}$ & $\begin{array}{l}-0.530 \\
(-1.14)\end{array}$ \\
\hline $\begin{array}{l}\text { Observations } \\
R^{2}\end{array}$ & $\begin{array}{c}5,635,912 \\
0.9838\end{array}$ & $\begin{array}{c}22,105,280 \\
0.9867\end{array}$ & $\begin{array}{c}1,100,335 \\
0.9731\end{array}$ & $\begin{array}{c}2,489,738 \\
0.9784\end{array}$ & $\begin{array}{c}1,683,823 \\
0.9926\end{array}$ & $\begin{array}{c}2,113,942 \\
0.9914\end{array}$ \\
\hline \multicolumn{7}{|c|}{ Stage 2 for importers (OLS). ${ }^{2}$ Dependent variable: importer-product-time FEs } \\
\hline MFN tariff reduction & $\begin{array}{l}-0.038 \\
(-0.23)\end{array}$ & $\begin{array}{c}-0.507^{* * *} \\
(-7.07)\end{array}$ & $\begin{array}{l}0.251 \\
(0.51)\end{array}$ & $\begin{array}{r}-0.497^{*} \\
(-2.09)\end{array}$ & $\begin{array}{l}-0.203 \\
(-0.67)\end{array}$ & $\begin{array}{l}0.076 \\
(0.40)\end{array}$ \\
\hline Tariff elimination effect & $\begin{array}{l}0.012 \\
(0.87)\end{array}$ & $\begin{array}{c}0.023^{* *} \\
(3.08)\end{array}$ & $\begin{array}{r}0.067^{+} \\
(1.83)\end{array}$ & $\begin{array}{r}0.052^{+} \\
(1.80)\end{array}$ & $\begin{array}{l}-0.056^{*} \\
(-2.36)\end{array}$ & $\begin{array}{l}-0.020 \\
(-0.88)\end{array}$ \\
\hline $\begin{array}{l}\text { Commitment effect: } \\
\text { active ITA importers }\end{array}$ & $\begin{array}{l}-0.024 \\
(-0.53)\end{array}$ & $\begin{array}{l}0.063^{+} \\
(1.74)\end{array}$ & $\begin{array}{l}0.063 \\
(0.59)\end{array}$ & $\begin{array}{l}0.129 \\
(1.62)\end{array}$ & $\begin{array}{l}0.120 \\
(1.43)\end{array}$ & $\begin{array}{l}0.076 \\
(0.94)\end{array}$ \\
\hline $\begin{array}{l}\text { Commitment effect: } \\
\text { passive ITA importers }\end{array}$ & $\begin{array}{c}0.117^{* * *} \\
(3.32)\end{array}$ & $\begin{array}{c}0.076^{* *} \\
(2.69)\end{array}$ & $\begin{array}{c}0.342^{* * *} \\
(3.78)\end{array}$ & $\begin{array}{c}0.196^{* *} \\
(2.87)\end{array}$ & $\begin{array}{l}0.033 \\
(0.56)\end{array}$ & $\begin{array}{l}0.047 \\
(0.83)\end{array}$ \\
\hline Observations & 367,521 & $1,729,821$ & 75,069 & 151,923 & 105,377 & 148,161 \\
\hline Adjusted $R^{2}$ & 0.8276 & 0.7908 & 0.8154 & 0.8445 & 0.8488 & 0.8229 \\
\hline \multicolumn{7}{|c|}{ Stage 2 for exporters (OLS). ${ }^{3}$ Dependent variable: exporter-product-time FEs } \\
\hline $\begin{array}{l}\text { Commitment effect: } \\
\text { active ITA exporters }\end{array}$ & $\begin{array}{l}0.080 \\
(1.48)\end{array}$ & $\begin{array}{l}0.026 \\
(0.62)\end{array}$ & $\begin{array}{l}0.152 \\
(1.02)\end{array}$ & $\begin{array}{l}0.083 \\
(0.73)\end{array}$ & $\begin{array}{l}0.027 \\
(0.30)\end{array}$ & $\begin{array}{l}0.041 \\
(0.49)\end{array}$ \\
\hline $\begin{array}{l}\text { Commitment effect: } \\
\text { passive ITA exporters }\end{array}$ & $\begin{array}{c}0.159^{* *} \\
(3.19)\end{array}$ & $\begin{array}{l}0.114^{* *} \\
(3.10)\end{array}$ & $\begin{array}{l}0.179 \\
(1.47)\end{array}$ & $\begin{array}{l}0.106 \\
(1.23)\end{array}$ & $\begin{array}{c}0.244^{* *} \\
(2.64)\end{array}$ & $\begin{array}{c}0.240^{* *} \\
(2.82)\end{array}$ \\
\hline $\begin{array}{l}\text { Commitment effect } \\
\text { other than } \text { China }^{4}\end{array}$ & $\begin{array}{r}0.098^{+} \\
(1.90)\end{array}$ & $\begin{array}{l}0.082^{*} \\
(2.14)\end{array}$ & $\begin{array}{l}0.122 \\
(0.95)\end{array}$ & $\begin{array}{l}0.108 \\
(1.18)\end{array}$ & $\begin{array}{r}0.173^{+} \\
(1.85)\end{array}$ & $\begin{array}{l}0.165^{*} \\
(1.96)\end{array}$ \\
\hline Observations & 335,896 & $1,389,361$ & 63,661 & 133,096 & 97,005 & 130,472 \\
\hline Adjusted $R^{2}$ & 0.7752 & 0.7473 & 0.7830 & 0.7756 & 0.7733 & 0.7633 \\
\hline
\end{tabular}

Notes: $+,{ }^{*}, * *, * * *$ denote $10,5,1,0.1$ per cent significance levels, based on robust standard errors clustered by country-pairproduct combinations in the first-stage regressions and by importer-product or exporter-product combinations, respectively, in the second-stage regressions.

1 Regression includes importer-exporter-product, import-product-time and exporter-product-time fixed effects.

Additionally, all first-stage regressions include a "Both in WTO" dummy, separate dummies for exports of late joiners of the EU and US FTAs covered under these agreements, and regional trade agreement and common currency dummies. Given the extensive fixed effect controls, the coefficients of these controls are insignificant; these results are available upon request.

2 Regression includes importer-time, importer-product and product-time fixed effects.

3 Regression includes exporter-time, exporter-product and product-time fixed effects.

4 These coefficients are obtained from an exact analog regression that excludes China's exports from the sample. The commitment effect for passive ITA exporters is the only one to substantially vary as a result of such a sample modification. The full regression results from this restricted sample are available upon request. 
Table A5: Robustness: Analogue to Table A4 with OLS estimation in first stage

\begin{tabular}{|c|c|c|c|c|c|c|}
\hline \multirow{2}{*}{$\begin{array}{l}\text { Type of goods } \\
\text { Sample } \\
\text { Regression Set }\end{array}$} & \multicolumn{2}{|c|}{ All goods } & \multicolumn{2}{|c|}{ Intermediate } & \multicolumn{2}{|c|}{ Final } \\
\hline & $\begin{array}{c}\mathrm{ICT} \\
(1)\end{array}$ & $\begin{array}{l}\text { Machinery } \\
(2)\end{array}$ & $\begin{array}{c}\mathrm{ICT} \\
(3)\end{array}$ & $\begin{array}{c}\text { Machinery } \\
\text { (4) }\end{array}$ & $\begin{array}{l}\mathrm{ICT} \\
(5)\end{array}$ & $\begin{array}{l}\text { Machinery } \\
\text { (6) }\end{array}$ \\
\hline \multicolumn{7}{|c|}{ Stage 1 (OLS). ${ }^{1}$ Dependent variable: bilateral product-level imports } \\
\hline $\begin{array}{l}\text { Preferential tariff reduction } \\
\ln (1+\text { tariff })\end{array}$ & $\begin{array}{c}-0.572^{* * *} \\
(-5.29)\end{array}$ & $\begin{array}{c}-0.293^{* * *} \\
(-6.22)\end{array}$ & $\begin{array}{c}-1.144^{* * *} \\
(-3.97)\end{array}$ & $\begin{array}{l}-0.276^{*} \\
(-2.00)\end{array}$ & $\begin{array}{l}-0.247 \\
(-1.29)\end{array}$ & $\begin{array}{l}-0.475^{* *} \\
(-2.94)\end{array}$ \\
\hline Observations & $5,207,713$ & $20,282,225$ & $1,023,268$ & $2,327,039$ & $1,565,702$ & $1,950,770$ \\
\hline Adjusted $R^{2}$ & 0.7695 & 0.7640 & 0.7859 & 0.7997 & 0.7633 & 0.7748 \\
\hline \multicolumn{7}{|c|}{ Stage 2 for importers $(\mathrm{OLS}) .^{2}$ Dependent variable: importer-product-time FEs } \\
\hline MFN tariff reduction & $\begin{array}{l}-0.323^{*} \\
(-2.41)\end{array}$ & $\begin{array}{c}-0.414^{* * *} \\
(-7.06)\end{array}$ & $\begin{array}{l}0.056 \\
(0.14)\end{array}$ & $\begin{array}{l}-0.298 \\
(-1.61)\end{array}$ & $\begin{array}{l}-0.182 \\
(-0.81)\end{array}$ & $\begin{array}{l}0.240 \\
(1.59)\end{array}$ \\
\hline Tariff elimination effect & $\begin{array}{l}0.025^{*} \\
(2.30)\end{array}$ & $\begin{array}{c}0.021^{* * *} \\
(3.73)\end{array}$ & $\begin{array}{c}0.091^{* * *} \\
(3.49)\end{array}$ & $\begin{array}{r}0.037^{+} \\
(1.85)\end{array}$ & $\begin{array}{l}-0.008 \\
(-0.41)\end{array}$ & $\begin{array}{l}0.002 \\
(0.08)\end{array}$ \\
\hline $\begin{array}{l}\text { Commitment effect: } \\
\text { active ITA importers }\end{array}$ & $\begin{array}{l}-0.057 \\
(-1.57)\end{array}$ & $\begin{array}{l}0.020 \\
(0.67)\end{array}$ & $\begin{array}{l}-0.062 \\
(-0.72)\end{array}$ & $\begin{array}{l}0.096 \\
(1.49)\end{array}$ & $\begin{array}{l}0.058 \\
(0.94)\end{array}$ & $\begin{array}{l}-0.003 \\
(-0.05)\end{array}$ \\
\hline $\begin{array}{l}\text { Commitment effect: } \\
\text { passive ITA importers }\end{array}$ & $\begin{array}{l}0.062^{*} \\
(2.18)\end{array}$ & $\begin{array}{l}0.023 \\
(1.00)\end{array}$ & $\begin{array}{l}0.145^{*} \\
(2.01)\end{array}$ & $\begin{array}{l}0.055 \\
(1.05)\end{array}$ & $\begin{array}{l}0.026 \\
(0.55)\end{array}$ & $\begin{array}{l}0.049 \\
(1.06)\end{array}$ \\
\hline Observations & 317,017 & $1,468,418$ & 61,991 & 132,276 & 94,644 & 130,233 \\
\hline Adjusted $R^{2}$ & 0.2085 & 0.1664 & 0.1794 & 0.2212 & 0.2317 & 0.2210 \\
\hline \multicolumn{7}{|c|}{ Stage 2 for exporters (OLS). ${ }^{3}$ Dependent variable: exporter-product-time FEs } \\
\hline $\begin{array}{l}\text { Commitment effect: } \\
\text { active ITA exporters }\end{array}$ & $\begin{array}{l}0.039 \\
(0.95)\end{array}$ & $\begin{array}{l}0.001 \\
(0.03)\end{array}$ & $\begin{array}{l}0.036 \\
(0.34)\end{array}$ & $\begin{array}{l}-0.037 \\
(-0.49)\end{array}$ & $\begin{array}{l}0.068 \\
(0.95)\end{array}$ & $\begin{array}{l}0.074 \\
(1.12)\end{array}$ \\
\hline $\begin{array}{l}\text { Commitment effect: } \\
\text { passive ITA exporters }\end{array}$ & $\begin{array}{l}0.061 \\
(1.42)\end{array}$ & $\begin{array}{l}0.050 \\
(1.56)\end{array}$ & $\begin{array}{l}-0.052 \\
(-0.47)\end{array}$ & $\begin{array}{l}-0.020 \\
(-0.29)\end{array}$ & $\begin{array}{c}0.231^{* *} \\
(2.92)\end{array}$ & $\begin{array}{c}0.226^{* *} \\
(3.10)\end{array}$ \\
\hline $\begin{array}{l}\text { Commitment effect } \\
\text { other than China }^{4}\end{array}$ & $\begin{array}{l}0.008 \\
(0.18)\end{array}$ & $\begin{array}{c}0.011 \\
(0.33)\end{array}$ & $\begin{array}{l}-0.187 \\
(-1.52)\end{array}$ & $\begin{array}{l}-0.057 \\
(-0.75)\end{array}$ & $\begin{array}{c}0.216^{* *} \\
(2.66)\end{array}$ & $\begin{array}{c}0.172^{*} \\
(2.34)\end{array}$ \\
\hline Observations & 220,154 & 904,298 & 42,524 & 89,570 & 63,401 & 84,377 \\
\hline Adjusted $R^{2}$ & 0.0752 & 0.0473 & 0.0899 & 0.1091 & 0.1008 & 0.0779 \\
\hline
\end{tabular}

Notes: $+,{ }^{*}, * *,{ }^{* * *}$ denote $10,5,1,0.1$ per cent significance levels, based on robust standard errors clustered by country-pairproduct combinations in the first-stage regressions and by importer-product or exporter-product combinations, respectively, in the second-stage regressions.

1 Regression includes importer-exporter-product, import-product-time and exporter-product-time fixed effects.

Additionally, all first-stage regressions include a "Both in WTO" dummy, separate dummies for exports of late joiners of the EU and US FTAs covered under these agreements, and regional trade agreement and common currency dummies. Given the extensive fixed effect controls, the coefficients of these controls are insignificant; these results are available upon request.

2 Regression includes importer-time, importer-product and product-time fixed effects.

3 Regression includes exporter-time, exporter-product and product-time fixed effects.

4 These coefficients are obtained from an exact analog regression that excludes China's exports from the sample. The commitment effect for passive ITA exporters is the only one to substantially vary as a result of such a sample modification. The full regression results from this restricted sample are available upon request. 
Table A6: Robustness: Analogue to Table 2 with sector-specific tariff effects

\begin{tabular}{|c|c|c|c|c|c|c|}
\hline \multirow{2}{*}{$\begin{array}{l}\text { Type of goods } \\
\text { Sample } \\
\text { Regression Set }\end{array}$} & \multicolumn{2}{|c|}{ All goods } & \multicolumn{2}{|c|}{ Intermediate } & \multicolumn{2}{|c|}{ Final } \\
\hline & $\begin{array}{c}\text { ICT } \\
(1)\end{array}$ & $\begin{array}{l}\text { Machinery } \\
\quad(2)\end{array}$ & $\begin{array}{c}\text { ICT } \\
(3)\end{array}$ & $\begin{array}{l}\text { Machinery } \\
\quad(4)\end{array}$ & $\begin{array}{c}\text { ICT } \\
(5)\end{array}$ & $\begin{array}{l}\text { Machinery } \\
\text { (6) }\end{array}$ \\
\hline \multicolumn{7}{|c|}{ Stage 1 (PPML). ${ }^{1}$ Dependent variable: bilateral product-level imports } \\
\hline $\begin{array}{l}\text { Preferential tariff reduction: } \\
\text { ITA goods }\end{array}$ & $\begin{array}{c}-1.252^{* *} \\
(-2.59)\end{array}$ & $\begin{array}{l}-1.258^{* *} \\
(-2.61)\end{array}$ & $\begin{array}{l}-1.966^{*} \\
(-2.05)\end{array}$ & $\begin{array}{l}-2.172^{*} \\
(-2.30)\end{array}$ & $\begin{array}{l}-0.419 \\
(-0.42)\end{array}$ & $\begin{array}{l}-0.315 \\
(-0.31)\end{array}$ \\
\hline $\begin{array}{l}\text { Preferential tariff reduction: } \\
\text { other goods }\end{array}$ & $\begin{array}{l}-1.035^{*} \\
(-2.42)\end{array}$ & $\begin{array}{l}-0.425 \\
(-1.58)\end{array}$ & $\begin{array}{l}-1.374 \\
(-1.48)\end{array}$ & $\begin{array}{l}-0.334 \\
(-0.91)\end{array}$ & $\begin{array}{l}-0.638 \\
(-1.59)\end{array}$ & $\begin{array}{l}-0.605 \\
(-1.20)\end{array}$ \\
\hline Observations & $8,120,335$ & $32,162,466$ & $1,583,430$ & $3,329,109$ & $2,466,917$ & $3,069,076$ \\
\hline$R^{2}$ & 0.9837 & 0.9867 & 0.9730 & 0.9784 & 0.9926 & 0.9914 \\
\hline \multicolumn{7}{|c|}{ Stage 2 for importers $(\mathrm{OLS}) .^{2}$ Dependent variable: importer-product-time FEs } \\
\hline $\begin{array}{l}\text { MFN tariff reduction: } \\
\text { ITA goods }\end{array}$ & $\begin{array}{l}0.042 \\
(0.18)\end{array}$ & $\begin{array}{l}0.293 \\
(1.39)\end{array}$ & $\begin{array}{l}0.588 \\
(0.93)\end{array}$ & $\begin{array}{c}1.735^{* * *} \\
(3.44)\end{array}$ & $\begin{array}{l}-0.713 \\
(-1.43)\end{array}$ & $\begin{array}{l}-0.526 \\
(-1.09)\end{array}$ \\
\hline $\begin{array}{l}\text { MFN tariff reduction: } \\
\text { other goods }\end{array}$ & $\begin{array}{l}-0.452^{*} \\
(-2.10)\end{array}$ & $\begin{array}{c}-0.742^{* * *} \\
(-9.17)\end{array}$ & $\begin{array}{r}-1.246^{+} \\
(-1.95)\end{array}$ & $\begin{array}{c}-1.213^{* * *} \\
(-4.30)\end{array}$ & $\begin{array}{l}-0.450 \\
(-1.24)\end{array}$ & $\begin{array}{l}0.083 \\
(0.40)\end{array}$ \\
\hline $\begin{array}{l}\text { Tariff elimination effect: } \\
\text { ITA goods }\end{array}$ & $\begin{array}{r}0.033^{+} \\
(1.83)\end{array}$ & $\begin{array}{c}0.031^{+} \\
(1.82)\end{array}$ & $\begin{array}{l}0.089^{*} \\
(2.10)\end{array}$ & $\begin{array}{l}0.094^{*} \\
(2.47)\end{array}$ & $\begin{array}{l}-0.075^{*} \\
(-2.24)\end{array}$ & $\begin{array}{r}-0.064^{+} \\
(-1.92)\end{array}$ \\
\hline $\begin{array}{l}\text { Tariff elimination effect: } \\
\text { other goods }\end{array}$ & $\begin{array}{c}0.122^{* * *} \\
(4.54)\end{array}$ & $\begin{array}{l}0.146^{* * *} \\
(15.79)\end{array}$ & $\begin{array}{c}0.386^{* * *} \\
(4.69)\end{array}$ & $\begin{array}{c}0.213^{* * *} \\
(4.35)\end{array}$ & $\begin{array}{l}0.031 \\
(0.83)\end{array}$ & $\begin{array}{c}0.140^{* * *} \\
(3.96)\end{array}$ \\
\hline $\begin{array}{l}\text { Commitment effect: } \\
\text { active ITA importers }\end{array}$ & $\begin{array}{l}-0.007 \\
(-0.13)\end{array}$ & $\begin{array}{l}0.048 \\
(1.22)\end{array}$ & $\begin{array}{l}0.103 \\
(0.89)\end{array}$ & $\begin{array}{r}0.168^{+} \\
(1.95)\end{array}$ & $\begin{array}{l}0.196^{*} \\
(2.24)\end{array}$ & $\begin{array}{l}0.115 \\
(1.37)\end{array}$ \\
\hline $\begin{array}{l}\text { Commitment effect: } \\
\text { passive ITA importers }\end{array}$ & $\begin{array}{c}0.141^{* * *} \\
(3.64)\end{array}$ & $\begin{array}{c}0.085^{* *} \\
(2.73)\end{array}$ & $\begin{array}{c}0.505^{* * *} \\
(5.10)\end{array}$ & $\begin{array}{c}0.252^{* * *} \\
(3.45)\end{array}$ & $\begin{array}{l}0.078 \\
(1.19)\end{array}$ & $\begin{array}{r}0.114^{+} \\
(1.82)\end{array}$ \\
\hline Observations & 367,521 & $1,729,821$ & 75,069 & 151,923 & 105,377 & 148,161 \\
\hline Adjusted $R^{2}$ & 0.8334 & 0.7984 & 0.8260 & 0.8496 & 0.8548 & 0.8302 \\
\hline \multicolumn{7}{|c|}{ Stage 2 for exporters (OLS). ${ }^{3}$ Dependent variable: exporter-product-time FEs } \\
\hline $\begin{array}{l}\text { Commitment effect: } \\
\text { active ITA exporters }\end{array}$ & $\begin{array}{l}0.004 \\
(0.05)\end{array}$ & $\begin{array}{l}-0.051 \\
(-1.00)\end{array}$ & $\begin{array}{l}-0.006 \\
(-0.03)\end{array}$ & $\begin{array}{l}0.092 \\
(0.63)\end{array}$ & $\begin{array}{l}-0.157 \\
(-1.46)\end{array}$ & $\begin{array}{l}-0.034 \\
(-0.35)\end{array}$ \\
\hline $\begin{array}{l}\text { Commitment effect: } \\
\text { passive ITA exporters }\end{array}$ & $\begin{array}{c}0.156^{* *} \\
(2.70)\end{array}$ & $\begin{array}{c}0.212^{* * *} \\
(4.91)\end{array}$ & $\begin{array}{l}0.208 \\
(1.41)\end{array}$ & $\begin{array}{r}0.188^{+} \\
(1.89)\end{array}$ & $\begin{array}{l}0.229^{*} \\
(2.18)\end{array}$ & $\begin{array}{c}0.333^{* * *} \\
(3.52)\end{array}$ \\
\hline $\begin{array}{l}\text { Commitment effect } \\
\text { other than China }{ }^{4}\end{array}$ & $\begin{array}{l}0.126^{*} \\
(2.06)\end{array}$ & $\begin{array}{l}0.218^{* * *} \\
(4.80)\end{array}$ & $\begin{array}{l}0.174 \\
(1.13)\end{array}$ & $\begin{array}{r}0.202^{+} \\
(1.92)\end{array}$ & $\begin{array}{r}0.198^{+} \\
(1.80)\end{array}$ & $\begin{array}{c}0.306^{* *} \\
(3.23)\end{array}$ \\
\hline Observations & 335,896 &, 361 & 63,661 & 133,096 & 97,005 & 130,472 \\
\hline Adjusted $R^{2}$ & 0.7335 & 0.6980 & 0.7496 & 0.7391 & 0.7232 & 0.7225 \\
\hline
\end{tabular}

Notes: $+{ }^{*}, * *,^{* * *}$ denote $10,5,1,0.1$ per cent significance levels, based on robust standard errors clustered by country-pair-product combinations in the first-stage regressions and by importer-product or exporter-product combinations, respectively, in the second-stage regressions.

${ }^{1}$ Regression includes importer-exporter-product, importer-product-time and exporter-product-time fixed effects. Additionally, all first-stage regressions include a "Both in WTO" dummy, separate dummies for exports of late joiners of the EU and US FTAs covered under these agreements, and regional trade agreement and common currency dummies. Given the extensive fixed effect controls, the coefficients of these controls are insignificant; these results are available upon request.

2 Regression includes importer-time, importer-product and product-time fixed effects.

3 Regression includes exporter-time, exporter-product and product-time fixed effects.

4 These coefficients are obtained from an exact analog regression that excludes China's exports from the sample. The commitment effect for passive ITA exporters is the only one to substantially vary as a result of such a sample modification. The full regression results from this restricted sample are available upon request. 
Table A7: Robustness: Analogue to Table 2 excluding China's exports

\begin{tabular}{|c|c|c|c|c|c|c|}
\hline \multirow{2}{*}{$\begin{array}{l}\text { Type of goods } \\
\text { Sample } \\
\text { Regression Set }\end{array}$} & \multicolumn{2}{|c|}{ All goods } & \multicolumn{2}{|c|}{ Intermediate } & \multicolumn{2}{|c|}{ Final } \\
\hline & $\begin{array}{l}\mathrm{ICT} \\
(1)\end{array}$ & $\begin{array}{l}\text { Machinery } \\
\quad(2)\end{array}$ & $\begin{array}{l}\mathrm{ICT} \\
(3)\end{array}$ & $\begin{array}{l}\text { Machinery } \\
\text { (4) }\end{array}$ & $\begin{array}{l}\mathrm{ICT} \\
(5)\end{array}$ & $\begin{array}{l}\text { Machinery } \\
\text { (6) }\end{array}$ \\
\hline \multicolumn{7}{|c|}{ Stage 1 (PPML). ${ }^{1}$ Dependent variable: bilateral product-level imports } \\
\hline Preferential tariff reduction & $\begin{array}{c}-1.060^{* *} \\
(-3.11)\end{array}$ & $\begin{array}{l}-0.460 \\
(-1.81)\end{array}$ & $\begin{array}{l}-1.324 \\
(-1.95)\end{array}$ & $\begin{array}{l}-0.399 \\
(-1.17)\end{array}$ & $\begin{array}{l}-0.599 \\
(-1.42)\end{array}$ & $\begin{array}{l}-0.624 \\
(-1.29)\end{array}$ \\
\hline Observations & $7,854,306$ & $30,991,385$ & $1,531,220$ & $3,224,329$ & $2,385,817$ & $2,962,625$ \\
\hline$R^{2}$ & 0.9790 & 0.9855 & 0.9558 & 0.9735 & 0.9779 & 0.9900 \\
\hline \multicolumn{7}{|c|}{ Stage 2 for importers $(\mathrm{OLS}) .^{2}$ Dependent variable: importer-product-time FEs } \\
\hline MFN tariff reduction & $\begin{array}{l}-0.406^{*} \\
(-2.23)\end{array}$ & $\begin{array}{c}-0.648^{* * *} \\
(-8.33)\end{array}$ & $\begin{array}{l}-0.686 \\
(-1.25)\end{array}$ & $\begin{array}{c}-0.803^{* *} \\
(-3.16)\end{array}$ & $\begin{array}{l}-0.774^{*} \\
(-2.49)\end{array}$ & $\begin{array}{c}-0.0699 \\
(-0.35)\end{array}$ \\
\hline Tariff elimination effect & $\begin{array}{c}0.0716^{* * *} \\
\quad(4.54)\end{array}$ & $\begin{array}{c}0.126^{* * *} \\
(15.36)\end{array}$ & $\begin{array}{c}0.160^{* * *} \\
(4.00)\end{array}$ & $\begin{array}{c}0.119^{* * *} \\
(3.80)\end{array}$ & $\begin{array}{c}0.0246 \\
(0.94)\end{array}$ & $\begin{array}{c}0.0855^{* * *} \\
(3.45)\end{array}$ \\
\hline $\begin{array}{l}\text { Commitment effect: } \\
\text { active ITA importers }\end{array}$ & $\begin{array}{c}-0.00952 \\
(-0.19)\end{array}$ & $\begin{array}{l}0.0565 \\
(1.45)\end{array}$ & $\begin{array}{l}0.0288 \\
(0.25)\end{array}$ & $\begin{array}{l}0.132 \\
(1.53)\end{array}$ & $\begin{array}{c}0.286^{* *} \\
(3.19)\end{array}$ & $\begin{array}{l}0.197^{*} \\
(2.33)\end{array}$ \\
\hline $\begin{array}{l}\text { Commitment effect: } \\
\text { passive ITA importers }\end{array}$ & $\begin{array}{c}0.0947^{*} \\
(2.40)\end{array}$ & $\begin{array}{c}0.0442 \\
(1.40)\end{array}$ & $\begin{array}{c}0.424^{* * *} \\
(4.29)\end{array}$ & $\begin{array}{l}0.201^{* *} \\
(2.77)\end{array}$ & $\begin{array}{c}-0.0136 \\
(-0.20)\end{array}$ & $\begin{array}{c}0.0253 \\
(0.39)\end{array}$ \\
\hline Observations & 364,525 & $1,714,610$ & 74,378 & 150,971 & 104,543 & 146,773 \\
\hline Adjusted $R^{2}$ & 0.8208 & 0.7908 & 0.8213 & 0.8464 & 0.8327 & 0.8146 \\
\hline \multicolumn{7}{|c|}{ Stage 2 for exporters (OLS). ${ }^{3}$ Dependent variable: exporter-product-time FEs } \\
\hline $\begin{array}{l}\text { Commitment effect: } \\
\text { active ITA exporters }\end{array}$ & $\begin{array}{r}-0.0127 \\
(-0.20)\end{array}$ & $\begin{array}{c}-0.0494 \\
(-1.00)\end{array}$ & $\begin{array}{l}0.00413 \\
(0.02)\end{array}$ & $\begin{array}{c}0.0844 \\
(0.59)\end{array}$ & $\begin{array}{l}-0.148 \\
(-1.39)\end{array}$ & $\begin{array}{c}-0.0120 \\
(-0.13)\end{array}$ \\
\hline $\begin{array}{l}\text { Commitment effect: } \\
\text { passive ITA exporters }\end{array}$ & $\begin{array}{l}0.126^{*} \\
(2.06)\end{array}$ & $\begin{array}{c}0.216^{* * *} \\
(4.82)\end{array}$ & $\begin{array}{l}0.173 \\
(1.13)\end{array}$ & $\begin{array}{l}0.202 \\
(1.94)\end{array}$ & $\begin{array}{l}0.198 \\
(1.80)\end{array}$ & $\begin{array}{c}0.303^{* *} \\
(3.15)\end{array}$ \\
\hline Observations & 332,426 & $1,373,696$ & 62,947 & 131,758 & 96,137 & 129,233 \\
\hline Adjusted $R^{2}$ & 0.7281 & 0.6979 & 0.7469 & 0.7366 & 0.7119 & 0.7174 \\
\hline
\end{tabular}

Notes: $+,{ }^{*}, * *,{ }^{* *}$ denote 10, 5, 1, 0.1 per cent significance levels, based on robust standard errors clustered by country-pairproduct combinations in the first-stage regressions and by importer-product or exporter-product combinations, respectively, in the second-stage regressions.

${ }^{1}$ Regression includes importer-exporter-product, import-product-time and exporter-product-time fixed effects.

Additionally, all first-stage regressions include a "Both in WTO" dummy, separate dummies for exports of late joiners of the EU and US FTAs covered under these agreements, and regional trade agreement and common currency dummies. Given the extensive fixed effect controls, the coefficients of these controls are insignificant; these results are available upon request.

${ }^{2}$ Regression includes importer-time, importer-product and product-time fixed effects.

${ }^{3}$ Regression includes exporter-time, exporter-product and product-time fixed effects.

4 These coefficients are obtained from an exact analog regression that excludes China's exports from the sample. The commitment effect for passive ITA exporters is the only one to substantially vary as a result of such a sample modification.

The full regression results from this restricted sample are available upon request. 
Table A8: Robustness: Analogue to Table 2 excluding country pairs with RTAs by 1996

\begin{tabular}{|c|c|c|c|c|c|c|}
\hline \multirow{2}{*}{$\begin{array}{l}\text { Type of goods } \\
\text { Sample } \\
\text { Regression Set }\end{array}$} & \multicolumn{2}{|c|}{ All goods } & \multicolumn{2}{|c|}{ Intermediate } & \multicolumn{2}{|c|}{ Final } \\
\hline & $\begin{array}{l}\mathrm{ICT} \\
(1)\end{array}$ & $\begin{array}{l}\text { Machinery } \\
\quad(2)\end{array}$ & $\begin{array}{l}\text { ICT } \\
(3)\end{array}$ & $\begin{array}{l}\text { Machinery } \\
\text { (4) }\end{array}$ & $\begin{array}{l}\mathrm{ICT} \\
(5)\end{array}$ & $\begin{array}{l}\text { Machinery } \\
\text { (6) }\end{array}$ \\
\hline \multicolumn{7}{|c|}{ Stage 1 (PPML). ${ }^{1}$ Dependent variable: bilateral product-level imports } \\
\hline Preferential tariff reduction & $\begin{array}{r}-1.062^{+} \\
(-1.84)\end{array}$ & $\begin{array}{l}-0.457 \\
(-1.28)\end{array}$ & $\begin{array}{l}-1.734 \\
(-1.33)\end{array}$ & $\begin{array}{l}-0.497 \\
(-0.69)\end{array}$ & $\begin{array}{l}-0.806 \\
(-1.31)\end{array}$ & $\begin{array}{l}-0.866 \\
(-1.18)\end{array}$ \\
\hline Observations & $5,701,870$ & $2,250,1666$ & $1,106,049$ & $2,372,692$ & $1,742,614$ & $2,190,899$ \\
\hline$R^{2}$ & 0.9881 & 0.9891 & 0.9768 & 0.9771 & 0.9951 & 0.9933 \\
\hline \multicolumn{7}{|c|}{ Stage 2 for importers $(\mathrm{OLS}) .^{2}$ Dependent variable: importer-product-time FEs } \\
\hline MFN tariff reduction & $\begin{array}{l}-0.222 \\
(-1.17)\end{array}$ & $\begin{array}{c}-0.714^{* * *} \\
(-8.66)\end{array}$ & $\begin{array}{l}-0.077 \\
(-0.14)\end{array}$ & $\begin{array}{l}-0.616^{*} \\
(-2.23)\end{array}$ & $\begin{array}{l}-0.174 \\
(-0.54)\end{array}$ & $\begin{array}{c}0.383^{+} \\
(1.94)\end{array}$ \\
\hline Tariff elimination effect & $\begin{array}{c}0.047^{* *} \\
(2.79)\end{array}$ & $\begin{array}{c}0.122^{* * *} \\
(13.54)\end{array}$ & $\begin{array}{c}0.153^{* * *} \\
(3.53)\end{array}$ & $\begin{array}{c}0.130^{* * *} \\
(3.86)\end{array}$ & $\begin{array}{c}-0.048^{+} \\
(-1.67)\end{array}$ & $\begin{array}{c}0.049^{+} \\
(1.82)\end{array}$ \\
\hline $\begin{array}{l}\text { Commitment effect: } \\
\text { active ITA importers }\end{array}$ & $\begin{array}{l}-0.017 \\
(-0.34)\end{array}$ & $\begin{array}{l}0.003 \\
(0.08)\end{array}$ & $\begin{array}{l}0.125 \\
(1.07)\end{array}$ & $\begin{array}{l}0.200^{*} \\
(2.30)\end{array}$ & $\begin{array}{l}0.126 \\
(1.38)\end{array}$ & $\begin{array}{l}0.042 \\
(0.48)\end{array}$ \\
\hline $\begin{array}{l}\text { Commitment effect: } \\
\text { passive ITA importers }\end{array}$ & $\begin{array}{l}0.121^{* *} \\
(2.94)\end{array}$ & $\begin{array}{l}0.091^{* *} \\
(2.71)\end{array}$ & $\begin{array}{c}0.430^{* * *} \\
(4.11)\end{array}$ & $\begin{array}{l}0.206^{* *} \\
(2.64)\end{array}$ & $\begin{array}{l}0.007 \\
(0.10)\end{array}$ & $\begin{array}{l}0.066 \\
(0.99)\end{array}$ \\
\hline Obsel & 348,656 & $1,629,802$ & 70,679 & 144,657 & 100,847 & 141,432 \\
\hline Adjusted $R^{2}$ & 0.8254 & 0.7868 & 0.8211 & 0.8432 & 0.8431 & 0.8188 \\
\hline \multicolumn{7}{|c|}{ Stage 2 for exporters $(\mathrm{OLS}) .{ }^{3}$ Dependent variable: exporter-product-time FEs } \\
\hline $\begin{array}{l}\text { Commitment effect: } \\
\text { active ITA exporters }\end{array}$ & $\begin{array}{l}-0.034 \\
(-0.53)\end{array}$ & $\begin{array}{l}-0.072 \\
(-1.42)\end{array}$ & $\begin{array}{l}-0.012 \\
(-0.07)\end{array}$ & $\begin{array}{l}-0.011 \\
(-0.08)\end{array}$ & $\begin{array}{l}-0.145 \\
(-1.42)\end{array}$ & $\begin{array}{l}-0.092 \\
(-0.97)\end{array}$ \\
\hline $\begin{array}{l}\text { Commitment effect: } \\
\text { passive ITA exporters }\end{array}$ & $\begin{array}{l}0.124^{*} \\
(2.04)\end{array}$ & $\begin{array}{c}0.158^{* * *} \\
(3.48)\end{array}$ & $\begin{array}{l}0.144 \\
(0.97)\end{array}$ & $\begin{array}{l}0.156 \\
(1.50)\end{array}$ & $\begin{array}{l}0.258^{*} \\
(2.27)\end{array}$ & $\begin{array}{c}0.362^{* * *} \\
(3.49)\end{array}$ \\
\hline Observations & 279,417 & $1,136,040$ & 53,096 & 111,123 & 80,994 & 109,302 \\
\hline Adjusted $R^{2}$ & 0.8018 & 0.7495 & 0.7965 & 0.7890 & 0.8102 & 0.7850 \\
\hline
\end{tabular}

Notes: $+,{ }^{*}, * *, * *$ denote 10,5,1, 0.1 per cent significance levels, based on robust standard errors clustered by country-pairproduct combinations in the first-stage regressions and by importer-product or exporterr-product combinations, respectively, in the second-stage regressions.

${ }^{1}$ Regression includes importer-exporter-product, import-product-time and exporter-product-time fixed effects. Additionally, all first-stage regressions include a "Both in WTO" dummy, separate dummies for exports of late joiners of the EU and US FTAs covered under these agreements, and regional trade agreement and common currency dummies. Given the extensive fixed effect controls, the coefficients of these controls are insignificant; these results are available upon request.

${ }^{2}$ Regression includes importer-time, importer-product and product-time fixed effects.

${ }^{3}$ Regression includes exporter-time, exporter-product and product-time fixed effects. 


\section{Table A9: Extension: Heterogeneity of ITA commitment effects on exports}

\begin{tabular}{|c|c|c|c|c|c|}
\hline \multicolumn{6}{|c|}{ Stage 2 for exporters (OLS). ${ }^{1}$ Dependent variable: exporter-product-time FEs } \\
\hline Interaction Variable: & None $^{2}$ & Remoteness $^{2}$ & Education ${ }^{2}$ & Business environment $^{2}$ & Rule of law ${ }^{2}$ \\
\hline Active ITA Exporter & $\begin{array}{l}0.003 \\
(0.05)\end{array}$ & $\begin{array}{l}0.102 \\
(1.27)\end{array}$ & $\begin{array}{l}0.201^{*} \\
(1.97)\end{array}$ & $\begin{array}{l}0.087 \\
(1.11)\end{array}$ & $\begin{array}{l}0.134 \\
(1.56)\end{array}$ \\
\hline $\begin{array}{l}\text { Active ITA Exporter } \\
* \text { Interaction Variable }\end{array}$ & & $\begin{array}{l}0.037^{*} \\
(2.13)\end{array}$ & $\begin{array}{l}-0.063^{*} \\
(-2.23)\end{array}$ & $\begin{array}{c}-0.110^{* *} \\
(-3.11)\end{array}$ & $\begin{array}{c}-0.167^{* *} \\
(-3.27)\end{array}$ \\
\hline Passive ITA Exporter & $\begin{array}{c}0.157^{* *} \\
(2.70)\end{array}$ & $\begin{array}{l}0.103 \\
(1.18)\end{array}$ & $\begin{array}{l}0.199 \\
(1.43)\end{array}$ & $\begin{array}{l}0.150^{*} \\
(2.54)\end{array}$ & $\begin{array}{l}0.142^{*} \\
(2.44)\end{array}$ \\
\hline $\begin{array}{l}\text { Passive ITA Exporters } \\
* \text { Interaction Variable }\end{array}$ & & $\begin{array}{l}-0.021 \\
(-0.76)\end{array}$ & $\begin{array}{l}-0.026 \\
(-0.66)\end{array}$ & $\begin{array}{l}0.041 \\
(0.47)\end{array}$ & $\begin{array}{l}0.009 \\
(0.12)\end{array}$ \\
\hline $\begin{array}{l}\text { Observations } \\
\text { Adjusted } R^{2}\end{array}$ & $\begin{array}{c}335,896 \\
0.7336\end{array}$ & $\begin{array}{c}330,137 \\
0.7322\end{array}$ & $\begin{array}{c}243,187 \\
0.7288\end{array}$ & $\begin{array}{c}323,254 \\
0.7277\end{array}$ & $\begin{array}{c}323,936 \\
0.7283\end{array}$ \\
\hline \multicolumn{6}{|c|}{$\begin{array}{l}\text { Memorandum item: } \\
\text { Interaction variable values in } 2010 \text { by percentile for passive ITA signatories }{ }^{3}\end{array}$} \\
\hline $\begin{array}{l}10 \text { th } \\
25 \text { th } \\
50 \text { th } \\
75 \text { th } \\
90 \text { th }\end{array}$ & & $\begin{array}{c}-3.766 \\
-3.560 \\
-2.864 \\
0.520 \\
0.910\end{array}$ & $\begin{array}{l}1.607 \\
1.652 \\
2.870 \\
4.048 \\
4.604\end{array}$ & $\begin{array}{c}-0.773 \\
-0.628 \\
-0.352 \\
0.249 \\
0.854\end{array}$ & $\begin{array}{c}-0.885 \\
-0.600 \\
-0.329 \\
0.480 \\
0.982\end{array}$ \\
\hline
\end{tabular}

Notes: Stage 1 regression is the same as in Regression 1 of Table 2.

$+, *, * *, * *$ denote 10, 5, 1, 0.1 per cent significance levels, based on robust standard errors clustered by country-pairproduct combinations in the first-stage regressions and by importer-product or exporter-product combinations, respectively, in the second-stage regressions. The figures in Table 6 are computed from percentile-specific interaction variable values and coefficients for passive signatories. For example, the 0.162 value for the 50 th percentile in the "Remoteness" column is obtained by $0.103+(-0.021)^{*}(-2.864)$, where 0.103 is the passive ITA exporter dummy, -0.021 is the coefficient on the interaction of this dummy with remoteness, and -2.864 is the median value of the remoteness variable. Significance levels in Table 6 are computed using the Delta method.

1 Regression includes exporter-time, exporter-product and product-time fixed effects.

${ }^{2}$ Remoteness is measured as sum over importers in any given year of Distance ijt*(ITA Imports it/ITA World Imports t). For landlocked countries only, this is then multiplied by a year-specific multiplier of (cost of exporting a container in $\mathrm{j}$ )/(cost of exporting a container in nearest coastal country). The data on the cost of exporting a container are from the World Bank's Doing Business Indicators database. Distance is measured in thousands of kilometers and centered around its mean. Therefore the coefficient on the interaction displays how much the benefit of joining the ITA changes for a country that is $1000 \mathrm{~km}$ further removed from import hubs than the average country.

Education is proxied by the secondary school completion rate (Prati et al, 2013). This completion rate is divided by 10 , so that the interaction coefficient depicts the effect of increasing completion rates by 10 percentage points.

Business environment is proxied by the control of corruption variable of the World Bank's World Governance Indicators. Breen and Gillanders (2010) demonstrate that control of corruption is a good approximation for the quality of the overall business environment.

Rule of law variable is taken from the World Bank's World Governance Indicators.

3 These percentile values for 2010 are used in the computations in Table 6 and were calculated based on the sample of passive signatories only. 
Table A10: Extension: Interaction of tariff reduction and tariff elimination effects

\begin{tabular}{|c|c|c|c|c|c|c|}
\hline \multirow{2}{*}{$\begin{array}{l}\text { Type of goods } \\
\text { Sample } \\
\text { Regression Set }\end{array}$} & \multicolumn{2}{|c|}{ All goods } & \multicolumn{2}{|c|}{ Intermediate } & \multicolumn{2}{|c|}{ Final } \\
\hline & $\begin{array}{c}\mathrm{ICT} \\
(1)\end{array}$ & $\begin{array}{c}\text { Machinery } \\
\text { (2) }\end{array}$ & $\begin{array}{c}\mathrm{ICT} \\
(3)\end{array}$ & $\begin{array}{c}\text { Machinery } \\
\text { (4) }\end{array}$ & $\begin{array}{c}\mathrm{ICT} \\
(5)\end{array}$ & $\begin{array}{c}\text { Machinery } \\
\text { (6) }\end{array}$ \\
\hline \multicolumn{7}{|c|}{ Stage 1 (PPML). ${ }^{1}$ Dependent variable: bilateral product-level imports } \\
\hline \multicolumn{7}{|c|}{ Stage 1 regressions are the same as in Table 2.} \\
\hline \multicolumn{7}{|c|}{ Stage 2 for importers $(\mathrm{OLS}) .^{2}$ Dependent variable: importer-product-time FEs } \\
\hline MFN tariff reduction & $\begin{array}{l}-0.262 \\
(-1.39)\end{array}$ & $\begin{array}{c}-0.769^{* * *} \\
(-9.26)\end{array}$ & $\begin{array}{l}-0.838 \\
(-1.51)\end{array}$ & $\begin{array}{c}-0.882^{* *} \\
(-3.07)\end{array}$ & $\begin{array}{c}-0.718^{*} \\
(-2.11)\end{array}$ & $\begin{array}{l}-0.252 \\
(-1.17)\end{array}$ \\
\hline Tariff elimination effect & $\begin{array}{c}0.0612^{* *} \\
(3.07)\end{array}$ & $\begin{array}{c}0.121^{* * *} \\
(12.17)\end{array}$ & $\begin{array}{c}0.136^{* *} \\
(2.74)\end{array}$ & $\begin{array}{c}0.106^{* *} \\
(2.88)\end{array}$ & $\begin{array}{l}-0.012 \\
(-0.37)\end{array}$ & $\begin{array}{l}0.068^{*} \\
(2.24)\end{array}$ \\
\hline Tariff reduction $\mathrm{x}$ elimination effect & $\begin{array}{l}-0.247 \\
(-0.78)\end{array}$ & $\begin{array}{c}-0.572^{* * *} \\
(-3.76)\end{array}$ & $\begin{array}{l}-0.049 \\
(-0.07)\end{array}$ & $\begin{array}{l}-0.165 \\
(-0.35)\end{array}$ & $\begin{array}{l}-0.240 \\
(-0.46)\end{array}$ & $\begin{array}{l}-0.501 \\
(-1.24)\end{array}$ \\
\hline Observations & 304,034 & $1,466,540$ & 61,180 & 132,314 & 86,944 & 124,603 \\
\hline Adjusted $R^{2}$ & 0.8274 & 0.8028 & 0.8145 & 0.8475 & 0.8522 & 0.8273 \\
\hline
\end{tabular}

Notes: $+{ }^{*}, * *, * * *$ denote $10,5,1,0.1$ per cent significance levels, based on robust standard errors clustered by countrypair-product combinations in the first-stage regressions and by importer-product or importer-product combinations in the second-stage regressions.

1 Regression includes importer-exporter-product, importer-product-time and exporter-product-time fixed effects. Additionally, all first-stage regressions include a "Both in WTO" dummy, separate dummies for exports of late joiners of the EU and US FTAs covered under these agreements, and regional trade agreement and common currency dummies. Given the extensive fixed effect controls, the coefficients of these controls are insignificant; these results are in Table A1.

2 Regression includes importer-time, importer-product and product-time fixed effects.

Table A11: Average share of products trade with bilateral partners

\begin{tabular}{|c|c|c|c|c|c|c|c|c|c|}
\hline \multirow{2}{*}{$\begin{array}{l}\text { Type of goods } \\
\text { Sample }^{1}\end{array}$} & \multicolumn{3}{|c|}{ All goods } & \multicolumn{3}{|c|}{ Intermediate } & \multicolumn{3}{|c|}{ Final } \\
\hline & ITA & $\mathrm{ICT}$ & Machinery & ITA & ICT & Machinery & ITA & ICT & Machinery \\
\hline Active ITA imp & 0.15 & 0.13 & 0.10 & 0.21 & 0.16 & 0.16 & 0.22 & 0.18 & 0.15 \\
\hline Active ITA importers in 2012 & 0.16 & 0.14 & 0.09 & 0.25 & 0.18 & 0.14 & 0.25 & 0.22 & 0.18 \\
\hline Active ITA exporters in 1996 & 0.21 & 0.20 & 0.15 & 0.29 & 0.23 & 0.23 & 0.34 & 0.28 & 0.22 \\
\hline Active ITA exporters in 2012 & 0.25 & 0.22 & 0.15 & 0.38 & 0.25 & 0.21 & 0.39 & 0.36 & 0.28 \\
\hline Passive ITA importers in 1996 & 0.17 & 0.16 & 0.11 & 0.24 & 0.19 & 0.20 & 0.30 & 0.24 & 0.19 \\
\hline Passive ITA importers in 2012 & 0.14 & 0.11 & 0.07 & 0.20 & 0.13 & 0.11 & 0.21 & 0.19 & 0.15 \\
\hline Passive ITA exporters in 1996 & 0.08 & 0.07 & 0.04 & 0.13 & 0.09 & 0.09 & 0.15 & 0.11 & 0.08 \\
\hline Passive ITA exporters in 2012 & 0.13 & 0.11 & 0.06 & 0.21 & 0.14 & 0.11 & 0.24 & 0.19 & 0.14 \\
\hline
\end{tabular}

Notes: This table presents the average share of products traded with bilateral partners, i.e. these are the sample means by product categories of the dependent variable in the first stage of Table 3 . For instance, a value of 0.20 for ITA products implies that 20 percent of all ITA products exhibit positive trade, while 80 percent exhibit zero trade flows.

${ }^{1}$ In this table, ICT (Machinery) refers to non-ITA ICT goods (non-ITA Machinery goods), unlike in our regression tables. 


\section{Appendix Figures}

Figure A1: ITA product exports in the year previous to accession (percent of GDP)
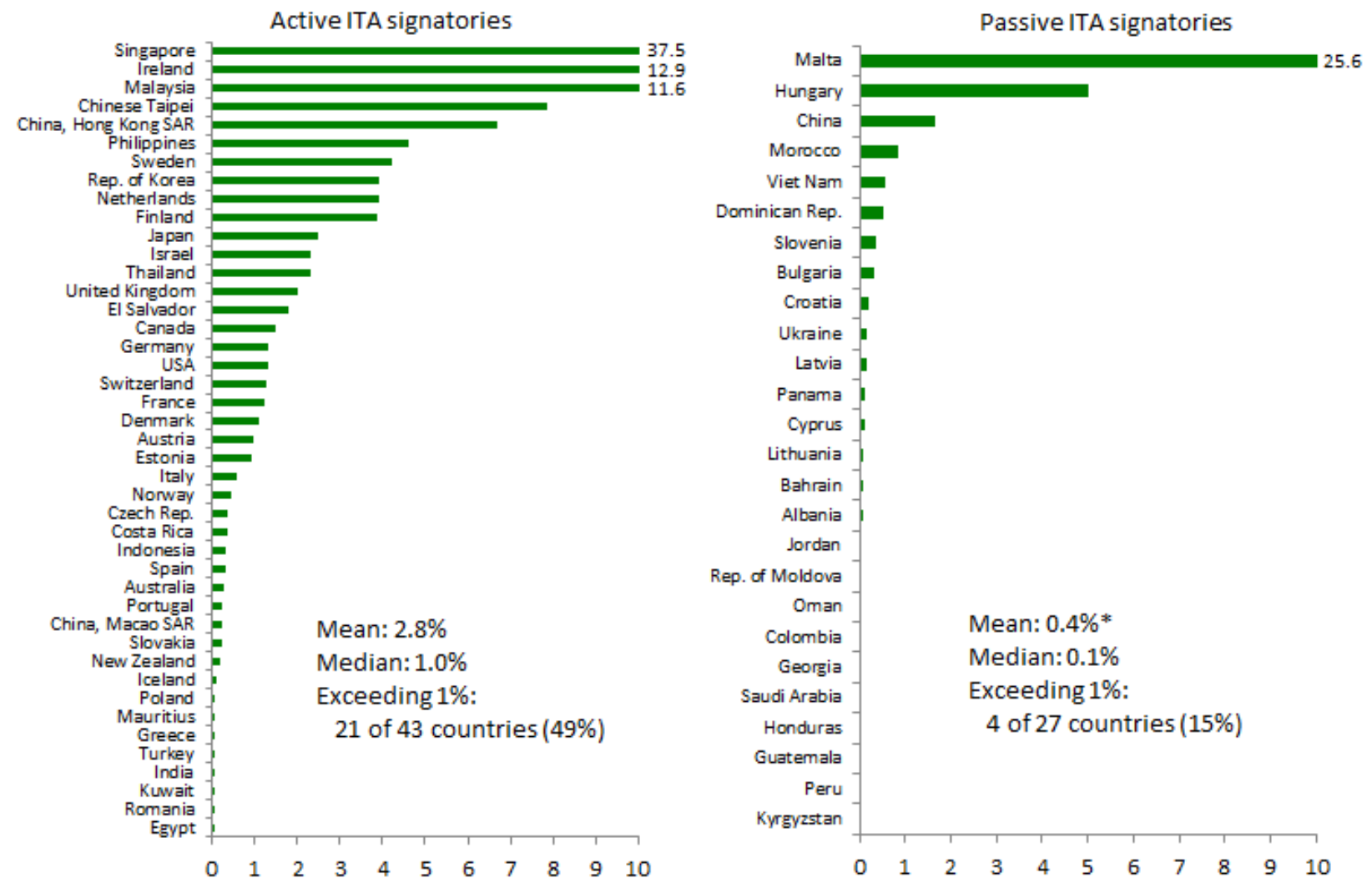

- Excludes Malta, because its value is driven by a sing le heritage semiconductor factory. 
Figure A2: ITA product share in a country's total exports in the year previous to accession
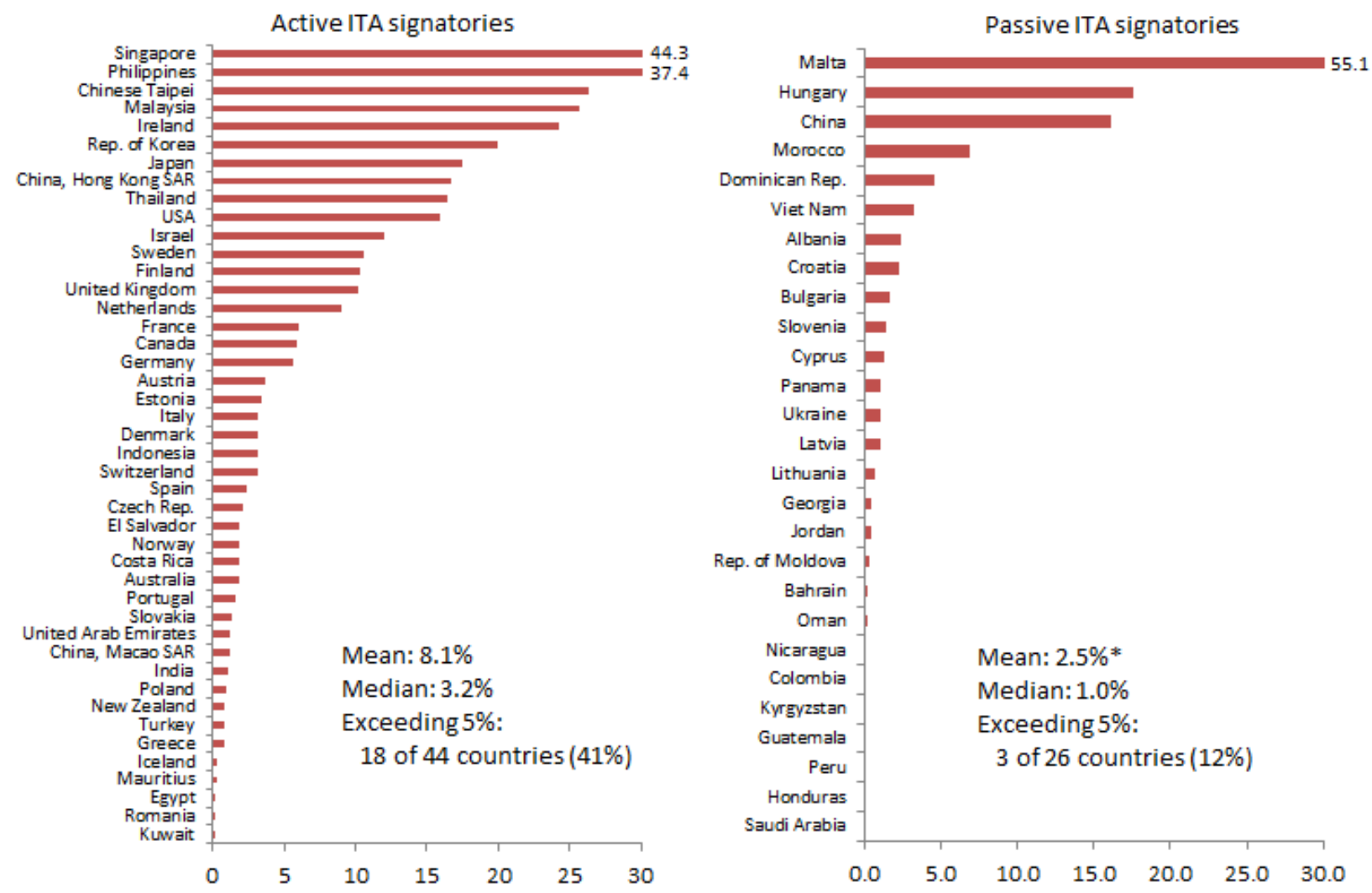

- Excludes Malta, because its va lue is driven by a sing le heritage semiconductor factory. 


\section{Data Appendix}

Our dataset matches product-level trade data in ITA products to tariffs, ITA membership and common gravity variables. These are discussed in turn, but first we elaborate further on the empirical issues posed by the ITA's aforementioned complex product coverage.

The ITA contains a rigid positive listing of covered products which reaches across categories in the 6-digit HS1996 classification on which the agreement was signed: In total, it affects 154 product lines in this classification, but only 95 product lines are covered fully. The rest are covered partially, creating an issue for empirical analysis, as also highlighted by Anderson and Mohs (2010). We thus consider as ITA products in our analysis all fully covered lines plus another 11 lines, which according to World Trade Organization (WTO) (2012) include a high proportion of ITA products, for a total of 106 lines.

This problem relating to the ITA's coverage becomes further amplified in later years by the updates to the HS2002 and HS2007 vintages. Consequently, its coverage has to be reassessed in each of the vintages instead of being simply mapped. For instance, a given tariff line may have covered a lot of ITA products (relative to non-ITA products), when trade was reported in the HS1996 vintage, and it therefore was considered an ITA product line. However, in latter years, this line may not be considered an ITA tariff line any more due to the shift to HS2007 reporting. The reason is changing trade structure: Now relatively more non-ITA products may be traded under this line as a result of some ITA products having become technologically obsolete. Thus, the lines that we consider to be covered by the ITA vary between vintages. We therefore first obtain separate lists of the product lines covered by the ITA during 1996-2001 in HS1996, 2002-06 in HS2002 and 2007-12 in HS2007.

In a next step, we then map the HS2002 and HS2007 lines into HS1996 using conversion tables from the UN Statistics Division (UNSD) website to obtain a consistent HS1996-based dataset. The HS2002 lines map into the exact same set of lines that we also obtained for HS1996 because the updates in classification methodology were minor between these two vintages. But this is not the case for HS2007, so that our resulting dataset contains a different number of tariff lines during the time periods 1996-2006 and 2007-12: 23 (9) HS1996 lines appear only during the former (latter) period, while 74 HS1996 lines are included in all years, thereby resulting in our abovementioned total of 106 lines.

With this set of ITA-related HS1996 lines on hand, we can then obtain 6-digit HS1996 bilateral trade flow data for 1996-2012 from UN Comtrade. We use the import flow data and complement with exporter-reported mirror data. ${ }^{1}$ This gives us 3.86 million observations of non-zero ITA trade flows covering 234 countries, though not all observations are useable in all regressions in light of missing values for tariffs.

These data on tariffs are obtained from UN Trains in HSCombined for the years 19962012. This reporting in HSCombined (rather than HS1996 throughout as in Comtrade) makes necessary an additional step. HSCombined gives tariffs for 1996-2001 in HS1996, 2002-06 in

\footnotetext{
${ }^{1}$ We apply the mirror data whenever a certain import-reporter did not report for the particular year at all. We restrict the mirror data to such cases only, because if a country reports bilateral trade in the particular year, but doesn't specify some line or it is zero while it is present in the mirror data, then there is not actually a lack of reporting issue but a difference in methodology of classifying products between importer and exporter.
} 
HS2002 and 2007-12 in HS2007. We therefore again employ the conversion tables to generate tariffs for our set of HS1996 lines throughout all years. ${ }^{2}$ To fill in some missing observations, we then linearly intrapolate tariffs between years for which observations exist. ${ }^{3}$

As further right-hand side variables, we collect any standard gravity variables which vary across time within any country or country-pair. ${ }^{4}$ GDP and GDP per capita were taken from Penn World Table Version 8.0. RTA and currency union membership data are taken from De Sousa (2012). ${ }^{5}$ A remoteness measure was computed analogue to those commonly used in the literature. ${ }^{6}$ WTO membership data was collected from the WTO website.

Sturgeon and Memedovic (2010) emphasize the importance of intermediate goods to understanding global value chains. They develop a novel classification scheme, classifying product lines for different sectors into those primarily including final or intermediate goods. ${ }^{7}$ This is helpful for us to analyze how ITA membership effects differ between countries in different positions in value chains - upstream (exporting intermediates) and downstream (importing intermediates/exporting final goods). The authors provide such a classification for electronics goods on HS2007 basis, which we use to split our sample to investigate how the ITA effects may operate through GVCs. ${ }^{8}$ When converted to HS1996 using the UNSD conversion tables, we find this classification to cover 47 of our 106 ITA product lines. ${ }^{9}$

ITA products can be classified in 7 broad product categories, as outlined in World Trade Organization (WTO) (2012). We resort to these to reduce the dimensionality of our dataset in our robustness check for zero trade flows which use non-linear Poisson estimation. The categories are the following (with number of 6-digit HS1996 lines included in parentheses): Computers (14), Instruments and apparatus (17), Parts and accessories (32), Semiconductor

\footnotetext{
${ }^{2}$ We use the conversion table for conversion of HS2007 and HS2002 to HS1996. If there are multiple HS2007 or HS2002 lines corresponding to a HS1996 line in our list, we take a simple average across thes HS2007 or HS2002 lines to obtain the tariff for the HS1996 line.

${ }^{3}$ Furthermore we had to take into account that the EU is presented as a single country in TRAINS. Thus we appended the dataset to include all its members in various years to achieve cons istent coverage of active signatories throughout the sample period.

${ }^{4}$ Non-time variant variables such as distance are controlled for by importer-exporter(-product) fixed effects in all our specifications.

${ }^{5}$ De Sousa (2012) data only cover currency union relationships up to 2009. To extend the data, we added Estonia joining the Euro in 2011. As we are not aware of any other countries joining or exiting a currency union after 2009 and before 2013, we assume that no further changes in currency union membership occurred after this time. Like the Glick and Rose (2002) currency union definition, ours is also transitive, i.e. if country-pairs $\mathrm{x}-\mathrm{y}$, and $\mathrm{x}-\mathrm{z}$ are in currency unions, then $\mathrm{y}-\mathrm{z}$ is a currency union. Therefore with both El Salvador and Ecuador having adopted the U.S. Dollar, they would both be considered to be in a currency union with the United States as well as each other.

${ }^{6}$ Our remoteness measure is computed for importers and exporters using the standard formula, weighting bilateral distances by trading partner shares in world GDP (see e.g. UNCTAD and WTO, 2012). To obtain a single remoteness measures for any bilateral pair in the interest of parsimony, importer and exporter remoteness are then multiplied before taking the natural logarithm.

${ }^{7}$ Their classification could has become part of the fourth revision of the BEC classification, which distinguishes between customized intermediate goods (typically relating to trade within global value chains) and other intermediate goods.

${ }^{8}$ These data on HS2007 basis were kindly provided to us by the authors. Sturgeon and Memedovic (2010) include analogs on SITC and ISIC basis.

${ }^{9}$ When the ICT (machinery) control sector is added 102 of 202 (165 of 995) lines are covered by the classification.
} 
manufacturing equipment (10), Semiconductors (15), Data-storage media and software (9) and Telecommunications equipment (9). Computers, semiconductors, and parts and accessories are the most traded products, making up around 80 percent of ITA product trade flows.

In many of our regressions, we use control sectors help us assess how ITA trade has performed relative to that of comparable goods post ITA accession. We use two of such control sectors: other information and communications technology (ICT) goods, not covered by the ITA, and machinery goods.

For ICT goods, the OECD provides a definition which covers a total of 193 product lines in the 6-digit HS1996 classification. ${ }^{10}$ Of these 193 lines, 77 are also covered by the ITA under our definition of 106 lines. Thus non-ITA ICT goods - the control sector - comprise 116 lines and add another 3.70 million observations to the dataset. ${ }^{11}$ Meanwhile, 29 lines are covered by the ITA that are not considered ICT goods by the OECD. ${ }^{12}$

Finally, we also construct a broad machinery control sector. We select HS sections 84, 85, 87, and 90. These comprise electrical and non-electrical machinery, road vehicles and optical/photographic/precision instruments and were chosen because these sectors also tend to be quite integrated in GVCs. This broad machinery sector comprises all ITA and ICT tariff lines. ${ }^{13}$. Its inclusion brings our dataset to a total of 28.36 million observations.

\section{References}

Anderson, M., Mohs, J., 2010. The Information Technology Agreement: An Assessment of World Trade in Information Technology Products. Journal of International Commerce and Economics 3, 109-154.

De Sousa, J., 2012. The currency union effect on trade is decreasing over time. Economics Letters 117 (3), 917-920.

Glick, R., Rose, A. K., 2002. Does a currency union affect trade? The time-series evidence. European Economic Review 46 (6), 1125-1151.

Organisation for Economic Co-operation and Development, 2003. A proposed classification of ICT goods. OECD Working Party on Indicators for the Information Society, OECD, Paris.

\footnotetext{
${ }^{10}$ This coverage results when we combine the Organisation for Economic Co-operation and Development (2003) and the updated Organisation for Economic Co-operation and Development (2011) definitions to achieve a broad definition of ICT goods across time.

${ }^{11}$ In addition, product lines that are covered by the ITA for instance only in 2007-12 are considered control sector lines during 1996-2006, if covered by the OECD ICT definition.

${ }^{12}$ These 29 lines cover manifold products, mainly printing machinery, electric typewriters and optical photocopiers; laser discs and magnetic tapes; electric and power capacitators; equipment for measuri ng liquid or gas; and parts of accessories of aforementioned products.

${ }^{13}$ To be exact, two ITA tariff lines (HS 381800: Chemical element/compound wafers doped for electronics; HS 950410: Video games used with the TV receiver) are not covered by the four HS sections, but remain in the dataset throughout.
} 
Organisation for Economic Co-operation and Development, 2011. OECD Guide to Measuring the Information Society 2011. Paris: OECD Publishing.

Sturgeon, T. J., Memedovic, O., 2010. Mapping global value chains: Intermediate goods trade and structural change in the world economy. Working Paper No. 05/2010, United Nations Industrial Development Organization.

UNCTAD and WTO, 2012. A Practical Guide to Trade Policy Analysis. United Nations Conference on Trade and Development/World Trade Organisation.

World Trade Organization (WTO), 2012. 15 Years of the Information Technology Agreement. Report, World Trade Organization. 